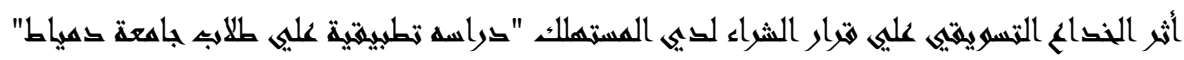

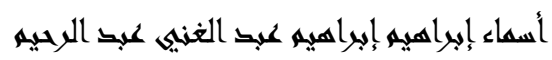

$$
\begin{aligned}
& \text { أثر الخداع التسويفي علي قرار الثراء لاي المستهليك }
\end{aligned}
$$

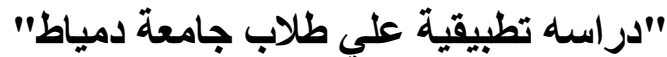

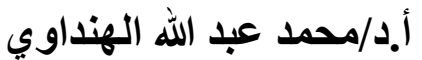

$$
\begin{aligned}
& \text { أستاذ إدارة الأعمال } \\
& \text { ورئيس قسم إدارة الأعمال كلية التجارة ـجامعة دمياط } \\
& \text { الباحثه } \\
& \text { أسماء إبراهيم إبراهيم عبد الغني عبد الرحيم }
\end{aligned}
$$

استهدف هذا البحث قياس أثز الخداع التسويقي علي قرار الثراء للمستهلك دراسة تطبيقية علي طلاب جامعة دمياط المتعاملين مع مطاعم الوجبات السريعه

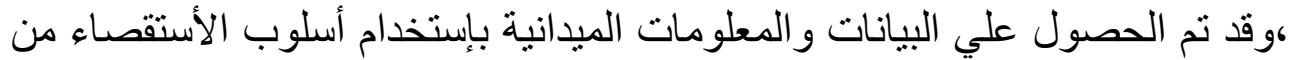

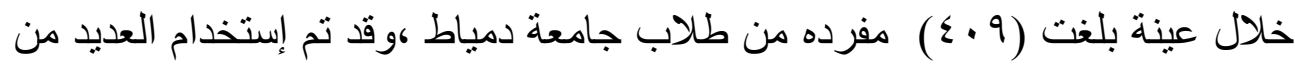

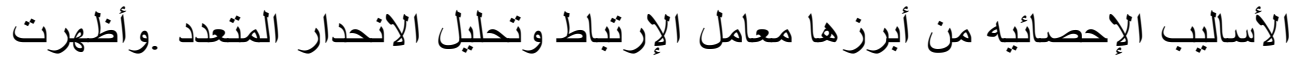

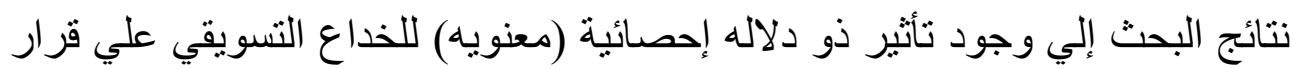
الثر اءه

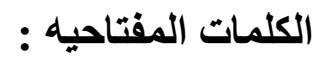
الخداع التسويقي ،الخداع في المنتج ،الخداع في السعر ،الخداع في التوزيع ،الخداع في الترويج ، قرار الثراء

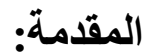

يعتبر التسويق أحد أهم الأنشطة التي تقوم بها المنظمة، ويعد التسويق أمر بالغ الأهمية لنجاح الأعمال وتحقيق الأهداف للمنظمة (kotlar,2016). و التسويق التئة الفعال

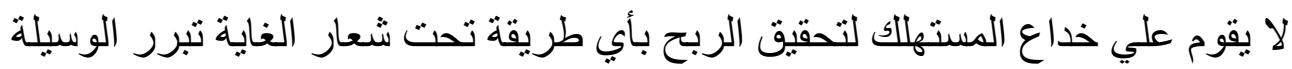

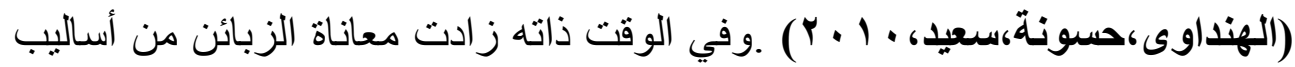

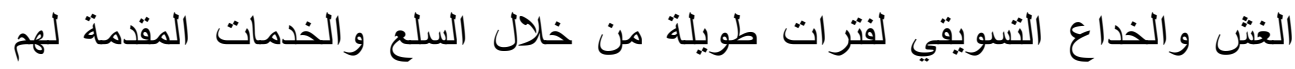

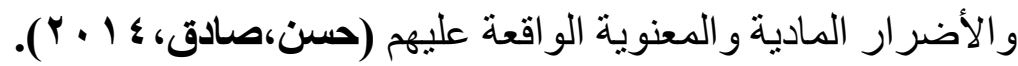




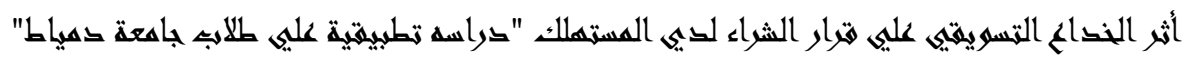

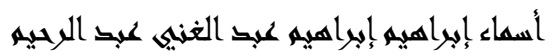

وفي ظل الإقتصاد العالمي وما يتصف به من كثرة المنافسة و التقدم التكنولوجي وكثرة البدائل أمام المستهلك يعد حافزاً للعديد من الشركات للممارسات الغات من الغير أخلاقية ومن بينها ما تمارسه المنظمات من خداع وغش في النشاط التسويقي للنأثير علي

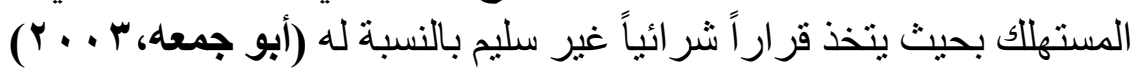

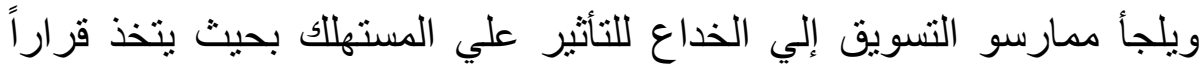

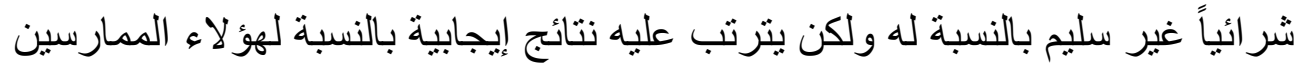

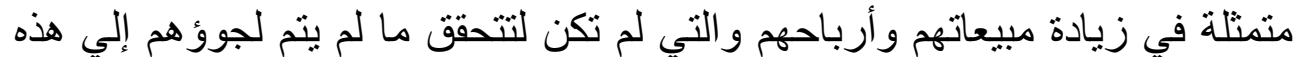

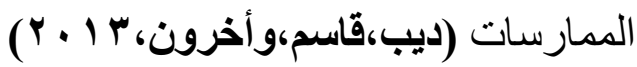

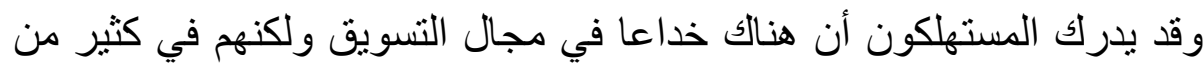

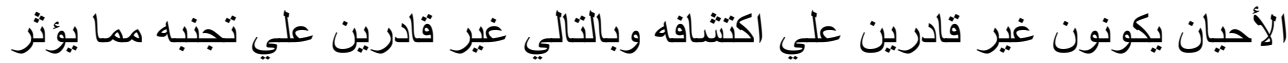

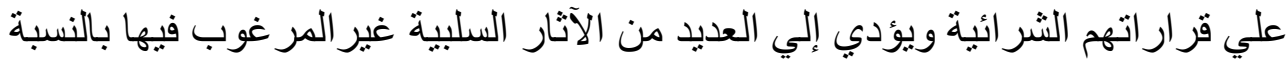

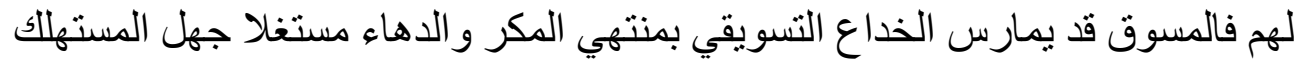
وقلة معرفته وقد يجري ذلك بشكل خفي لا بدركه المستهلك ويصعب وفي اكتشافه في

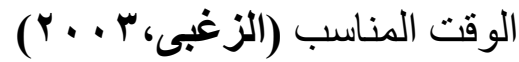
وتعد ممارسة منظمات الأعمال للخداع التسويقي أن تقوم الثركة بتوصيل

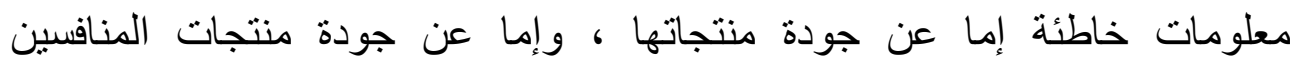
.(Durkin,s.,2014)

كما يعتبر الخداع التسويقي احتيالاً وغنشاً، بهدف تحقيق كسب غير مشروع علي

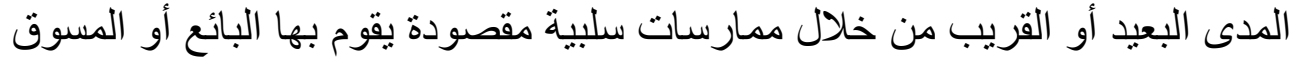
في سبيل الحصول علي منفعة ما بغض النظر عن النتائج المنرنبة علي الزبون الزبون

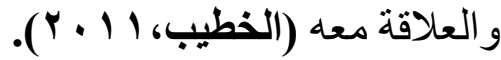
و الخداع التسويقي تزداد أهميته في ظل موجة الغلاء الكبيرة التي تشهدها العديد

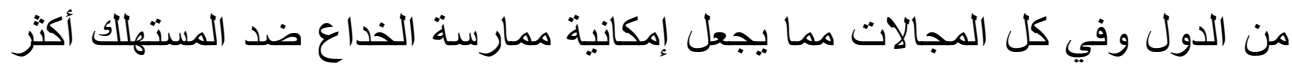

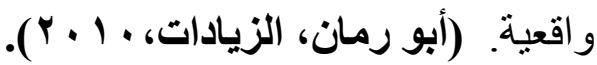
ولللك فيعد الخداع التسويقي أية ممارسة تسويقية يترتب عليهان الزيها تكوين إنطباع أو 


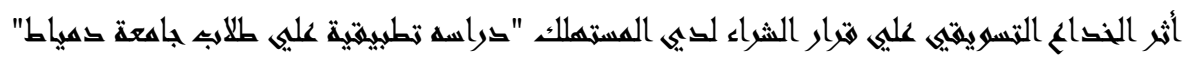

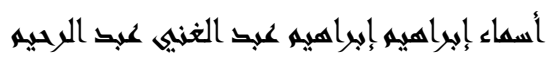

إعتقاد أو تقدير شخصي خاطئ لدي المستهلك فيما يتعلق بالثئ موضع التسويق

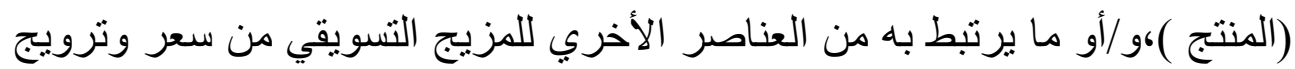

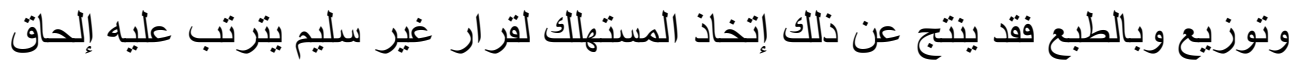

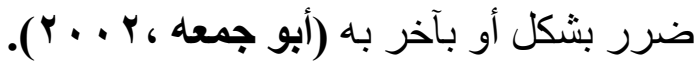

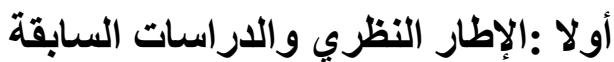

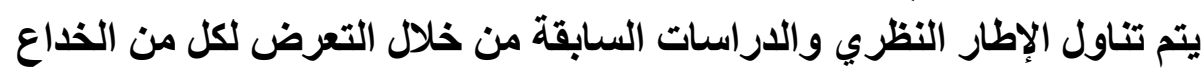

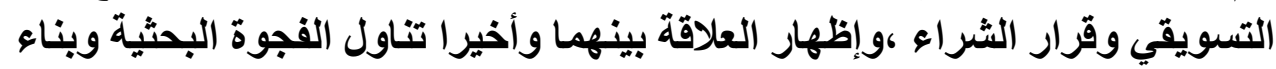

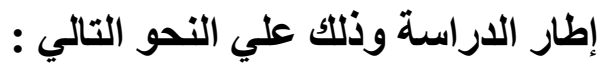

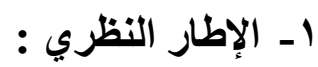

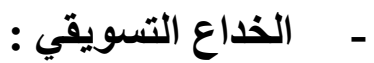

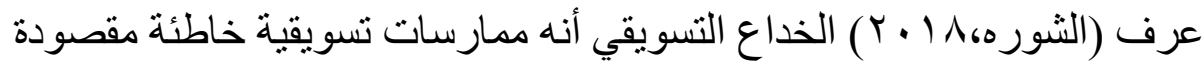
أو غير مقصودة يترتب عليها تضليل الزبون و إتخاذه قرارات شرائية يترتب علئ عليها تكوين إنطباع سلبي ، كما عرفه (Al-zyadat,2017) أنه سلوك غير فير أخلافي بين

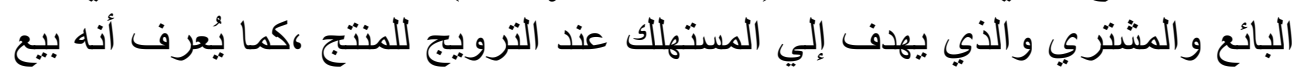
المنتجات بشكل غير أخلاقي وبطريقة لا تحترم المستهلك وذلك بخداعه وبسعر غير بـاج مناسب للمنتج (Aladwan,Hersh,2014) .ويعرفه (saeed,et al.,2013) أنه وفئه ممارسات مضللة وتحريف مقصود يقع علي المستهلك وذللك بتحقيق منفعة أقل من

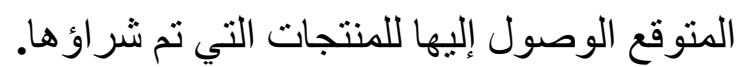
- مرار الشراء: -

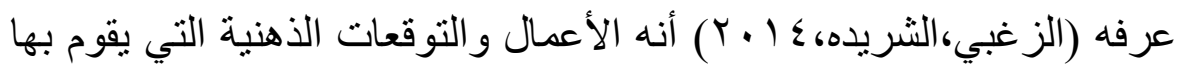
المستهلكين عند ظهور الضرورة أو الرغبة في الثراء ،كما عرفها عرفه (الرحيمي،

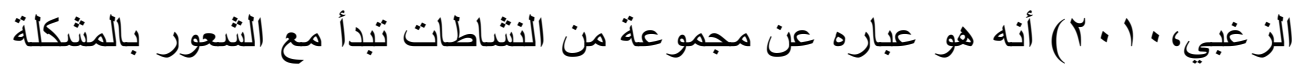

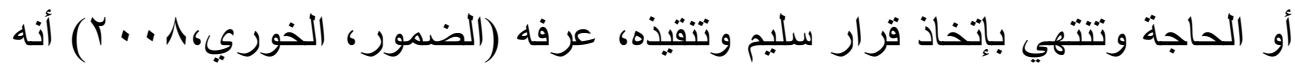

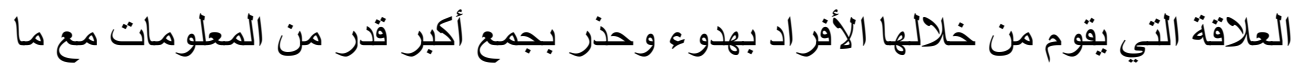
يعرفونه سابقا عن السلعة ويبذلون جهدهم في تقييم مز ايا وسلبيات كل بديل من البدائل 


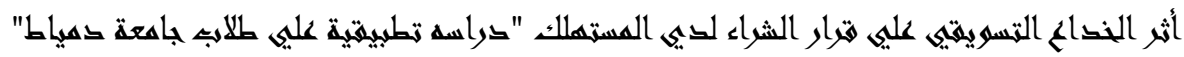

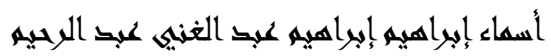

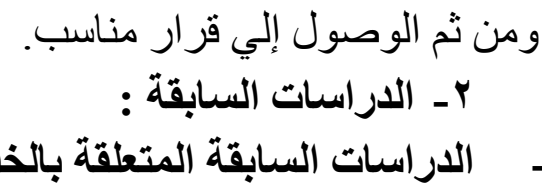

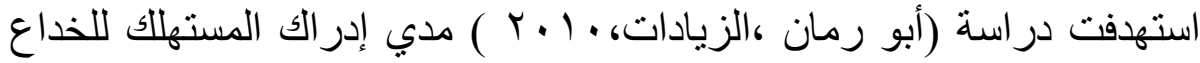

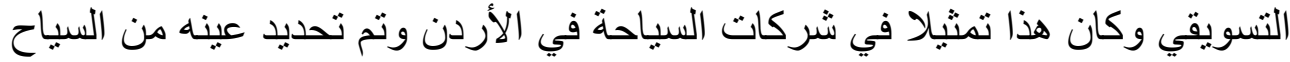

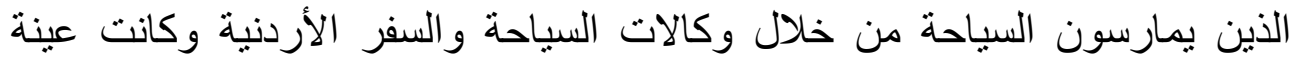

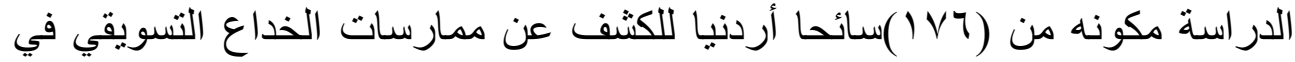

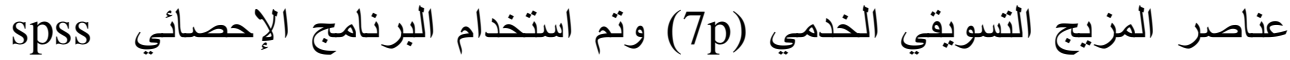

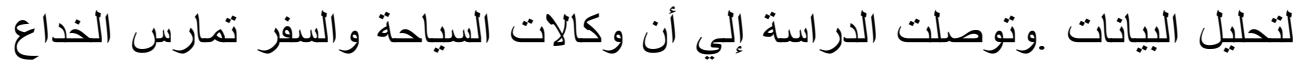

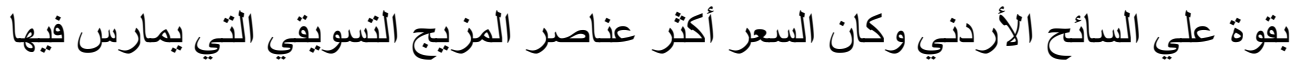

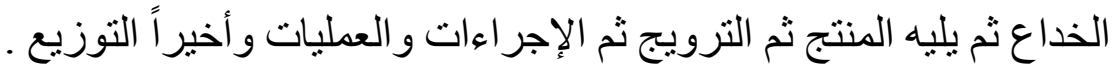

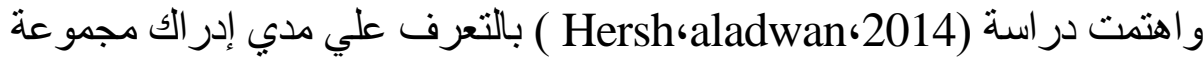
من السياح للخداع التسويقي الذي يمارس من قبل شركات السفر و السياحة العاملة في

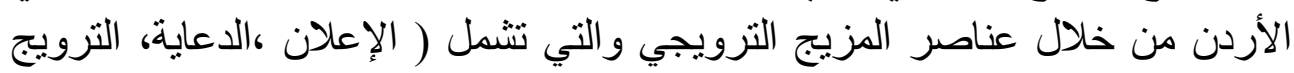

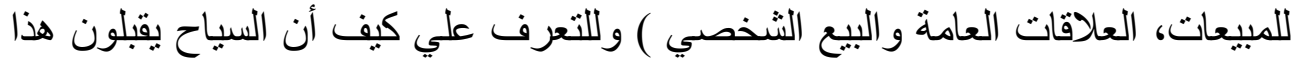

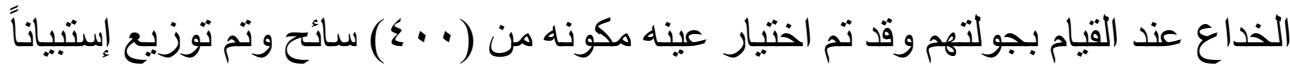

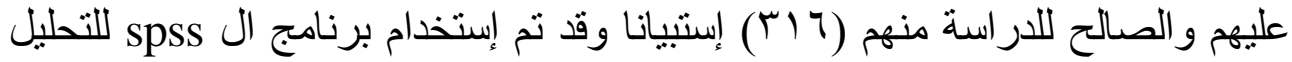

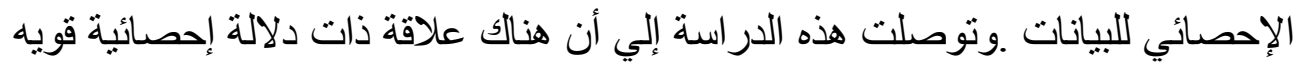
بين عناصر المزيج الترويجي و الخداع التسويقي للسياح. واستهدفت دراسة (Wilkins et al.,2015) قياس أثر الخداع في التعبئة (تكبير حجم العبوة دون المحتوي ،تخفيض المحتوي داخل نفس العبوة )علي النوايا

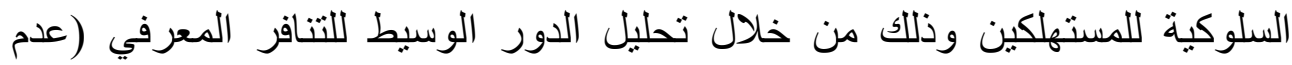

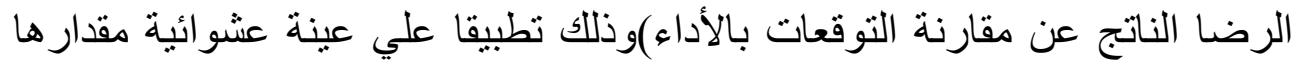

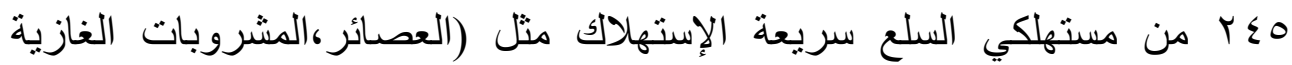
،الثيكو لاتة )وتم تجميع البيانات من خلال عرض مجمو عه من الصور تمثل أنثالا 


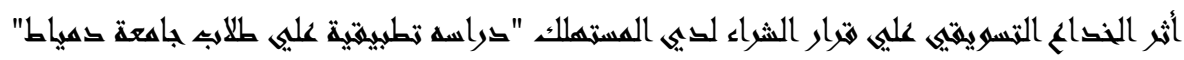

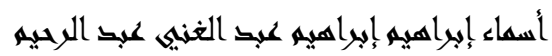

مختلفة لتعبئة أحد منتجات الثيكولاتة وطلب من المستقصي منهم الإجابة علي

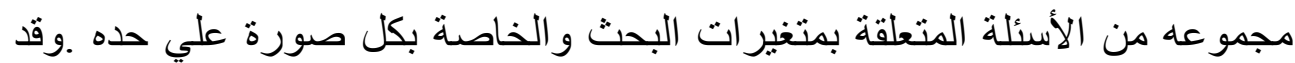
توصلت هذه الدراسة الي وجود علاقة إيجابية معنوية بين توقعات العمبل بالنسبة الإنة

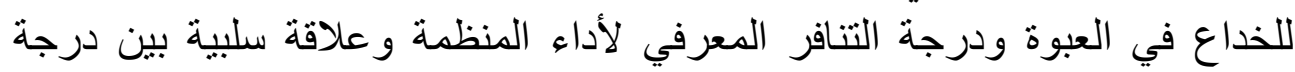

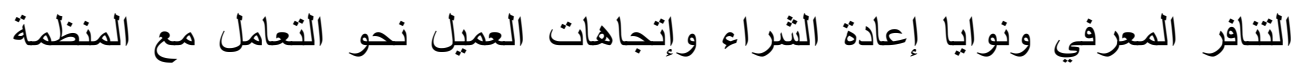

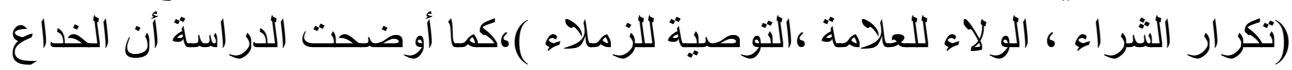

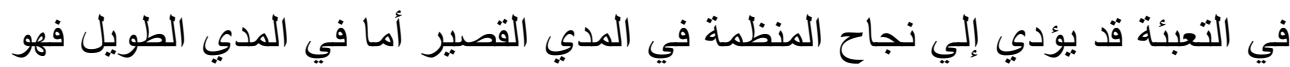

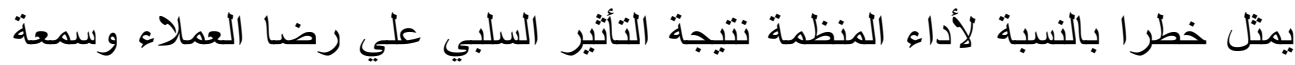
المنظمة ودرجة الو لاء.

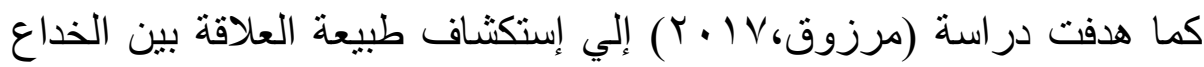
التسويقي وولاء العميل بالتطبيق علي عملاء شركات الإتصالات بوسط الدلتا

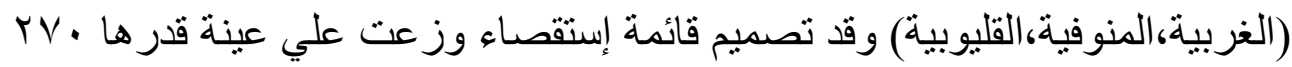
عميل من عملاء شركات الاتصالات العاملة بالسوق المصري وفئهة (فودافون، أورانج،

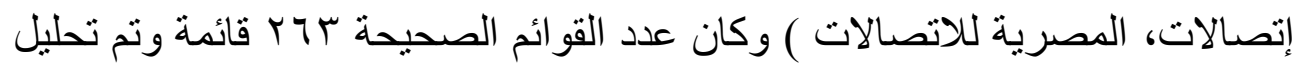

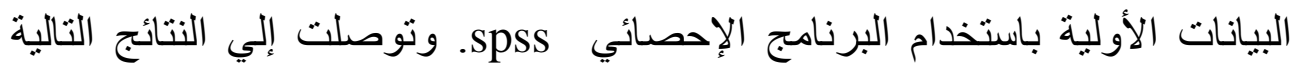

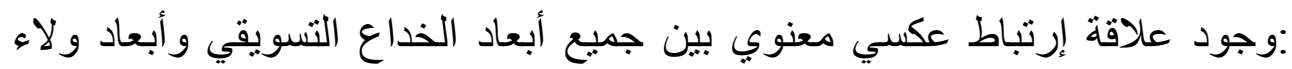

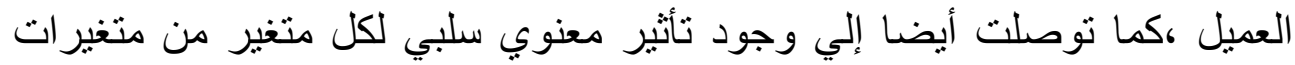

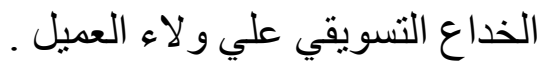

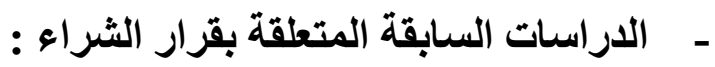

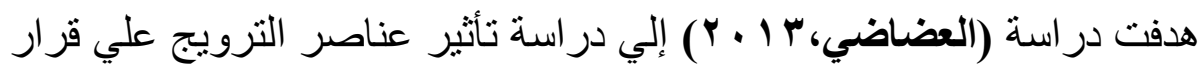
الشراء للمستهلك وقد تم استخدام عينه ملائمة تم أخذها من منطقة عسير بالئر عالمملكة

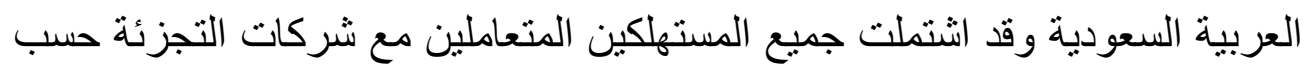

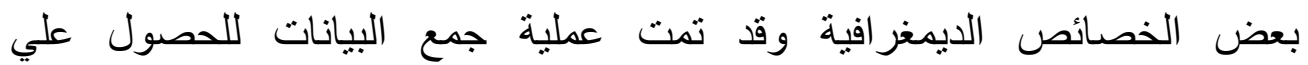

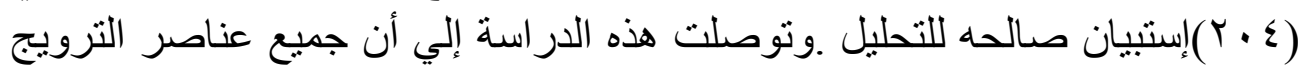

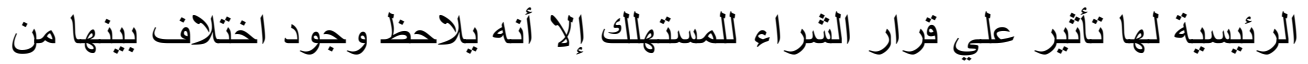




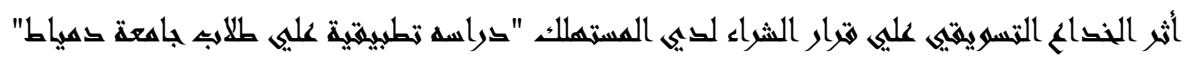

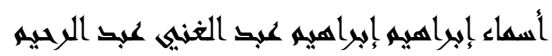

حيث درجة المو افقة ،كما بينت نتائج الدراسة أن عنصر "تتشيط المبيعات "يمثل أكثر

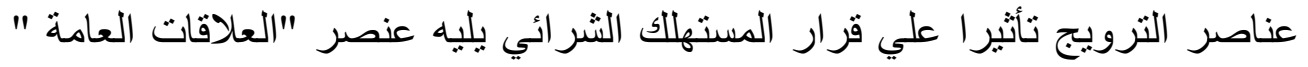

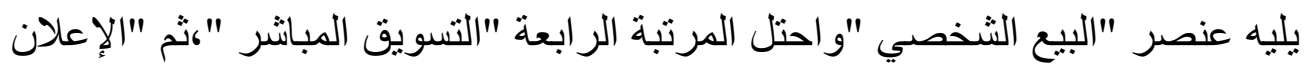

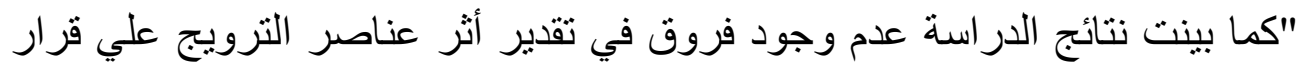

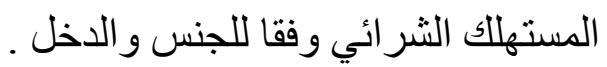

هدفت دراسة (Wijaya,Silalahi,2015) إلي معرفة تأثير متغيرات المزيج

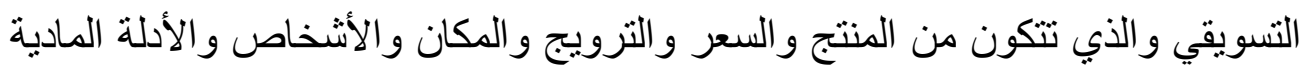

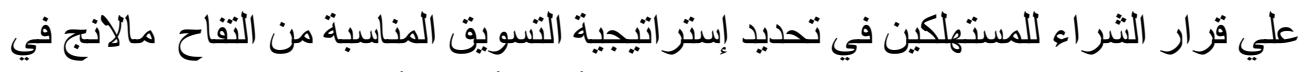

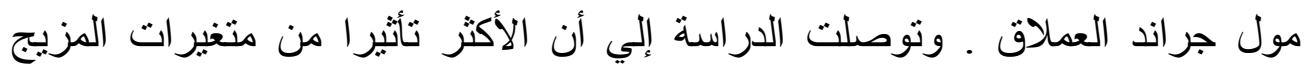

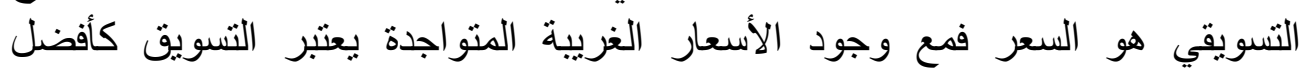

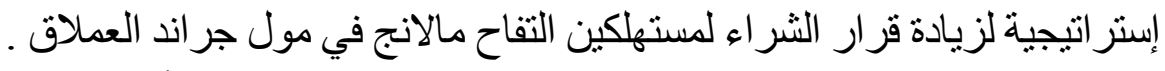
هدفت دراسة(Hastuti Moh,etal.,2018) إلي تحديد تأثير صورة فورة العلامة التجارية والسعر علي قرار الثراء تطبيقا علي الهو اتف الذكية oppo في مدينة كينداري حيث تم التطبيق علي عينة مكونه من • 7 مستجيب وقد تم استخدام تحليل الانحدار الخطي

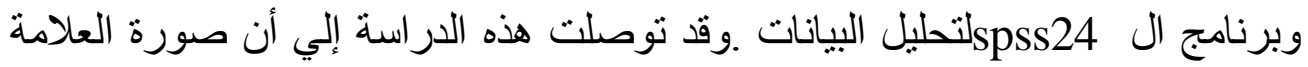

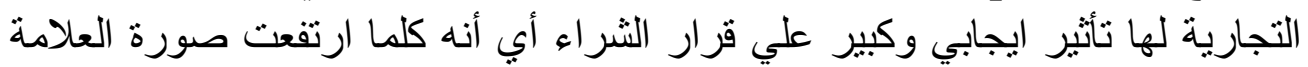

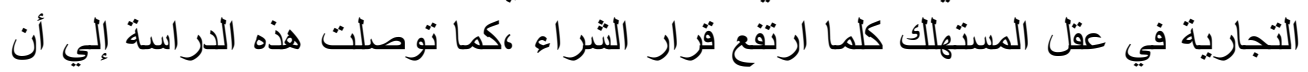
تصور السعر له تأثير إيجابي وكبير علي قرار شراء الهواتف الذكية oppo حيث يصبح

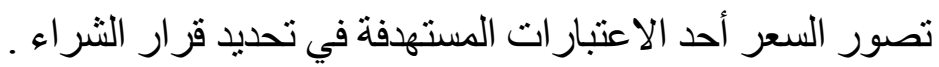

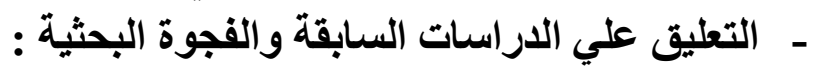

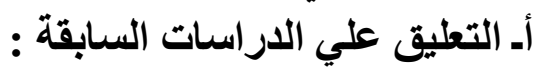
يتضح من خلال دراسة وتحليل الدراسات السابقة أن بعض الدابله الدراسات تناولت مايلي

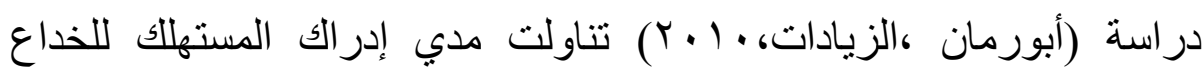

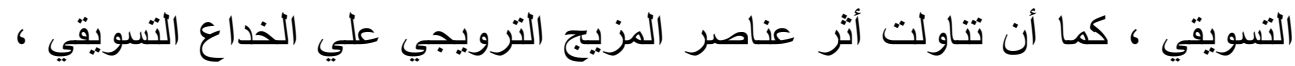




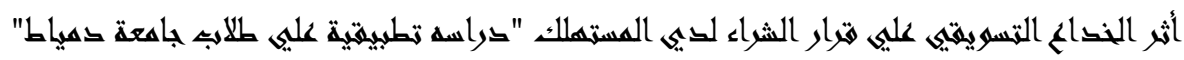

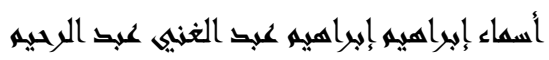

(Hersh,aladwan,2014)

بينما تناولت در اسة (wilkins,etal.,2015) أثر الخداع في التعبئه علي رضا

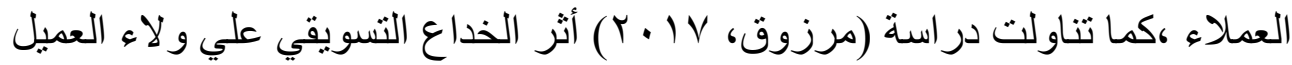

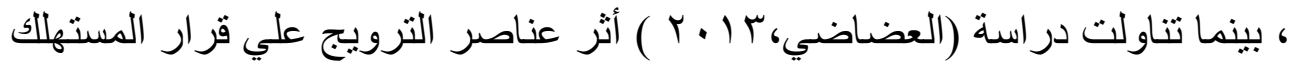
الثرائي ،كما نتاولت دراسة (wijaya,silalahi,2015) أثر التسويق علي قرار

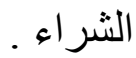

سوف نتناول هذه الدراسة الخداع التسويقي من خلال مجموعه من الأبعاد

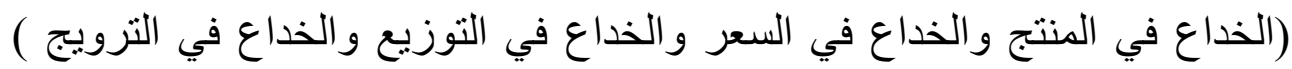

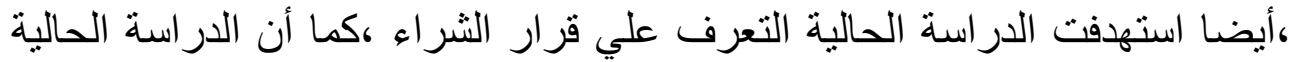

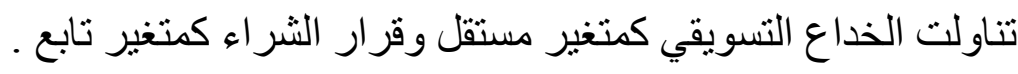

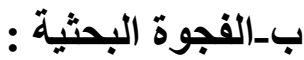

من خلال إستعراض وتحليل الدراسات السابقة اتضح أن هناك فجوة بحثية

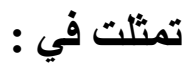

ندرة الدراسات العربية التي تناولت الخداع التسويقي مقارنة بالدر اسات الأجنبية علي حد علم الباحثة ،بالإضافة إلي أن هنالك ندرة في الدراسات العربية التي تناولت التان

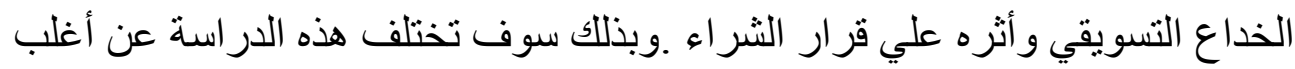

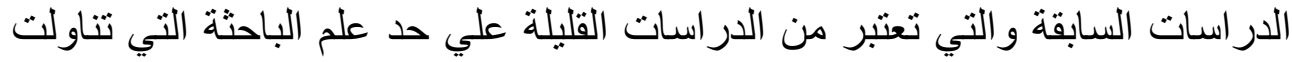

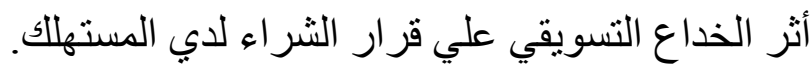
ثانيا :الاراسة الإستطلاعية: أهداف الدراسة الإستطلاعية :

إستكمالاً لما أسفرت عنه الدراسات السابقة ومحاولة الباحثة وضع إطار لأثر الخداع التسويقي علي قرار الثراء لدي المستهلك لدي طلاب جامعة دمياط ولتحديد

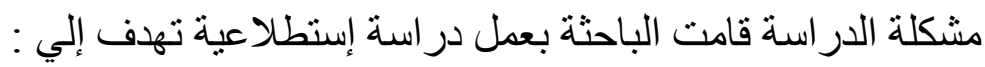

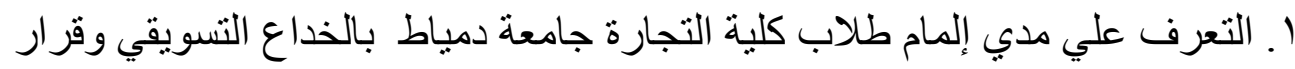

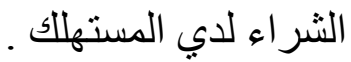




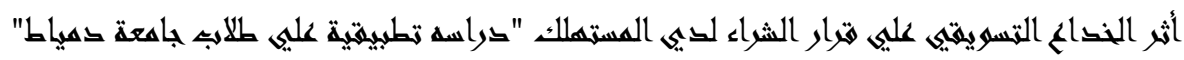

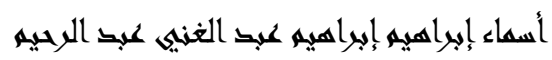

r. معرفة مدي إلمام طلاب كلية التجارة جامعة دمياط بعناصر الخداع التسويقي وقرار الثراء. معنه r. معرفة أكثر العناصر جذبا للانتباه للخداع التسويقي وأي من هذه العناصر يؤثر بشكل كبير علي قرار الثر اء لدي طلاب الكلية .

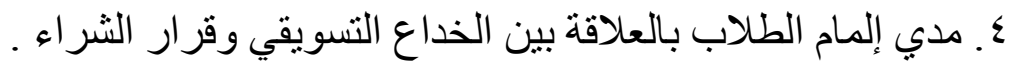

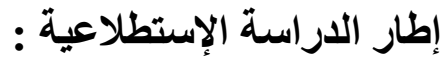

قامت الباحثة بإجر اء مقابلات متعمقة مع طلاب كلية التجارة التبارة جامعة دمياط

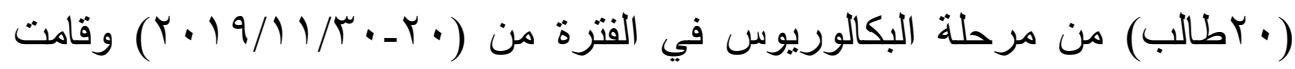
الباحثة بطرح عدد من الأسئلة التي تم إعدادها إعتمادا علي الدي الدراسات التئ السابقة

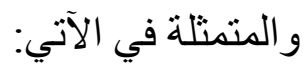

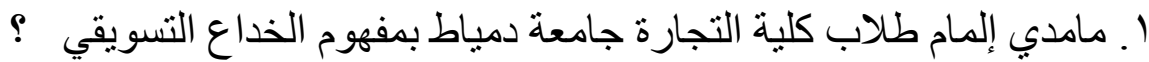

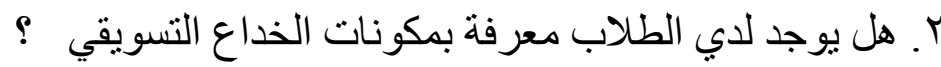

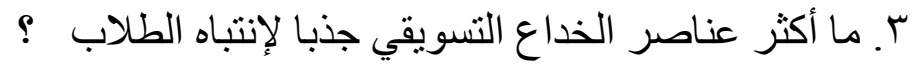

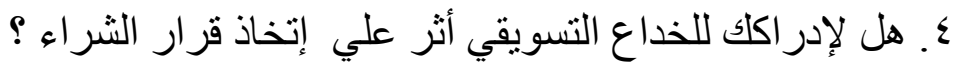

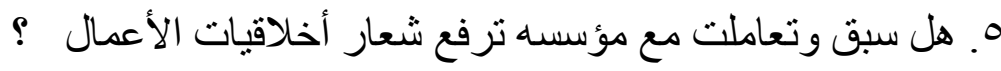

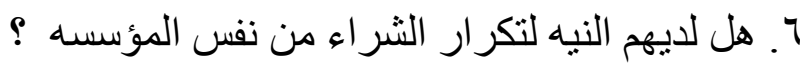

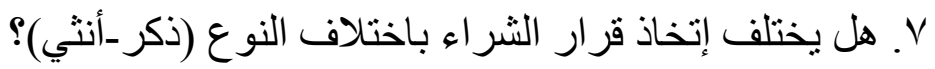

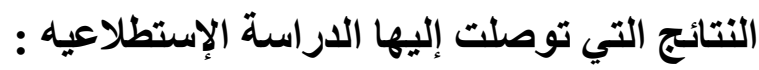
وقد توصلت الباحثة إلي العديل من النتائج التي يمكن الإثارة إليها اليها في ما يلي :

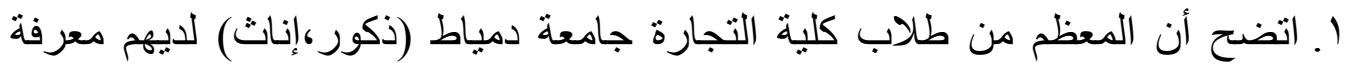

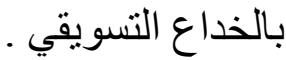
r. اتضح أن الأغلبية من طلاب كلية التجارة جامعة دمياط(ذكور، إناث) تعرضوا للخداع

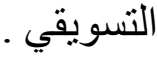
r. اتضح أن بعض طلاب كلية التجارة جامعه دمياط (ذكور،إناث) ليس لديهم معرفه بالخداع التسويقي في التوزيع و الترويج .

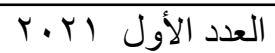




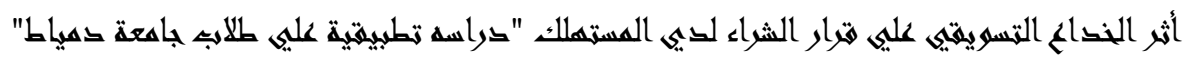

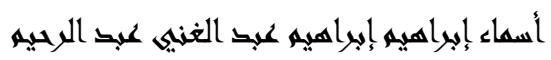

ع. اتضح أن الأغلبية من طلاب كلية التجارة جامعة دمياط (ذكور،إناث)لديهم معرفه

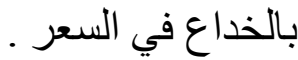
○. اتضح أن الأغلبية من طلاب كلية التجارة جامعة دمياط (ذكور إناث) إدر اكهم للخداع

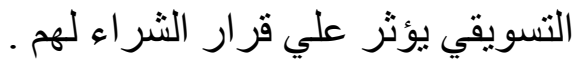
7 ا اتضح أن الأغلبية من طلاب كلية التجارة جامعة دمياط (ذكور، إناث) لم يتم تعاملهم

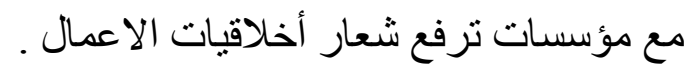
V. اتضح أن الأغلبية من طلاب كلية التجارة جامعة دمياط (ذكور، إناث) لم يكرروا

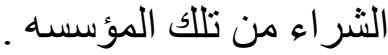

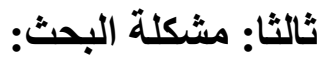

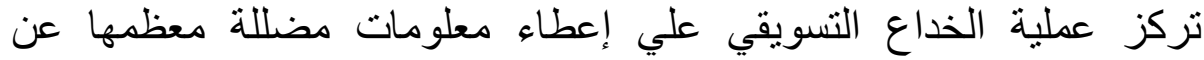

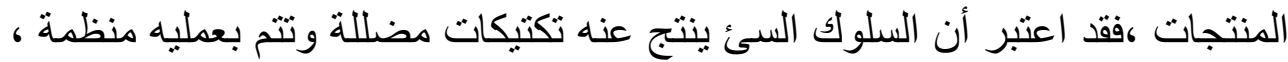
ويمكن بكل بساطة أن يدرك المستهلك الخداع التسويقي حينما يعتقد أن البائع قد فئه

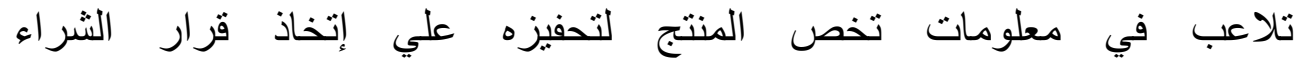
(Riquelme,Roman,2014)

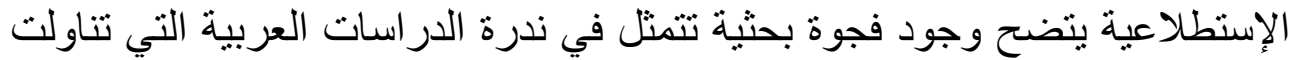

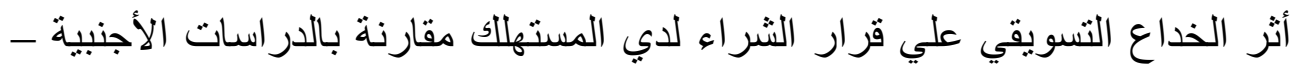

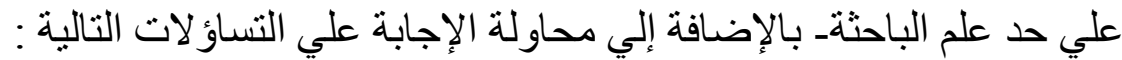

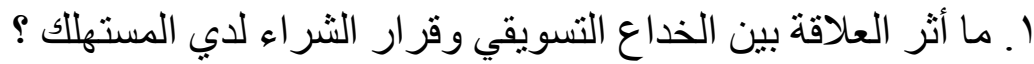

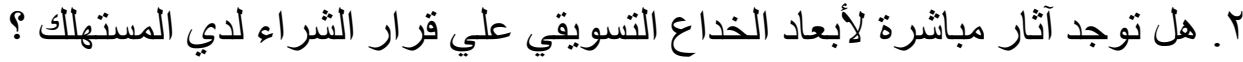

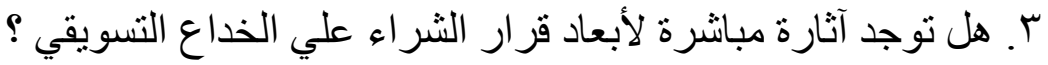

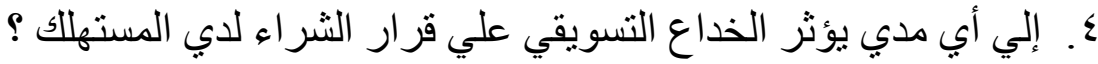

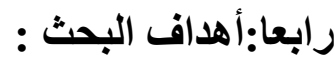
إنطلاقا من عرض الباحثة لمشكلة وتساؤلات الدراسة فإنه يمكن تناول أهداف هذه

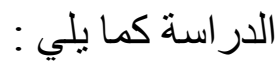
ا .التعرف علي نوع وطبيعة العلاقة بين الخداع التسويقي وقرار الثر اء للمستهلك . 


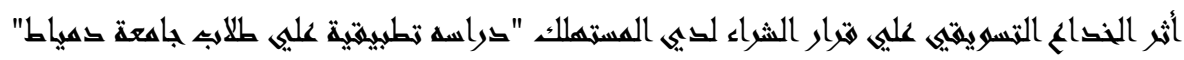

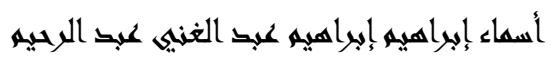

r.قياس التأثثر المباشر لأبعاد الخداع التسويقي علي أبعاد قرار الثراء.

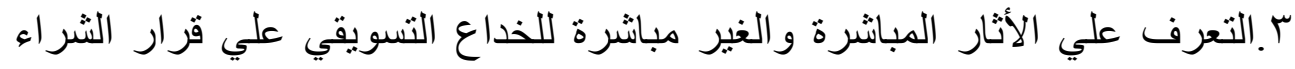
للمستهـ

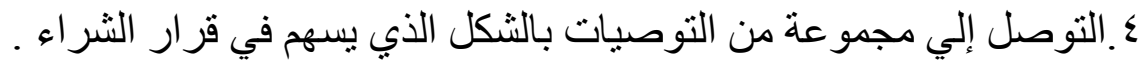
خامسا: فروض الاراسة : في ضوء مشنكة الدراسة وأهدافها ،تم صياغة مجموعة الرفة الفروض البحثية التي سيتم

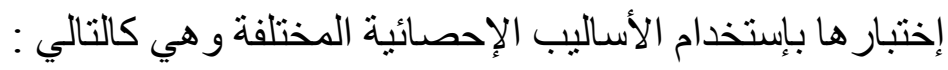

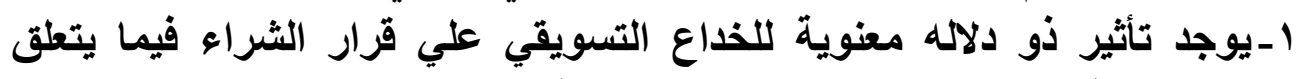

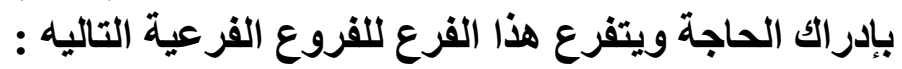

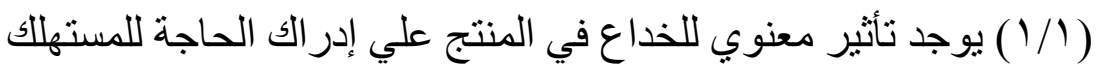
يو جد/T)

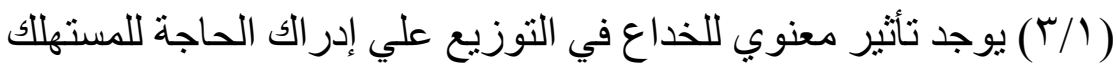

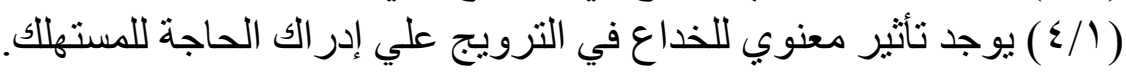

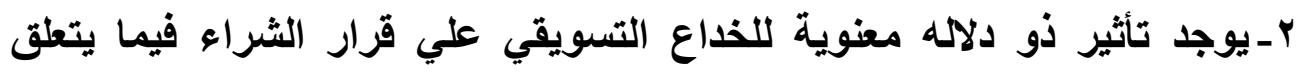

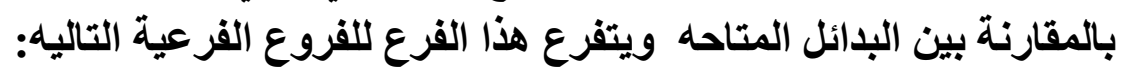

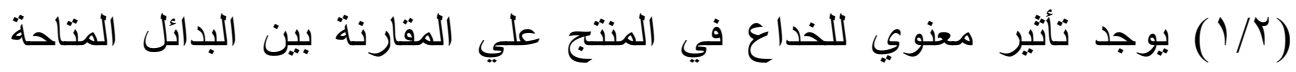
للمستهـ

(Y/Y) للمسته/ (T/Y) يوجد تأثثر معنوي للخداع في التوزيع علي المقارنة بين البدائل المتاحة للمسته|لك . (飞/ץ) يوجد تأثير معنوي للخداع في الترويج علي المقارنة بين البدائل المتاحة للمستهلك . بـ - يوجد تأثير ذو دلاله معنوية للخداع التسويقي علي قرار الشراء فيما يتعلق بتقييم البدائل المتاحة ويتفرع هذا الفرع للفروع الفرعية التاليه:

العدد الأول I.r. 


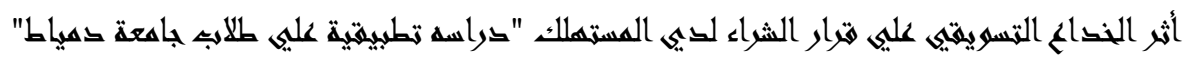

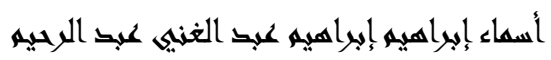

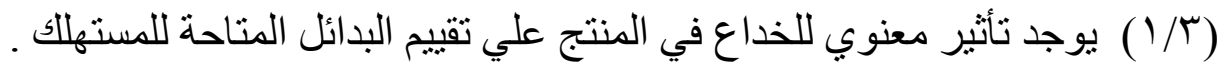
(Y/T)

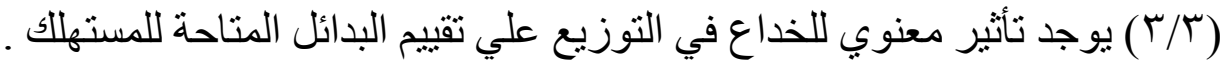

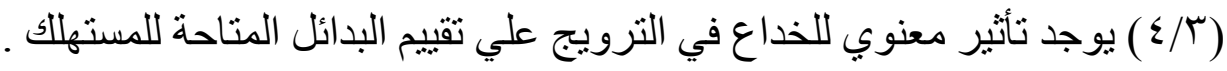

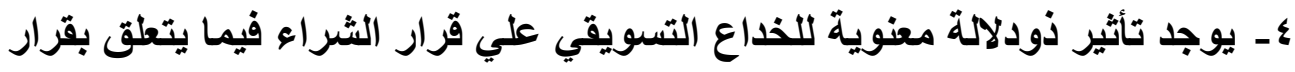
الشراء الفعلي ويتفرع هذا الفرع للفروع الفرعية التاليه:

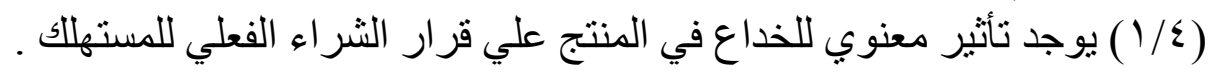

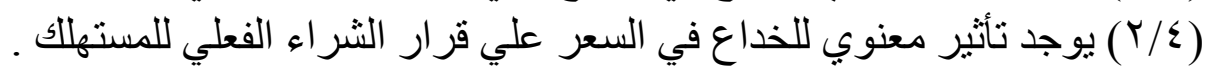

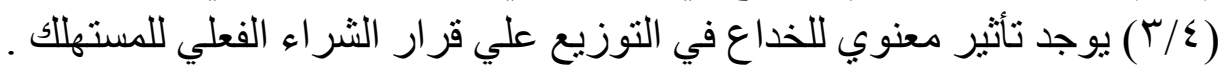

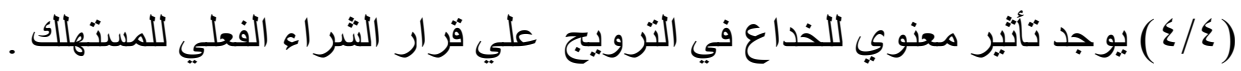

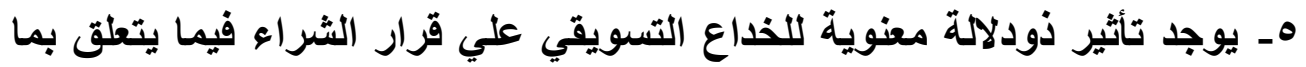
بعد الثراء ويتفرع هذا الفرع للفروع الفرعية التاليه:

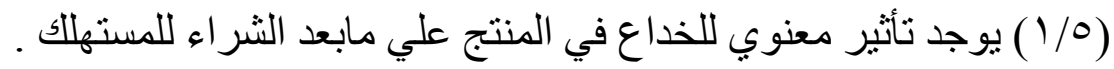

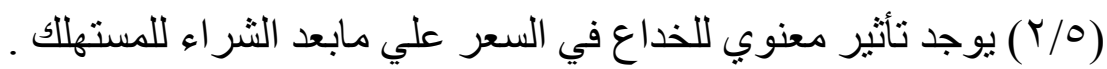

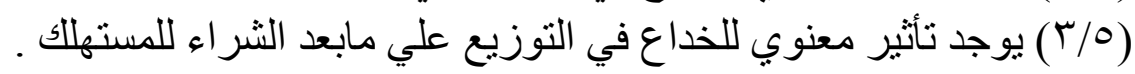

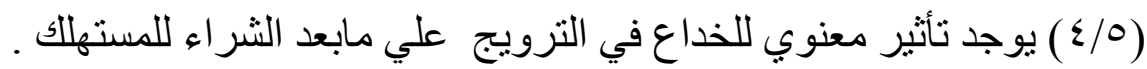

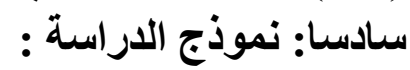

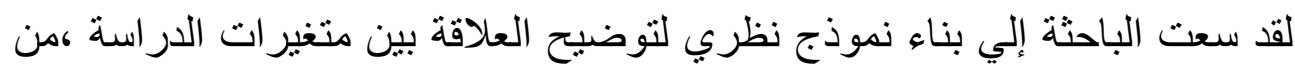

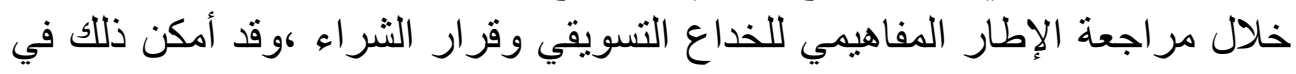
وضع تصور مبدئي للنموذج كما يتضح في الثكل رقم (1) 


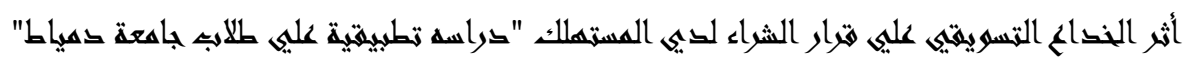

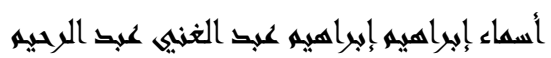

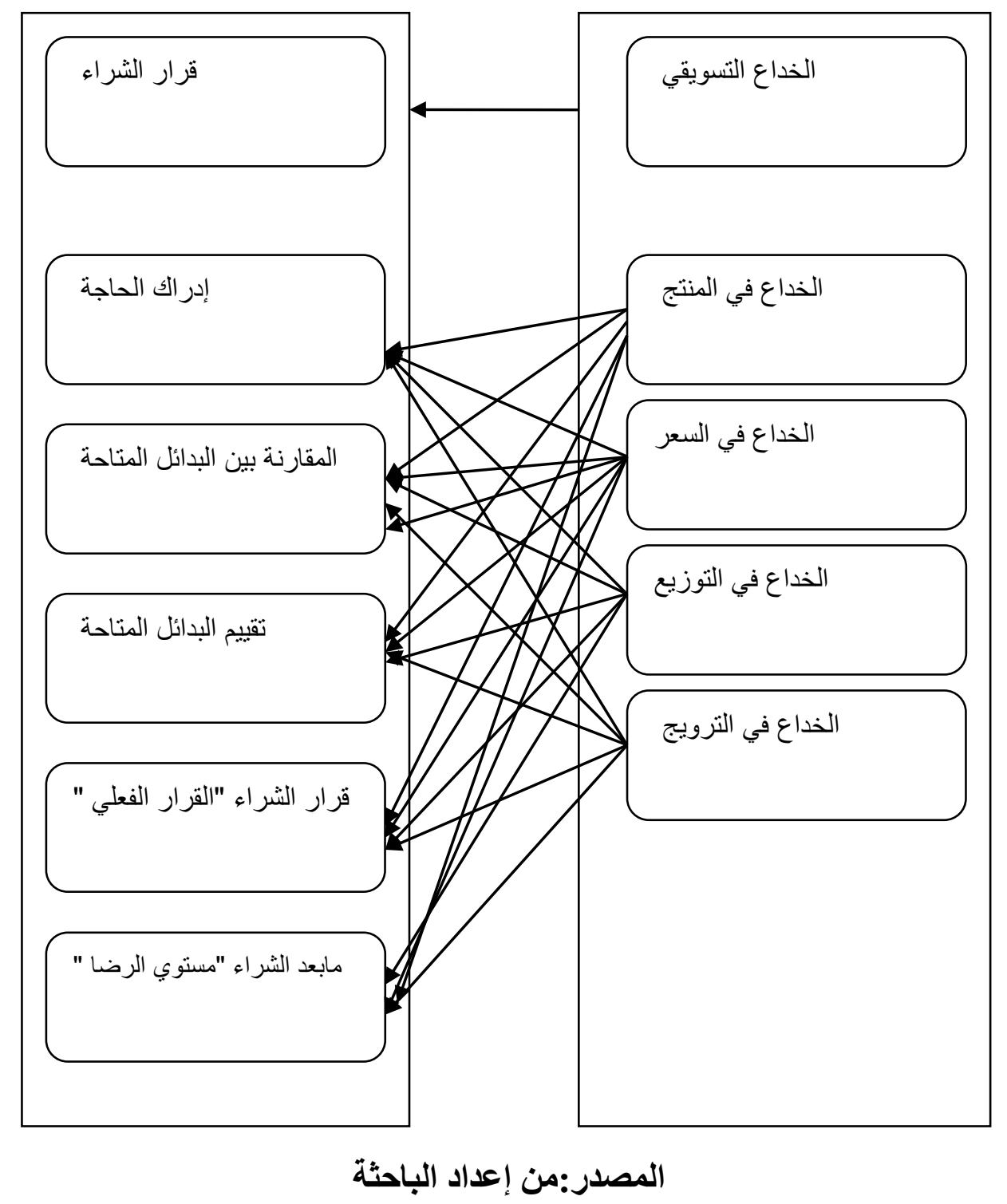

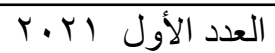




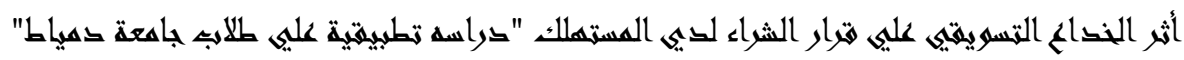

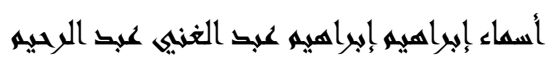

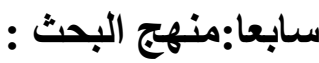

أ_نوع ومصادر البيانات :

سوف يعتمد البحث علي نو عين من البيانات وذللك علي النحو التالي :

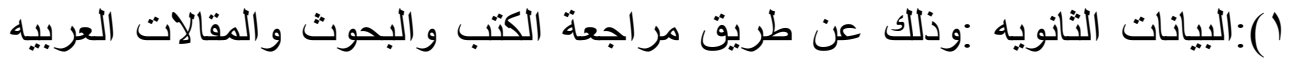

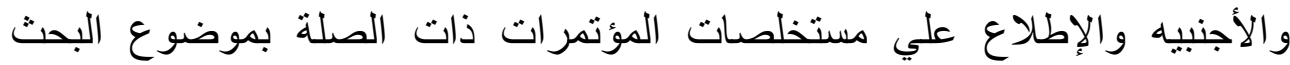

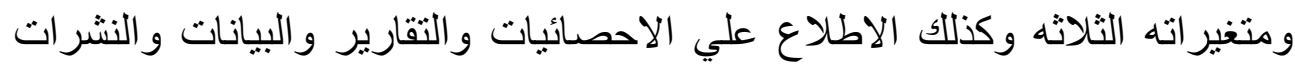

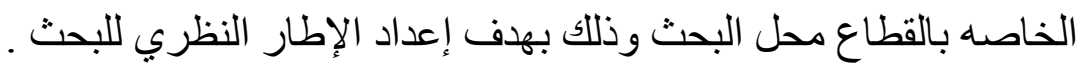
r):البيانات الاوليه :وذللك عن طريق جمع البيانات الغير منشورة بإستخدام المقابلات

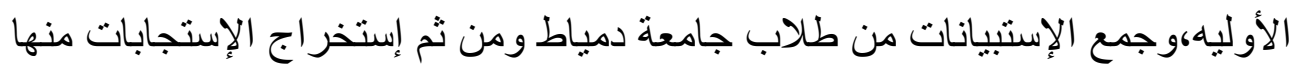

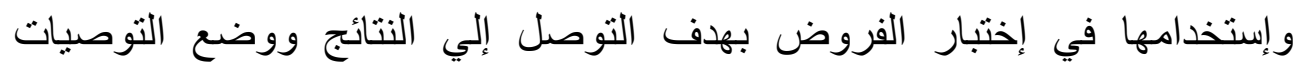
المناسبه .

ثامنا:مجتمع الاراسة : باسه يتمثل مجتمع الدر اسة في طلاب جامعة دمياط دون غير هم من طلاب الدار اسات العليا

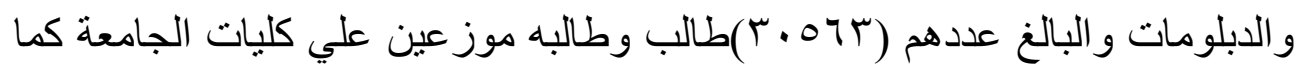

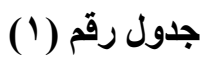

\begin{tabular}{|c|c|c|c|}
\hline النسبة إلي الإجمالي & عدد الطلاب & الكلية & م \\
\hline$\% Y$ & $70 \leqslant 1$ & كلية التربية & 1 \\
\hline$\% r$ & 974 & كلية العلوم & $r$ \\
\hline$\% \vee$ & $r \cdot v q$ & كلية التربية النوعية & $r$ \\
\hline$\% r r$ & 7700 & كلية التجارة & $\varepsilon$ \\
\hline$\% 19$ & 0179 & كلية الأداب & 0 \\
\hline$\% r$ & $1 \cdot \lambda r$ & كلية الفنون التطبيقية & 7 \\
\hline$\% 0^{\circ}$ & 1049 & كلية الزراعة & $V$ \\
\hline$\% r$ & 997 & كلية التربية الرياضية & $\Lambda$ \\
\hline$\% \varepsilon$ & $111 \varepsilon$ & كلية الهندسة & 9 \\
\hline
\end{tabular}

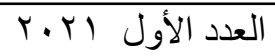




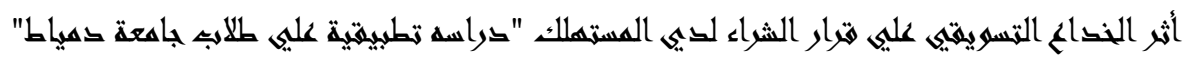

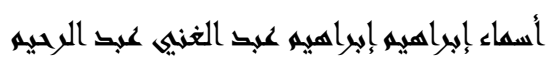

\begin{tabular}{|c|c|c|c|}
\hline$\%$ & $\wedge \leq \varepsilon$ & كلية الآثار & 1. \\
\hline$\% V$ & $r \cdot \Sigma l$ & كلية الحقوق & 11 \\
\hline$\% 1$ & rra & كلية الحاسبات و المعلومات & ir \\
\hline$\% r$ & $0 . \varepsilon$ & كلية التمريض & $1 \pi$ \\
\hline
\end{tabular}

المصدر:إعداد الباحثة

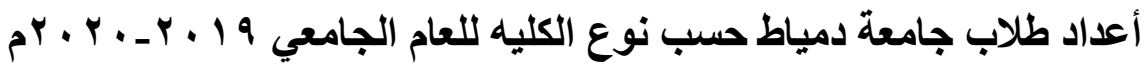

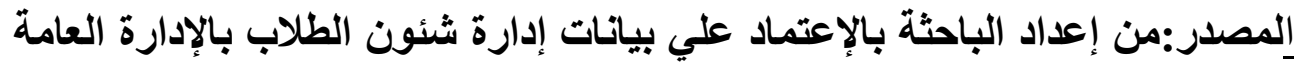
لجامعة دمياط. تاسعا: عينة الار اسمة دمباطة

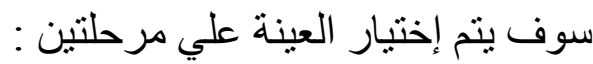

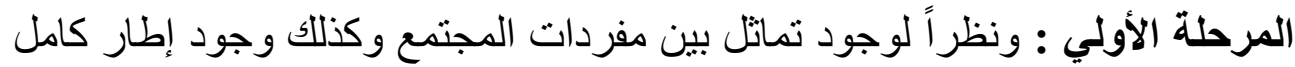

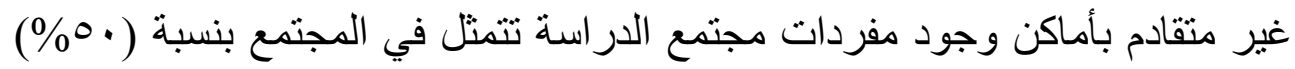

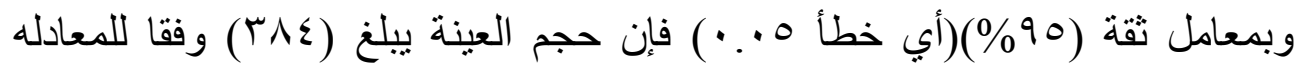
التاليه:

$$
\mathrm{n}=\mathrm{Z} 2 \mathrm{~L}(1-\mathrm{L}) / \mathrm{D} 2
$$
حيث أن :

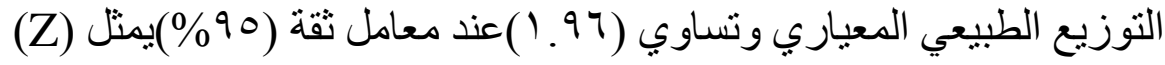

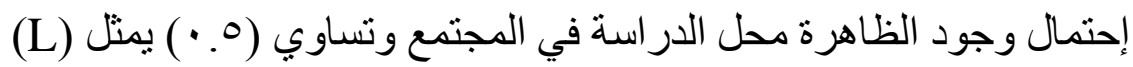

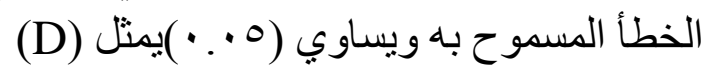
وبعد تحديد حجم العينة المبدأي يتم عمل تصحيح للعينه بإعتبار أن حجم العينة

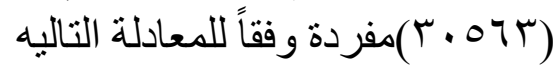

$$
\mathrm{n} *=\mathrm{n} /((\mathrm{n} / \mathrm{N})+1)
$$

حيث أن N يثير إلي حجم المجتمع $n *=384 /((384 / 30563)+1)=379$ 


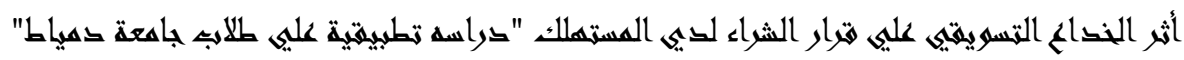

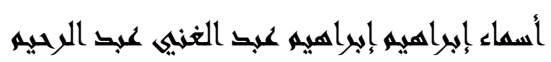

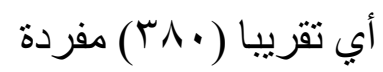

المرحلة الثانية : إختيار عينة عشودائية حصصية بناءا علي نسبة الطلاب بكل كلية

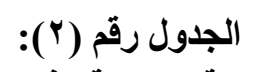

\begin{tabular}{|c|c|c|c|c|}
\hline حجم العينة المناسب & النسبة إلي الإجمالي & عدد الطلاب & الكلية & p \\
\hline$\wedge$ & $\%$ Y & $70 \leqslant \Lambda$ & كلية التربية & 1 \\
\hline 11 & $\% r$ & 977 & كلية العلوم & $r$ \\
\hline TV & $\% \mathrm{~V}$ & $r \cdot v q$ & كلية التربية النوعية & $r$ \\
\hline$\wedge \varepsilon$ & $\% Y r$ & 7700 & كلية التجارة & $\varepsilon$ \\
\hline$V Y$ & $\% 19$ & $0 \wedge 79$ & كلية الأداب & 0 \\
\hline 11 & $\% r$ & $1 \cdot \lambda r$ & كلية الفنون التطبيقية & 7 \\
\hline 19 & $\% 0^{\circ}$ & 1047 & كلية الزراعة & V \\
\hline 11 & $\% r$ & $99 V$ & كلية التربية الرياضية & $\wedge$ \\
\hline 10 & $\% \varepsilon$ & $111 \varepsilon$ & كلية الهندسة & 9 \\
\hline 11 & $\% r$ & $\lambda \varepsilon \varepsilon$ & كلية الآثار & 1 . \\
\hline$T V$ & $\% \vee$ & $Y \cdot \Sigma l$ & كلية الحقوق & 11 \\
\hline$\varepsilon$ & $\% 1$ & ris & كلية الحاسبات و المعلومات & Tr \\
\hline$\Lambda$ & $\% Y$ & $0 . \varepsilon$ & كلية التمريض & $\pi$ \\
\hline rᄉ. & & ـالي & & \\
\hline
\end{tabular}

تقسيم عينة الاراسة وفقا لكل كلية

\section{المصدر:إعداد الباحثة}

عاشر ا: أسلوب تحليل البيانات :

سوف يقوم الباحث بإستخدام البرنامج الإحصائي(Spss version 25) ومن ثن ثن

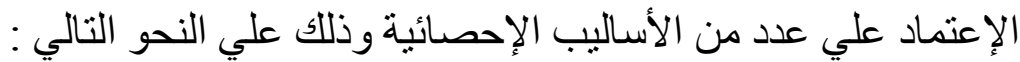

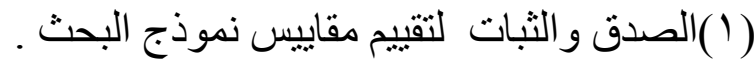

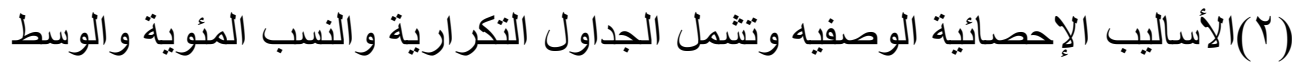

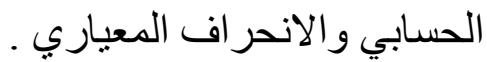
(ץ)(أسلوب "معامل ألفا كرونباك" وذللك للتأكد من درجة الثبات في المقاييس الخاصه 


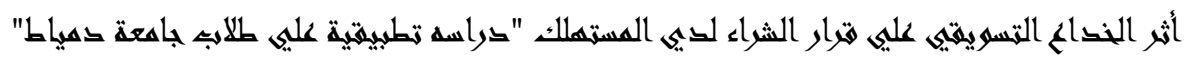

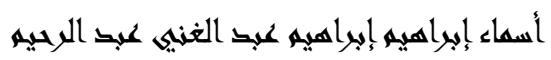

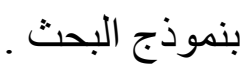

(ع)(إختبار "ت" (t-test)وذلك للتحقق من معنوية الفروق بين مفردات العينه .

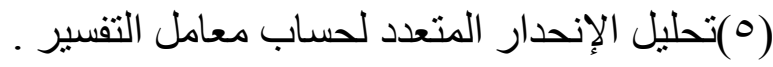
(7)معامل إرتباط بيرسون بهدف إختبار الصدق التمايزي لمقاييس النموذج .

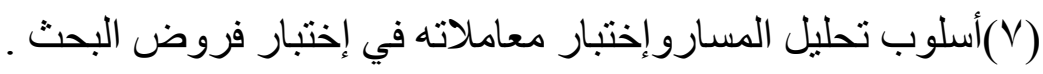

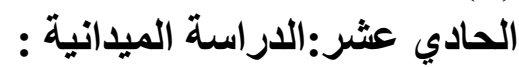

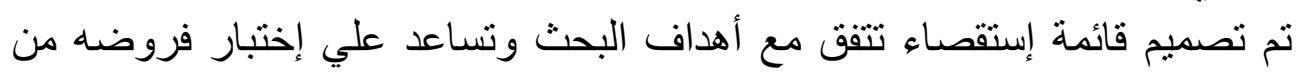
خلال قياس متغير اته ،وقد اعتمدت الباحثه في تصميم هذه القائمة علي الفي اربعه مقاييس جاهزة ومستخدمة في البحوث السابقة وذللك علي النحو التالي : *سوف يتم قياس الخداع التسويقي الذي يمثل المتغير المستقل للبحث بإستخدام

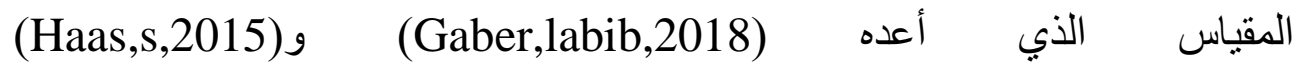

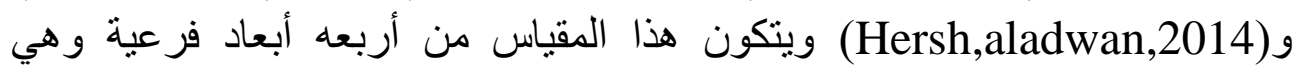
(الخداع في المنتج،الخداع في السعر ،الخداع في التوزيع،الخداع في الترويج )ويتم

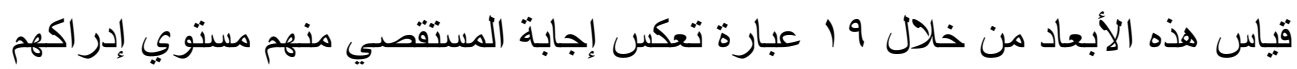

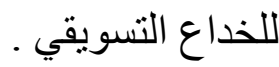
* سوف يتم قياس قرار الثراء الذي يمثل المتغير التابع للبحث باستخدام المقياس الذي

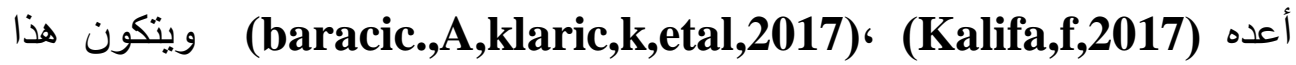
المقياس من خمسة أبعاد فرعيه وهي (إدرالك الحاجه،البحث عن المعلومات،ثقيثيم البدائل ،قرار الثراء ،مابعد الثراء ) ويتم قياس هذه الأبعاد من خلاد

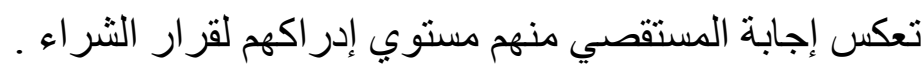
-تقييم نماذج القياس: سوف يتم تقييم نماذج القياس المكونه للنموذج البنائي للبحث بهدف التأكد من أن هذه

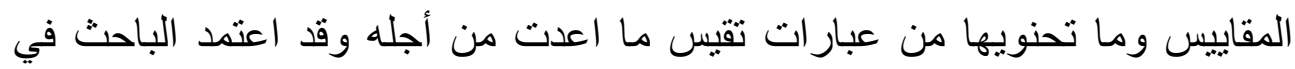
اجر اء هذا التقييم علي الأتي : 


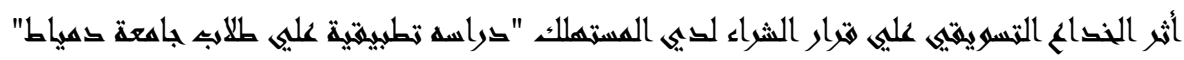

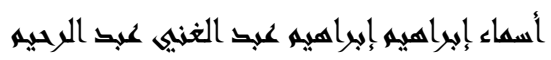

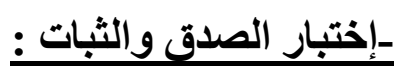

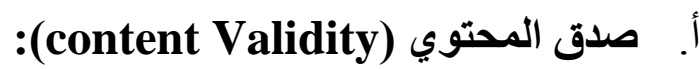

ولقياس صدق المحتوي قامت الباحثة بعرض قائمة الاستبيان في صورنها الأولية المانية

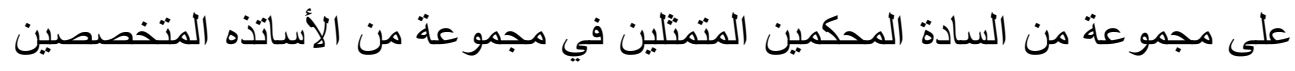

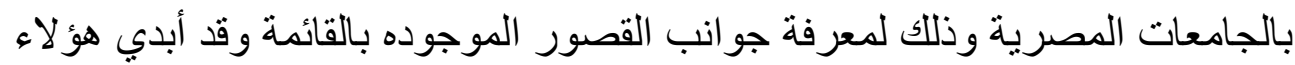

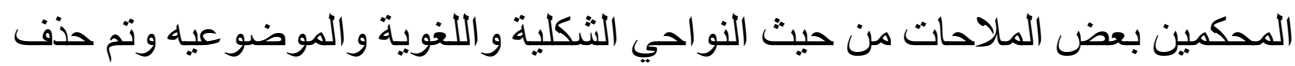
بعض العبار ات و إعادة صياغة البعض الأخر لتكون ذات التهات دلاله أكثر وضوحا.

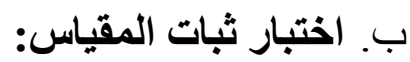
نم اختبار ثبات المقياس المستخدم عن طريق استخدام معامل ألفا كرونباخ

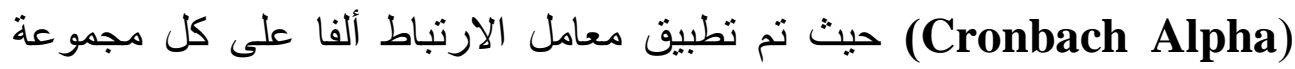

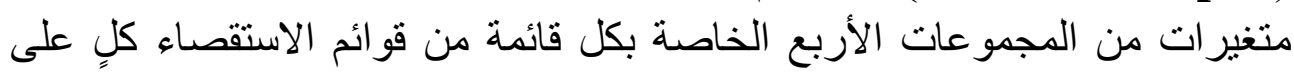

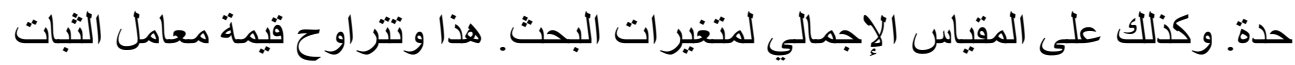

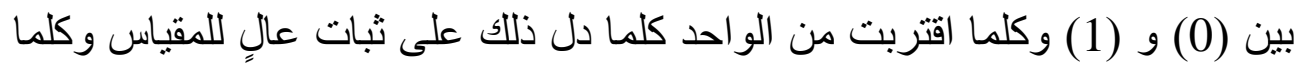

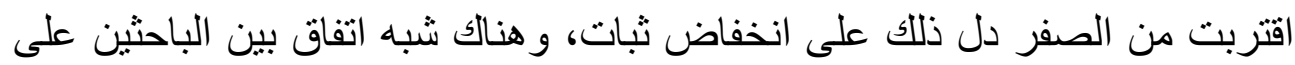

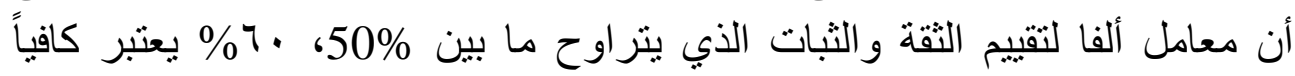

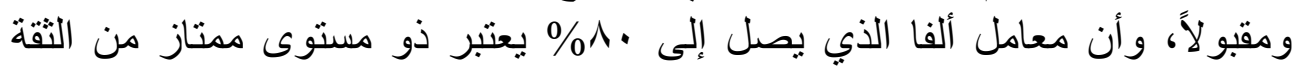
و الثبات

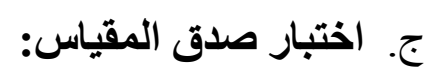
تم اختبار صدق المقياس صني عن طريق حساب معامل الصدق لكل قائمة من قوائم الاستقصاء، وذللك باستخدام المعادلة التالية:

معامل الصدق = معامل الثبات

وفيما يلي نتائج معامل ألفا للثبات، وكذلك نتائج معامل الصدق المتعلقة باستجابات عينة البحث على متغير من متغير ات البحث: 


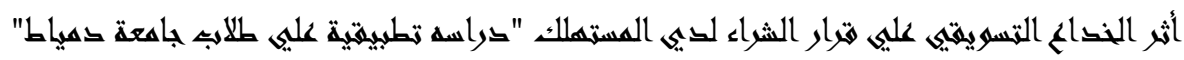

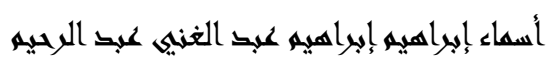

ا ـ. اختبار الصدق والثبات الخاص بمقياس الخداع التسويقي: يوضح الجدول رقم (r) نتائج معاملات الثبات والصدق الثباس الثنعلقة بمقياس الخداع

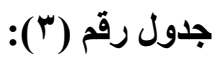

التسويقي.

معاملات الثبات المتعلقة بأبعاد الخداع التسويقي (بطريقة ألفا كرونباخ)

\begin{tabular}{|c|c|c|c|c|c|}
\hline معامل الصدق & قيمة معامل ألفا للثبات & علدار & الأسئلة & المتغيرات & القسم \\
\hline 0.879 & 0.774 & $r$ & $r: 1$ & الخذاع في المنتج & الأول \\
\hline 0.916 & 0.840 & 7 & $9: \varepsilon$ & الخداع في الستر & الثاني \\
\hline 0.895 & 0.802 & 0 & $1 \leqslant: 1$. & الخداع في التوزيع & الثالث \\
\hline 0.856 & 0.734 & 0 & $19: 10$ & الخداع في الترويج & الرابع \\
\hline 0.941 & 0.886 & 19 & $19: 1$ & الخداع التسويقي & الإجمالي \\
\hline
\end{tabular}
المصدر: من إعداد الباحث وفقاً لنتائج التحليل الإحصائي.

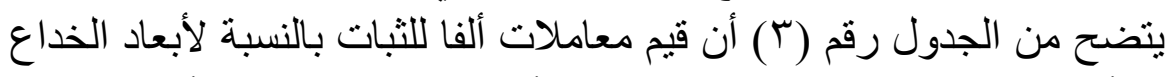

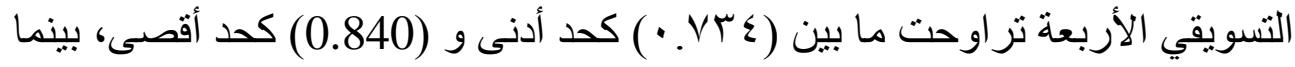

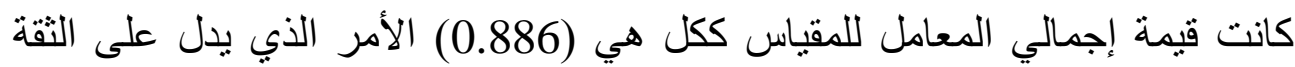
و الثبات في هذه الاستجابات. كما تراوحت قيم معاملات الصدق الذاتي لأبعاد الخداع

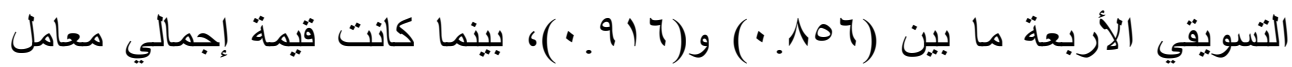

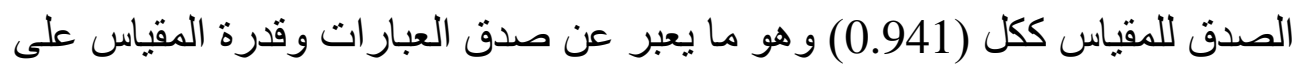
قياس ما وضع لقياسـ. r. اختبار الصدق والثبات الخاص بمقياس قرار الشراء التسويقي: يوضح الجدول رقم (ع) نتائج معاملات الثبات و الصدق المتعلقة بمقياس قرار ار الثراء الثراء. 


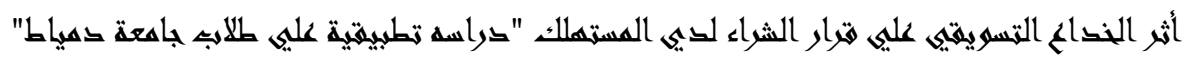

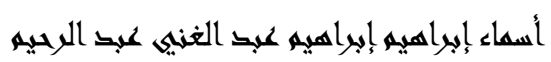

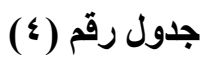

معاملات الثبات المتعلقة بأبعاد قرار الشراء (بطريقة ألفا كرونباخ)

\begin{tabular}{|c|c|c|c|c|c|}
\hline الصدق & للثباتة معامل ألفا & ع علدارت & الأسئلة & المتغيرات & القسم \\
\hline .911 & $\cdot \Delta \Gamma$. & $r$ & TYYY. & مرحلة إدراك الحاجة & الأول \\
\hline .909 & .94. & $r$ & rO:Yr & البدائلة & ني \\
\hline. . AOr &.$V Y Y$ & $r$ & YA:YT & مرحلة تقييم البدائل & الثالث \\
\hline $.9 \leqslant \leqslant$ & $\cdot . \wedge 94$ & $r$ & r::rq & مرحلة اتخاذ قرار الثراء & الرابع \\
\hline$\cdot . \wedge V Y$ & $\cdot$ VIT & $\mu$ & $T \leqslant: r r$ & مرحلة ما بعد الثراء & الخامس \\
\hline .904 & .9 .9 & 10 & $r \varepsilon:{ }^{\top}$ & قرار الثراء & الاجمالي \\
\hline
\end{tabular}

المصدر: من إعداد الباحث وفقاً لنتائج التحليل الإحصائي.

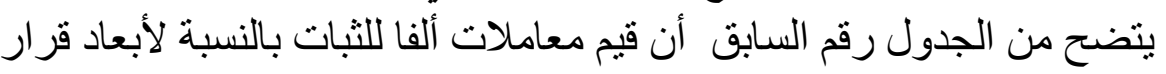

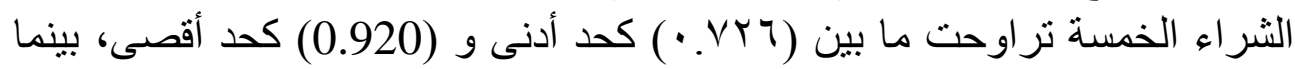

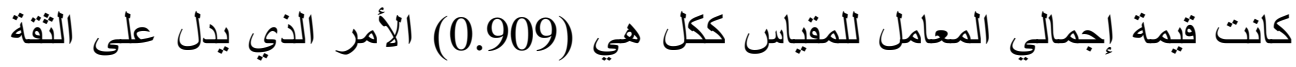

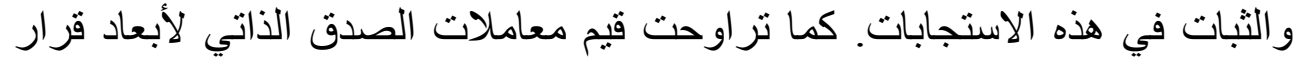

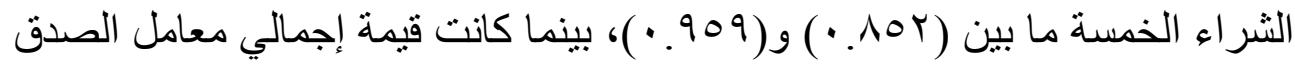
للمقياس ككل (0.953) وهو ما يعبر عن صدق العبار ات وقدرة المقياس على قياس ما وضع لقياسـ. التحليل الوصفي وفئي (1/ ( ) وصف عينة الدراسة وفقاً للبيانات الايموغرافية

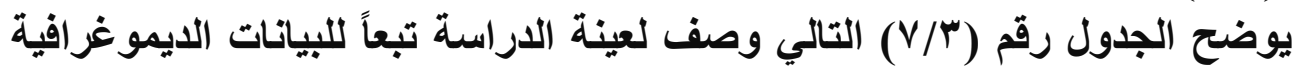

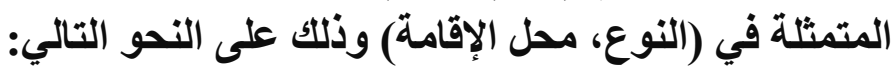




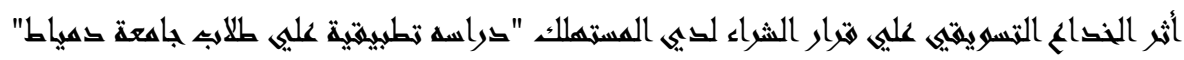

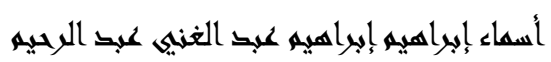

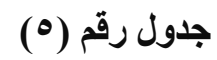

وصف عينة الدراسة وفقاً للبيانات الايموغرافية

\begin{tabular}{|c|c|c|c|}
\hline النسبة \% & العدد & البيان & المتغير \\
\hline$\% 47.9$ & 196 & أنثى & \multirow{3}{*}{ النوع } \\
\hline$\% 52.1$ & 213 & ذكر & \\
\hline$\% 1 \ldots$ & 409 & الإجمالي & \\
\hline \% or.r & 218 & المدينة & \multirow{3}{*}{ محل الاقامة } \\
\hline$\%$ ะ ..V & 191 & الريف & \\
\hline$\% 1 \ldots$ & 8.9 & الإجمالي & \\
\hline
\end{tabular}

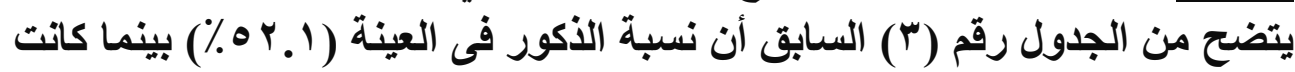
نسبة الإناث العينة يقيمـون في المدينة. *المتوسطات المرجحة والاتحرافات المعيارية لمتفيرات المدئة:

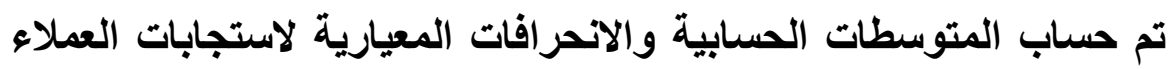

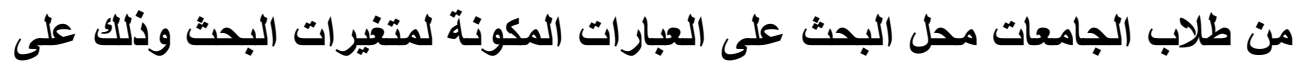

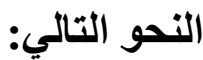

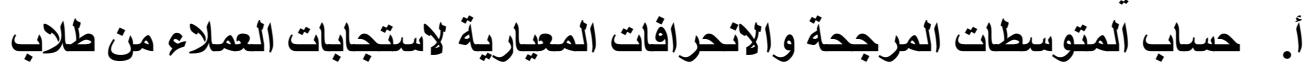
الجامعات على العبارات المكونة لأبعاد الخداع التسويقي الأربعة. البعد الأول: الخداع في المنتج: التبارات المكنه 


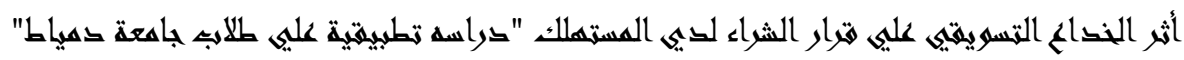

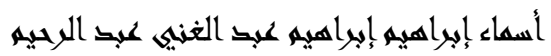

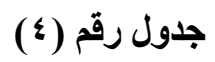

المتوسطات المرجحة والانحرافات المعيارية لاستجابات العملاء من طلاب الجامعات على ألى المئي

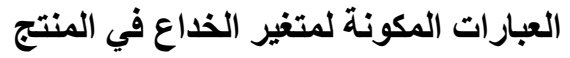

\begin{tabular}{|c|c|c|c|c|c|}
\hline النسبي & $\begin{array}{l}\text { الأهمية } \\
\text { النسبية } \\
\text { (\%) }\end{array}$ & المعياري & المرجح & العبارة المستخدمة & رقبم \\
\hline 1 & $\% \wedge \vee . \curlyvee$ & $\because \Delta V r$ & $\varepsilon . r \wedge \wedge$ & 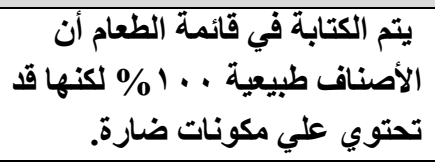 & 1 \\
\hline$r$ & $\% \wedge \vee .1$ & $.7 \leq 1$ & $\varepsilon . r \circ V$ & 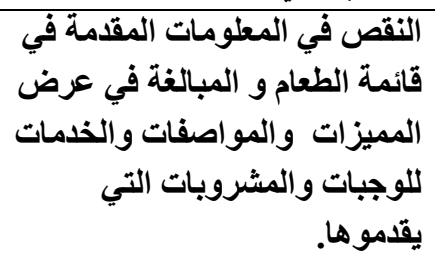 & r \\
\hline$r$ & $\% \wedge$ \% & $\because .7 \leqslant 1$ & $\varepsilon . r \varepsilon$. & 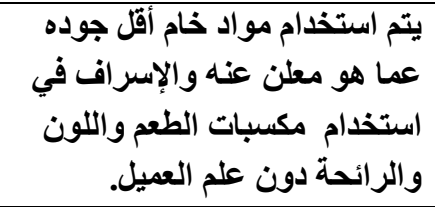 & $r$ \\
\hline & $\% \wedge \vee . r$ & $\cdot . \leqslant \vee \vee V$ & ס ט & في المنتج & \\
\hline
\end{tabular}

المصدر: من إعداد الباحث وفقاً لنتائج التحليل الإحصائي.

يوضح الجدول رقم (ع) السابق مدى إدراك العملاء من طلاب الجامعات للخداع

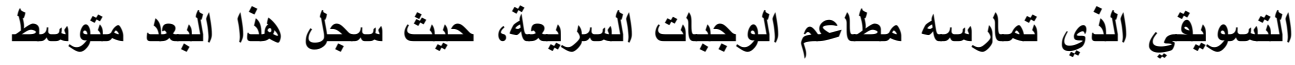

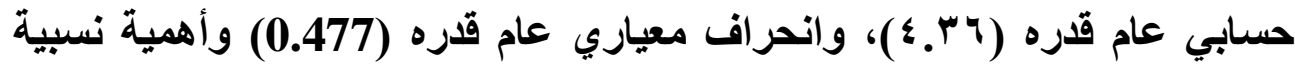

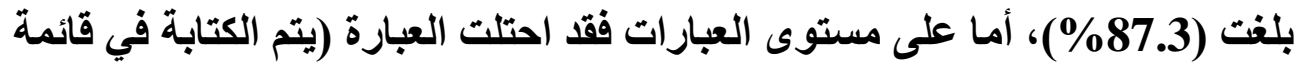

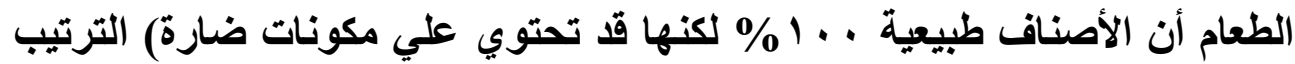

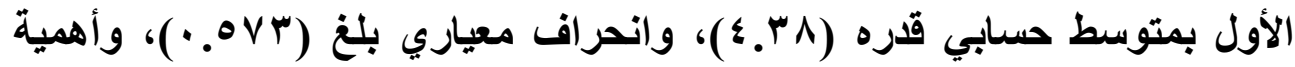

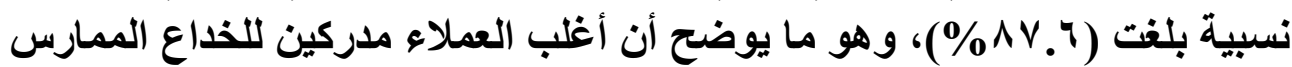
من قبل مقدمي الخدمة أثناء تحضير والمنتجات، بينما احتلث العبارة (يتم استخدام 


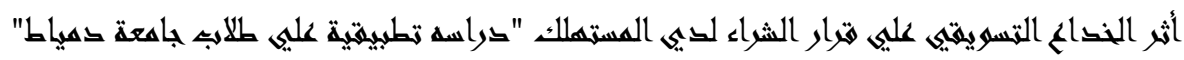

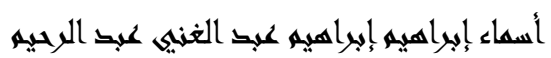

مواد خام أقل جوده عما هو معلن عنه والإسراف في استخدام مكسبات الطعم

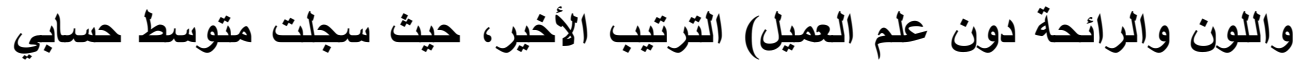

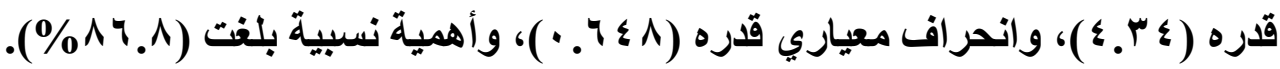

$$
\text { جدول رقم (0) }
$$

البعد الثاني: الخداع في السعر: وانجر:

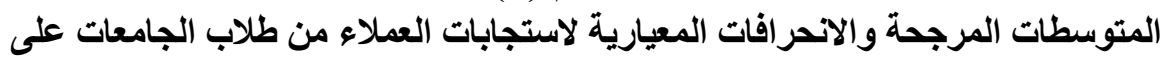

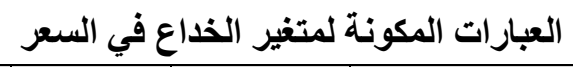

\begin{tabular}{|c|c|c|c|c|c|}
\hline النسبي بــبـ & 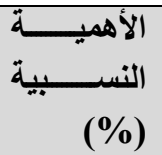 & الالحيـراف & المرجح & العبارة المستخدمة & رقم العبارة \\
\hline 1 & $\% \wedge \vee . \curlyvee$ & $\because 0 V \leq$ & ؟ & 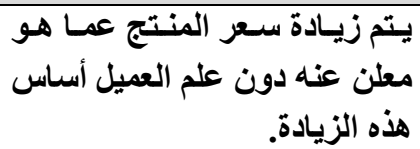 & $\varepsilon$ \\
\hline r & $\% \wedge \vee$ & צ & ט. & 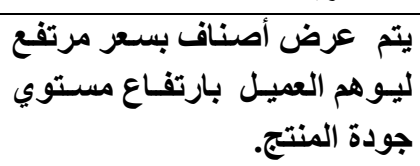 & 0 \\
\hline 7 & $\%^{\wedge} \varepsilon$ & $\because V \leq r$ & $\varepsilon . r$. & 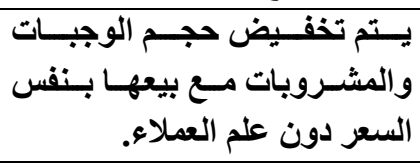 & 1 \\
\hline$\varepsilon$ & $\% \wedge$ ^ฯ. & $\cdot .7 \cdot 9$ & $\varepsilon . r Y$ & 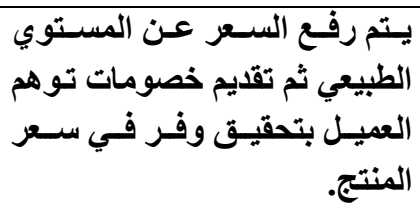 & v \\
\hline$r$ & $\% \wedge 4 . ૫$ & .977 & S.rT & 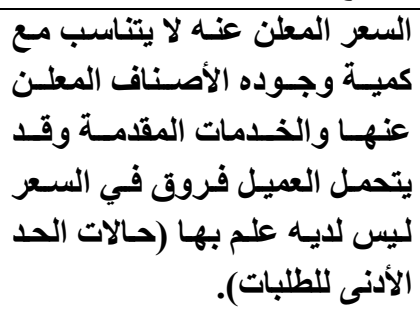 & $\wedge$ \\
\hline
\end{tabular}

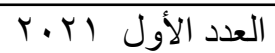




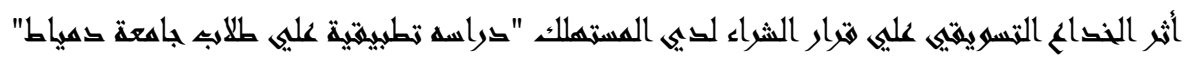

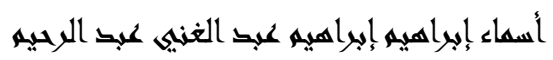

\begin{tabular}{|c|c|c|c|c|c|}
\hline النسبي & 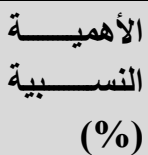 & الالحيـراف & المرجح & العبارة المستخدمة & رقم العبارة \\
\hline 0 & $\% \wedge 4$ &. .79. & \&.r. & 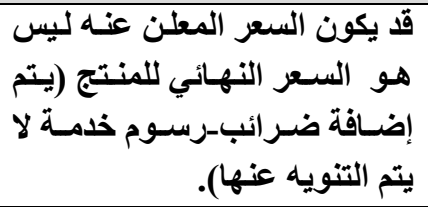 & 9 \\
\hline ----- & $\% \wedge ५ . \curlyvee$ & $\cdot \varepsilon+1$ & \&.r & \multicolumn{2}{|c|}{ الخداع في السعر } \\
\hline
\end{tabular}

المصدر: من إعداد الباحث وفقاً لنتائج التحليل الإحصائي.

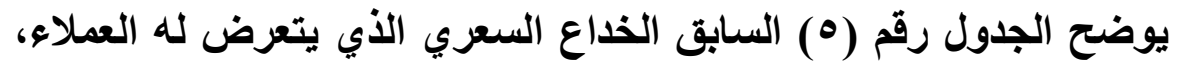

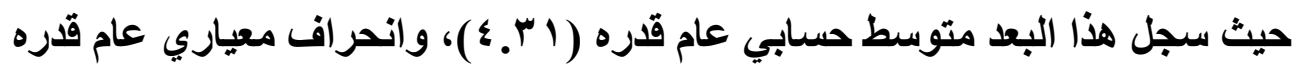

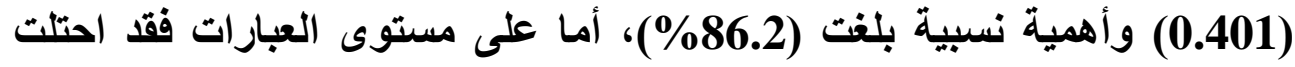

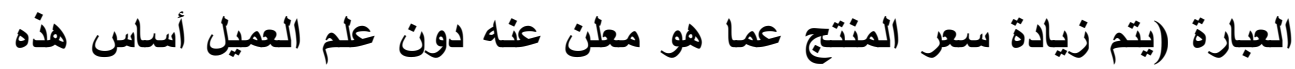

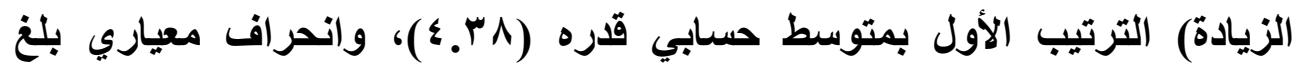

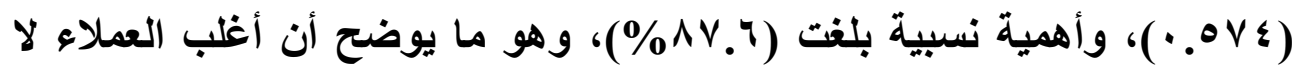

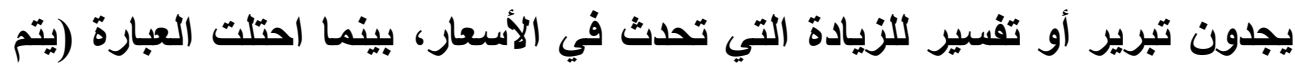
تخفيض حجم الوجبات والمشروبات مع بيعها بنفس السعر دون علم المبر العملاء)

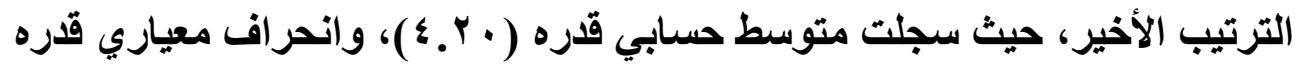

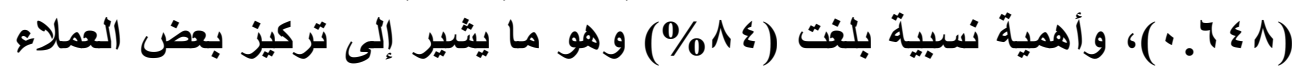
على سعر المنتج فقط دون ربط هذا السعر بحجم الصنف او او العبوة

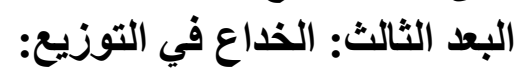




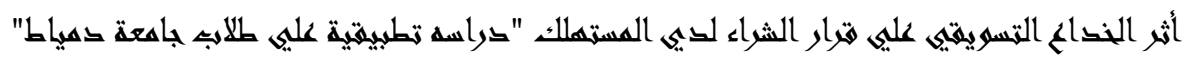

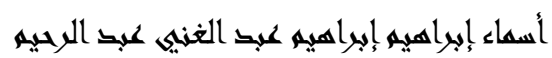

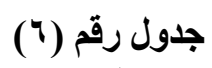

المتوسطات المرجحة والانحرافات المعيارية لاستجابات العملاء من طلاب الجامعات على الجي

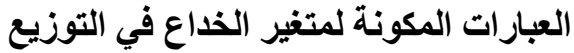

\begin{tabular}{|c|c|c|c|c|c|}
\hline النسبي & الأهمية النسبية & الانحراف & المرجح & العبارة المستخدمة & رقبارة \\
\hline$r$ & $\%{ }^{\wedge} 0_{0}\{$ & $\because V 70$ & $\varepsilon . Y V$ & |للك. & \\
\hline$\varepsilon$ & $\% \wedge r$ & $\because V \bullet \leq$ & ะ. & 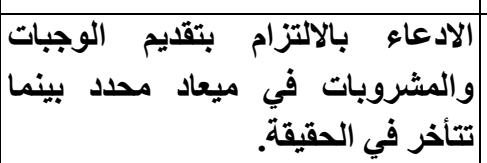 & 1 \\
\hline 1 & $\% \wedge$ \%. & $. V Y \leq$ & E.rY & 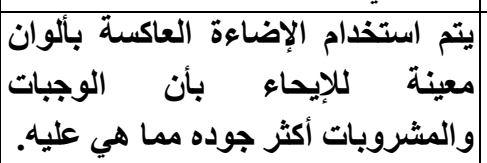 & 1 \\
\hline r & $\% \wedge 4$ &. VYr & \&.r. & 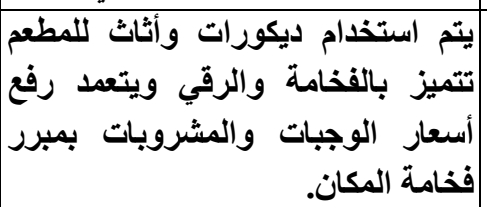 & 1 \\
\hline$r$ & $\% . \wedge \bullet . r$ & $\because \vee 99$ & צ. צ. & يتم بيع العينات المجانية التي يحصل & \\
\hline ----- & $\% \wedge \bullet, \wedge$ & $.07 r$ & $\varepsilon . r q$ & ـاع في التوزيع & \\
\hline
\end{tabular}

المصدر: من إعداد الباحث وفقاً لنتائج التحليل الإحصائي.

يوضح الجدول رقم (7) السابق مدى إدر الك العملاء للكنب و التضليل الذي الأي تمارسه

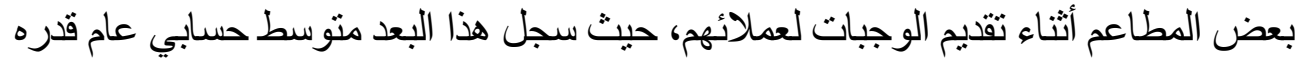

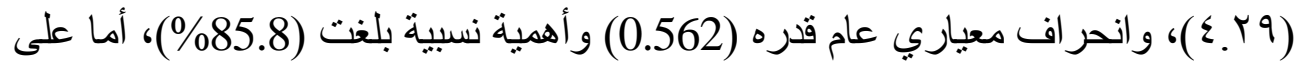

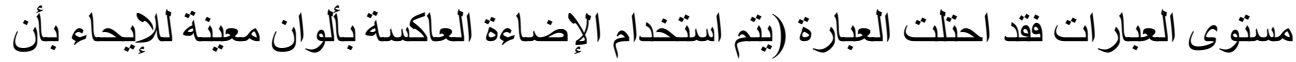

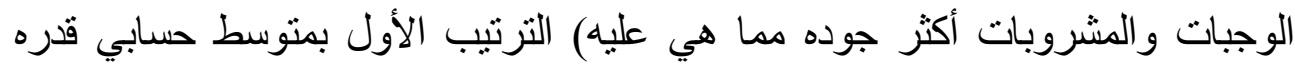




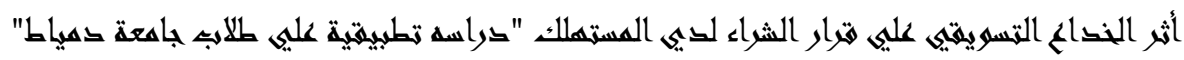

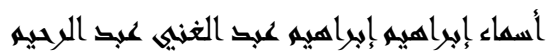

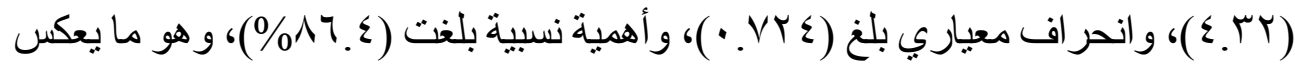

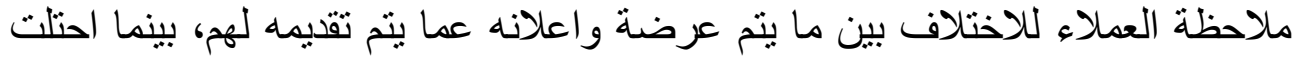

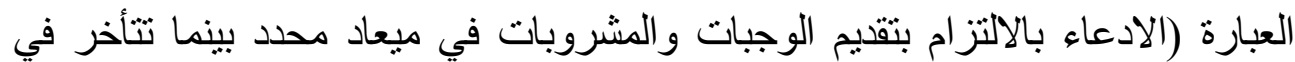

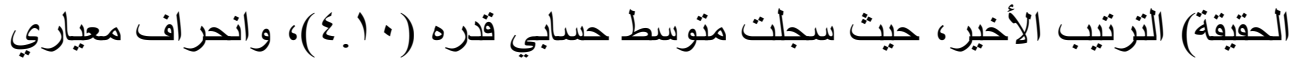

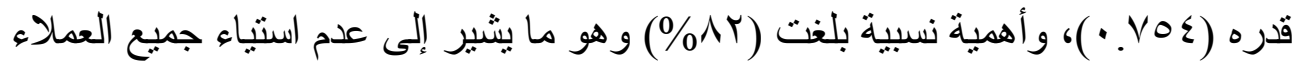

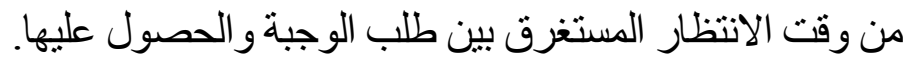
البعد الر ابع: الخداع في الترويج:

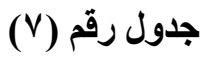

المتوسطات المرجحة والاتحرافات المعيارية لاستجابات العملاء من طلاب الجامعات على الجى

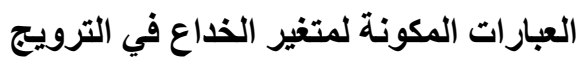

\begin{tabular}{|c|c|c|c|c|c|}
\hline النسبي & $\begin{array}{r}\text { الأهمية } \\
\text { النسبية } \\
\text { (\%) }\end{array}$ & المعياري & المرجح & العبارة المستخدمة & رقبم \\
\hline 0 & $\%^{\wedge} \varepsilon$ & $\because v q r$ & צ. צ. & 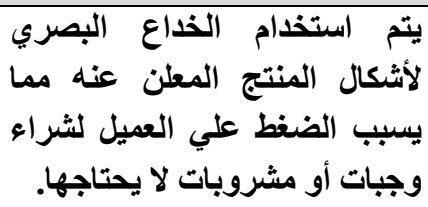 & 10 \\
\hline r & $\% \wedge$ \% & .94. & $\varepsilon . \mu \varepsilon$ & 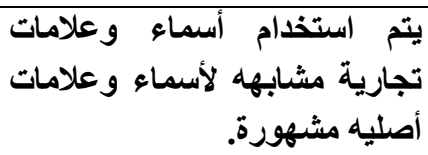 & 17 \\
\hline$r$ & $\% \wedge$ \%.० & $.7 \wedge 7$ & $\varepsilon . M Y V$ & 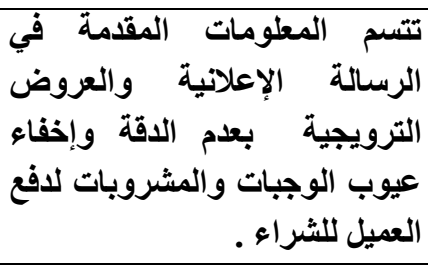 & IV \\
\hline 1 & $\% \wedge \wedge . \curlyvee$ & $\because v 00$ & 4.43 & 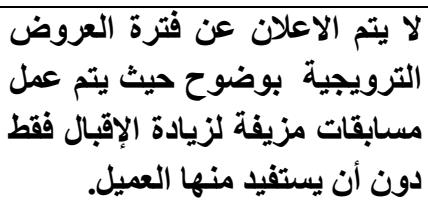 & 11 \\
\hline
\end{tabular}




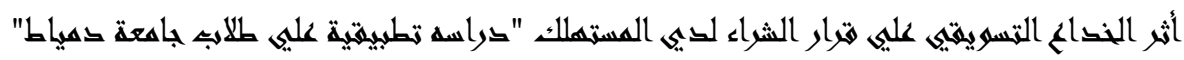

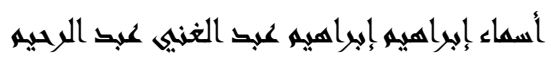

\begin{tabular}{|c|c|c|c|c|c|}
\hline$\varepsilon$ & $\% \wedge \neg$ & $\because V \leq$. & $\varepsilon . \mu$. & 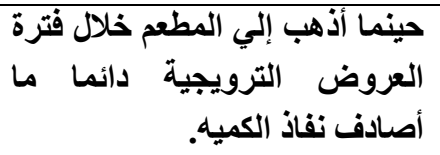 & 19 \\
\hline ---- & $\% \wedge$ & $\because \leqslant 9 \wedge$ & $\varepsilon . r$. & \multicolumn{2}{|c|}{ الخداع في الترويج } \\
\hline
\end{tabular}

المصدر: من إعداد الباحث وفقاً لنتائج التحليل الإحصائي.

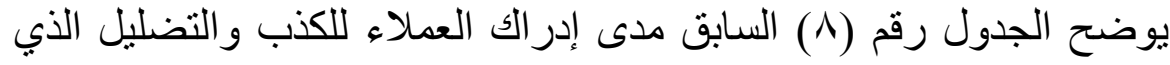

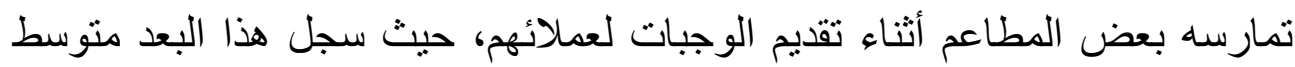

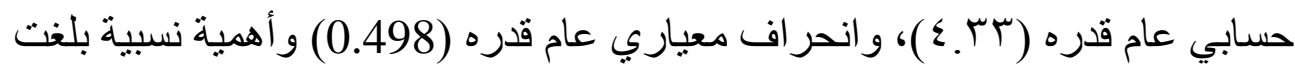

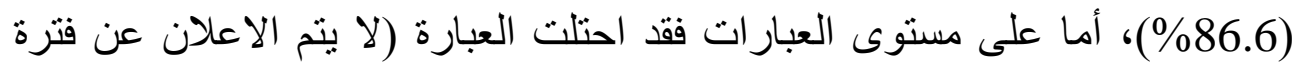

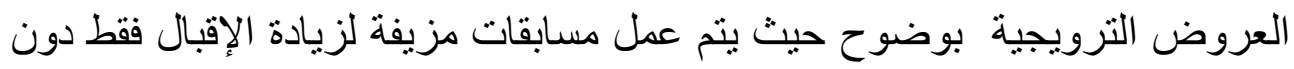

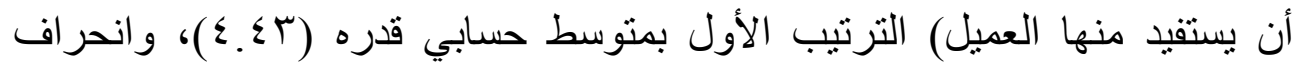

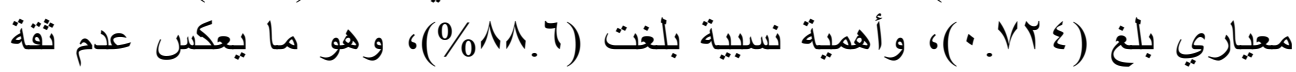

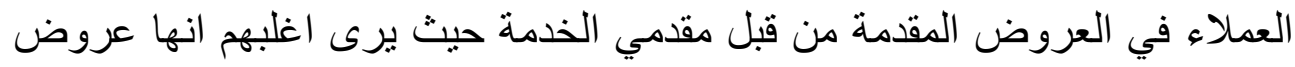

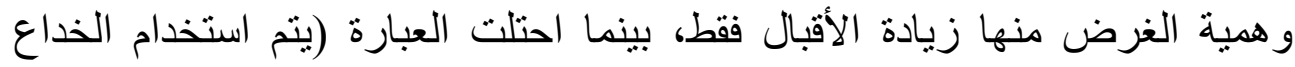

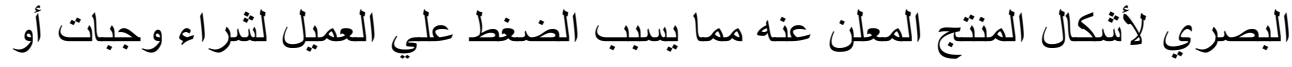

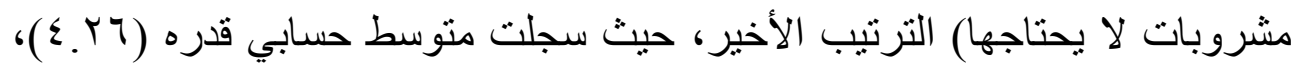

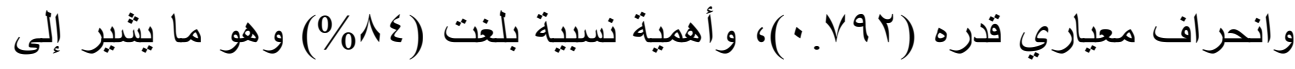
تعرض بعض العملاء للخداع النفسي والبصري واستجابتهم لذلك رغان رغم عدم احتياجهم لهذه المنتجات. هذا ويوضح الجدول رقم (9) التالي مقارنة بين المتوسطات الحسابية لأبعاد الخداع التسويقي. 


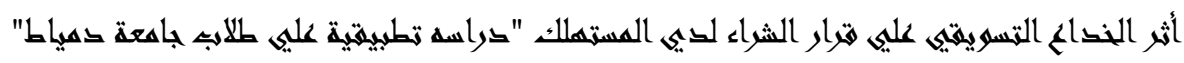

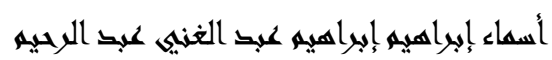

جدول رقم (9) جوالانحران

مقارنة بين المتوسطات المرجحة والانحر افات المعيارية لأبعاد الخداع التسويقي

\begin{tabular}{|c|c|c|c|c|}
\hline النسبي & $\begin{array}{c}\text { الأهمية النسبية } \\
\text { \% }\end{array}$ & الالاتحراف & المرجح & المتغير \\
\hline 1 & $\%{ }^{\wedge \wedge \vee} . \Gamma$ & $\because \leqslant V \vee V$ & $\varepsilon, 490$ & الخداع في المنتج \\
\hline 2 & $\%$ & $\cdot . \varepsilon \cdot 1$ & \&.r & الخداع في السعر \\
\hline 4 & $\% \%^{\wedge \bullet} . \wedge$ & .074 & $\varepsilon .49$ & الخداع في التوزيع \\
\hline 3 & $\% \wedge 4$ &..$\leqslant 91$ & $\varepsilon . r$. & الخداع في الترويج \\
\hline
\end{tabular}

المصدر: من إعداد الباحث وفتًا لنتائج التحليل الإحصائي.

يتضح من الجدول السابق أن نرتيب أبعاد الخداع التسويقي حسب الإبـ الأهمية

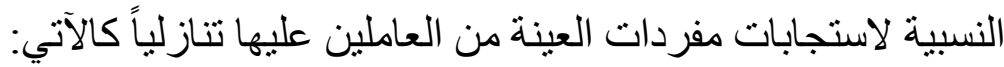

$$
\text { الخداع في المنتج. الخداع في السعر. الخداع في الترويج. }
$$

ب. حساب المتوسطات المرجحة والانحرافات المعيارية لاستجابات العملاء على العبار ات المكونة لأبعاد قرار الثر اء الخدو الخمسة. البعد الأول: مرحلة إدر الك الحاجة:

\begin{tabular}{|c|c|c|c|c|c|}
\hline النسبي & الأهبية & المعياري & المرجح & العبارة المستخدمة & العبارة \\
\hline 1 & $\%^{\wedge \vee}$ & - & \&.To & المطاعم. قبل التعامل مع هذه & $r$. \\
\hline
\end{tabular}

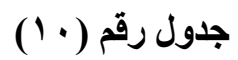

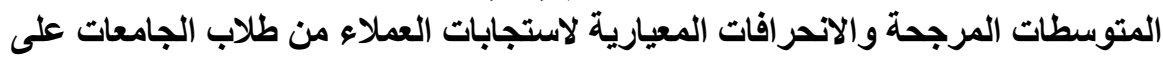

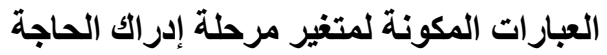




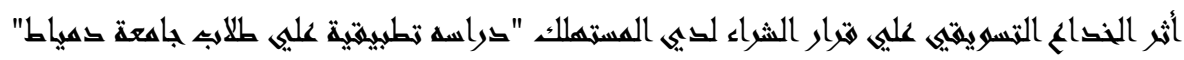

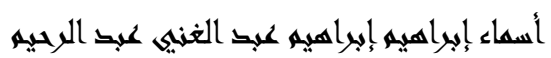

\begin{tabular}{|c|c|c|c|c|c|}
\hline$r$ & $\% \wedge \neg .7$ & .709 & $\varepsilon . r r$ & مذبه المطاعم لرغباتي. أشعر بأنها غير & Y \\
\hline$r$ & $\% \wedge \bullet . \varepsilon$ & $\because \vee \curlyvee$ & $\varepsilon . r V$ & 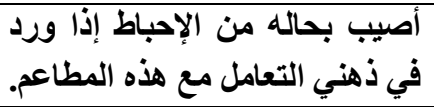 & $r r$ \\
\hline-- & $\% \wedge \neg . \varepsilon$ & $\because \leqslant \wedge 7$ & $\varepsilon . r Y$ & إدراك الحاجة & \\
\hline
\end{tabular}

المصدر: من إعداد الباحث وفقاً لنتائج التحليل الإحصائي.

بوضح الجدول رقم ( (1) السابق مدى إدرالك العميل لاحتياجاته ورغباته

و الصورة الذهنية المكونة لديه بشأن المطاعم التي سبق وتعامل معها، حيث سجل هذا البعد متوسط حسابي عام قدره (Yr.\&)، و انحراف معياري عام قدره (0.486) و أهمية نسبية بلغت (86.4\%)، أما على مستوى العبار ات فقد احتلت العبارة (التردد قبل التعامل مع هذه

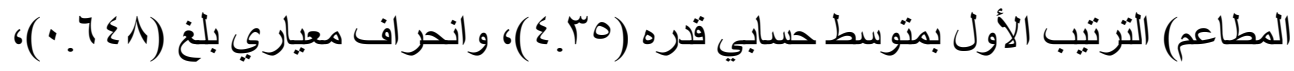
وأهمية نسبية بلغت (NV)\%)، وهو ما بشير إلى شك العميل في قدرة هذه المطاعم على إثباع احتباجاته ور غباته، بينما احتلت العبارة (أصبب بحاله من الإحباط إذا ورد في ذهني

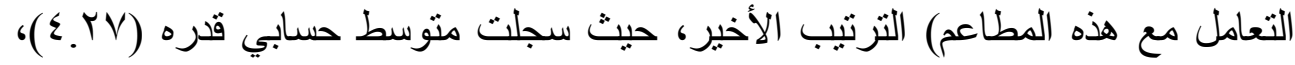

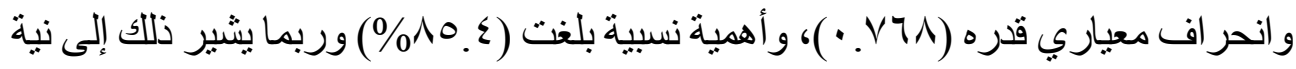
بعض العملاء استمر ار التعامل مع هذه المطاعم على الر غم من عدم ثقتهم بها. البعد الثاني: مرحلة المقارنة بين البدائل:

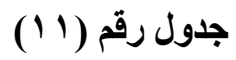

المتوسطات المرجحة والانحرافات المعيارية لاستجابات العملاء من طلاب الجامعات على

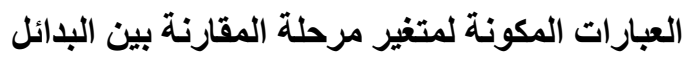

\begin{tabular}{|c|c|c|c|c|c|}
\hline التسبيب & $\begin{array}{l}\text { الأهمية } \\
\text { (النسبية }\end{array}$ & الاتحرياري & المرجت المرجط & العبارة المستخدمة & رقم \\
\hline$r$ & $\% \wedge \theta$ & $\because \wedge Y l$ & $\varepsilon . r_{0}$ & 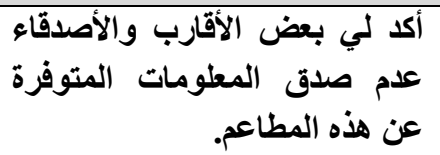 & rr \\
\hline
\end{tabular}

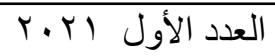




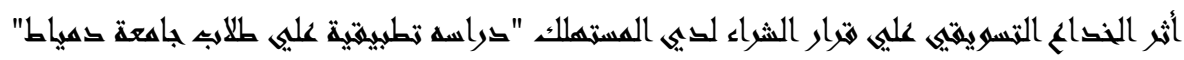

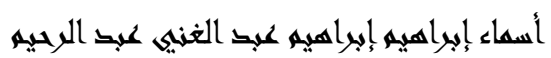

\begin{tabular}{|c|c|c|c|c|c|}
\hline$r$ & $\% \wedge \neg$ & $\because$ VYr & $\varepsilon . r$. & 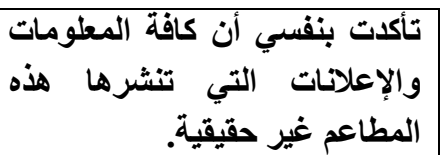 & Y $\varepsilon$ \\
\hline 1 & $\% \wedge \neg . \varepsilon$ & .779 & $\varepsilon . M r$ & أصبحت ذو خبره لأتجنب مثّل هذه & ro \\
\hline . & $\% \wedge \bullet . \wedge$ & $\because 0 \leqslant 9$ & $\varepsilon . Y q$ & المقارنة بين البدائل & \\
\hline
\end{tabular}

المصدر: من إعداد الباحث وفةًا لتتائج التحليل الإحصائي.

يوضتح الجدول رقم (1) السابق مدى قدرة العميل على المقارنة بين المطاعم المتاحة لايه و اختيار ما بناسبه منها، حيث سجل هذا البعد منوسط حسابي عام قدره (9 . ؟))، وانحر اف معياري عام قدره (0.549) وأهمية نسبية بلغت (85.8\%)، أما على هلى مستوى العبار ات فقد احتلت العبارة (أصبحت ذو خبره لأتجنب مثل هذه المطاعم بسبب تعاملي السابق) الترتيب الأول بمتوسط حسابي قدره (Y..؟)، وانحراف

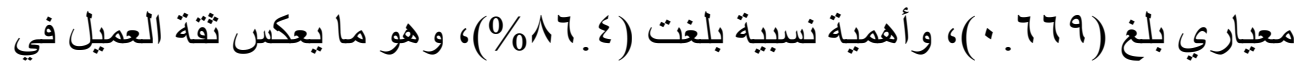
قدرته على استبعاد المطاعم التي له تجارب سلبية معها، بينما احتلت العبارة (تأكدت بنفسي أن كافة المعلومات و الإعلانات التي تتشر ها هذه المطاعم غير حقيقية) الترتيب الثاني بمتوسط حسابي قدره ( • ب.؟)، و انحر اف معياري عام قدره (0.722) و أهمية نسبية بلغت (86\%)، أما العبارة (أكد لي بعض الأقارب والأصدقاء عدم صدق المعلومات المتوفرة عن هذه المطاعم) فقد احتلت الترتيب الأخير، حيث سجلت

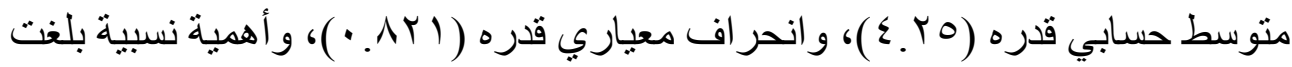
(10\%) وربما بشير ذلك اعتماد العمبد على رأي الأخرين إلى جانب تجاربه الثخصية السابقة في تكوين رأيه وصورته الذهنية الخاصة بهذه المطاعم. البعد الثالث: مرحلة تقييم البدائل: 


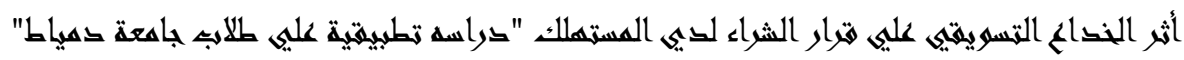

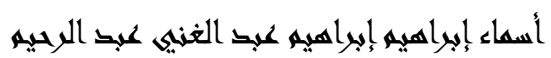

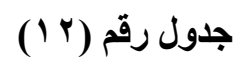

المتوسطات المرجحة والانحرافات المعيارية لاستجابات العملاء من طلاب الجامعات على العي

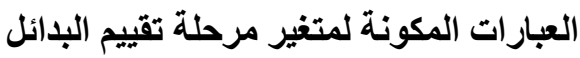

\begin{tabular}{|c|c|c|c|c|c|}
\hline النسبي & $\begin{array}{l}\text { الأهمية } \\
\text { النسبية } \\
\text { (\%) }\end{array}$ & المعياري & المرجح & العبارة المستخدمة & رقبم \\
\hline r & $\% \wedge 0.7$ & $\because V \leqslant Y$ & \&.Y & والمضانلة، تحديد المطاعم الأخرى الخادعة التي & Y \\
\hline$r$ & $\%^{\wedge} \varepsilon_{.}{ }^{\top}$ & $\cdot \wedge \cdot 1$ & $\varepsilon . Y \mu$ & 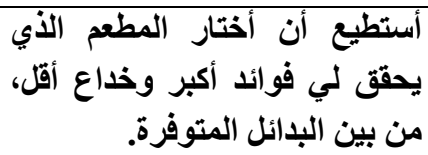 & rV \\
\hline 1 & $\%$ & $\because v \cdot v$ & $\varepsilon . r$. & 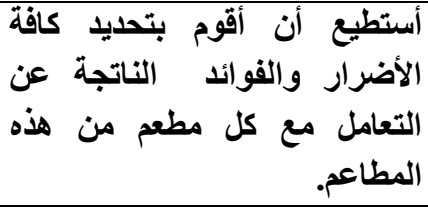 & rA \\
\hline--- & $\% \wedge \bullet . \varepsilon$ & $\cdot .7 \cdot \varepsilon$ & $\varepsilon . r V$ & تقييم البدائل & \\
\hline
\end{tabular}

المصدر: من إعداد الباحث وفقاً لنتائج التحليل الإحصائي.

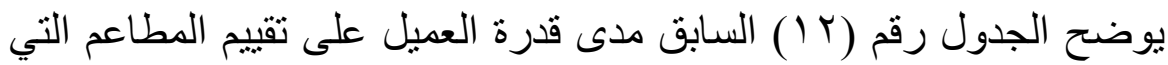

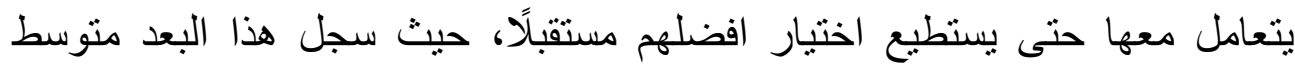

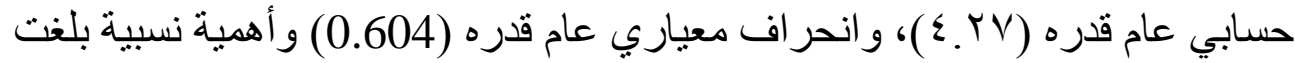

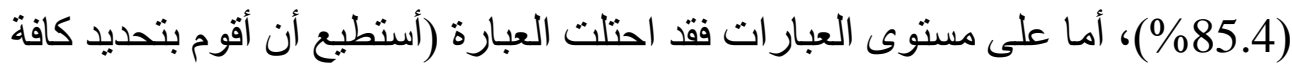

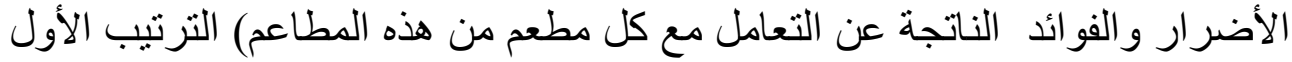

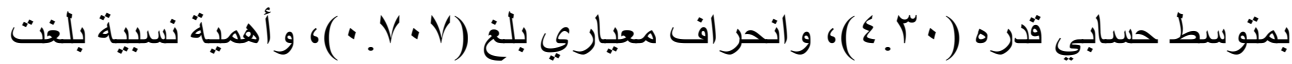

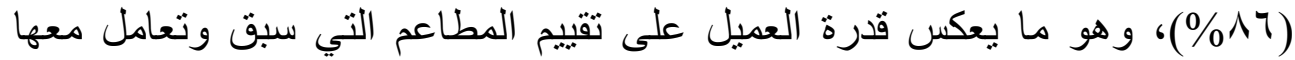

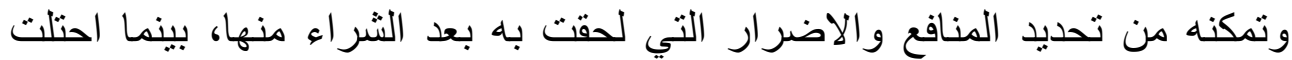

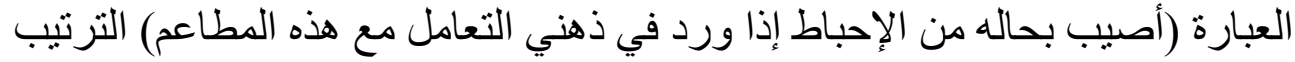




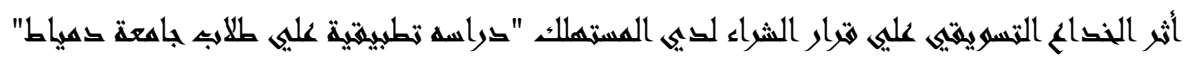

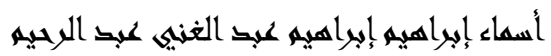

الأخير، حيث سجلت متوسط حسابي قدره (YV.Y.)، و وانحراف معياري قدره

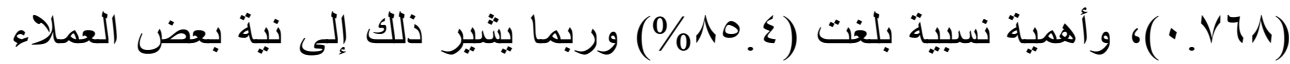
استمر ار التعامل مع هذه المطاعم على الرغم من عدم ثقتهم الكاملة بها.

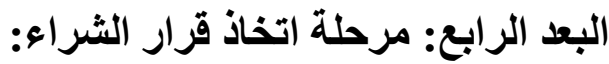

جلول

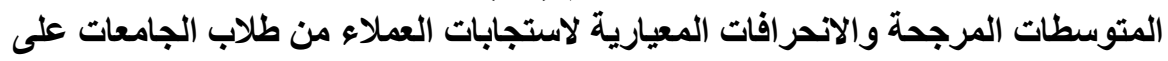

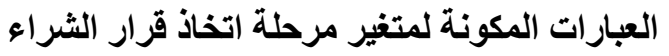

\begin{tabular}{|c|c|c|c|c|c|}
\hline النسبي & $\begin{array}{l}\text { الأهمية } \\
\text { النسبية } \\
\text { (\%) }\end{array}$ & المعياري & المرجح & العبارة المستخدمة & العبارة \\
\hline$\mu$ & $\% \wedge \varepsilon .7$ & F & 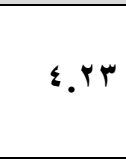 & فالأخي المرتبة الثانية بعد المطاعم والمضلة & rq \\
\hline 1 & $\% \wedge 0.0$ &.$V 7 V$ & 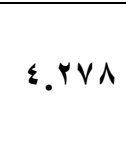 & ألخيادانا اضطر للتعامل مع المطاعم للظروف وضيق & $r$. \\
\hline$r$ & $\% \wedge 0 . r$ & $\because \vee \vee q$ & צ. & مع هذه المطاعم. أكون اضطررت للتعامل & r \\
\hline ---- & $\%{ }^{\wedge \bullet} \vee \vee$ & $\because \diamond \wedge \wedge$ & $\varepsilon . r \wedge \wedge$ & اتخاذ قرار الشراء & \\
\hline
\end{tabular}

المصدر: من إعداد الباحث وفقاً لنتائج التحليل الإحصائي.

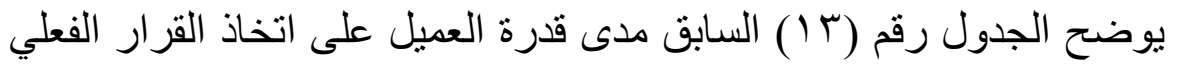

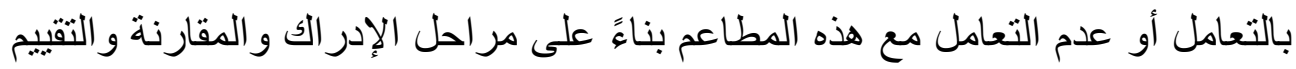

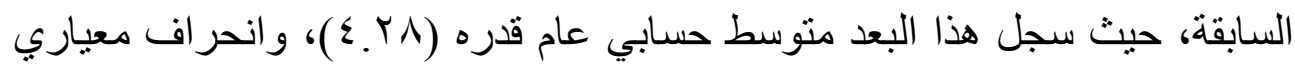

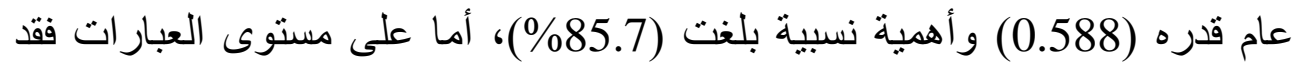

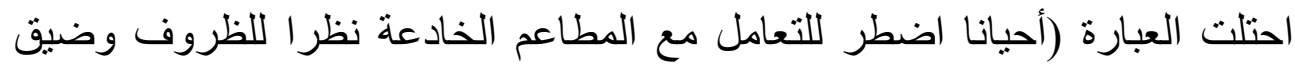

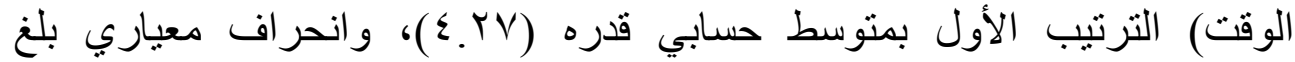

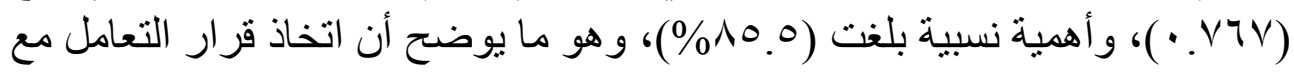




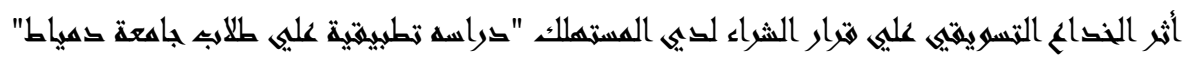

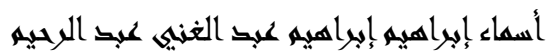

هذه المطاعم الخادعة من قبل العملاء يرجع إلى عو امل وظروف قهرية وليس لتقتهم

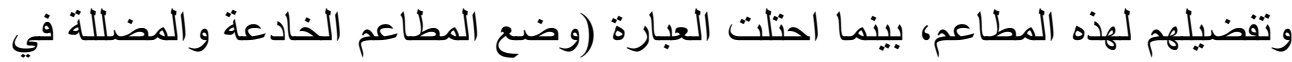

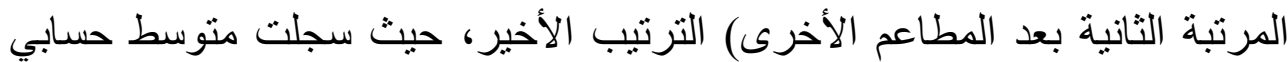

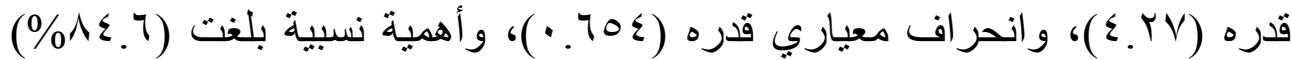
و هو ما يعكس بأنه على الرغم من ادر الك العملاء للخداع الذي تمارسه هذه هذه المطاعم إلا أن بعض هؤ لاء العملاء لا يصنف بلائه تلك المطاعم بناءً على هذا المعيار.

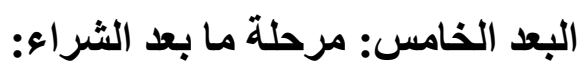

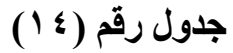

المتوسطات المرجحة والانحرافات المعيارية لاستجابات العملاء من طلاب الجامعات على الع العي

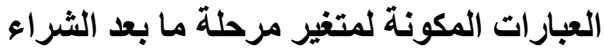

\begin{tabular}{|c|c|c|c|c|c|}
\hline الن التببي & $\begin{array}{r}\text { الأهمبية } \\
\text { النسبية } \\
\text { (\%) }\end{array}$ & المعياري & المرجح & العبارة المستخدمة & رقبم \\
\hline r & $\% \wedge$ \% &. $.7 \vee \wedge$ & $\varepsilon . r Y V$ & لأنها خارج توقعاعم تثعرني بعدم الرضا & $r$ \\
\hline 1 & $\% \wedge \vee . \bullet$ & .910 & $\varepsilon . \mu V V$ & بعدم التعامل مع هذه المطاعم. أعرفهم & $r$ \\
\hline$r$ & $\% \wedge \bullet . \wedge$ & $\cdot V \leqslant 0$ & $\varepsilon . Y q$ & 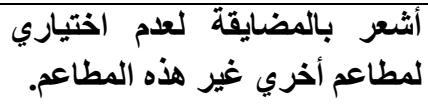 & $\Gamma \varepsilon$ \\
\hline ----- & $\% \wedge$ \%. & ـ & \&.Tr & لثراء & \\
\hline
\end{tabular}

\section{المصدر: من إعداد الباحث وفقاً لنتائج التحليل الإحصائي.}

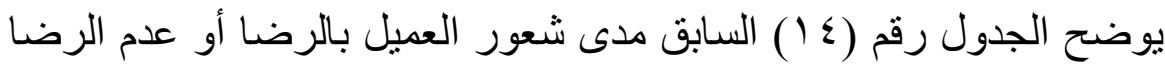
بعد إتمام عملية الثراء من هذه المطاعم، حيث سجل هذا البعد متوسط حسابي عام

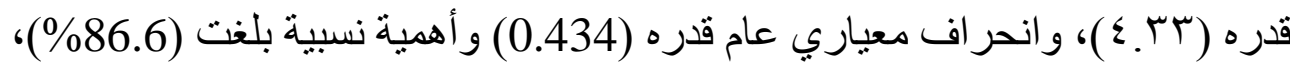

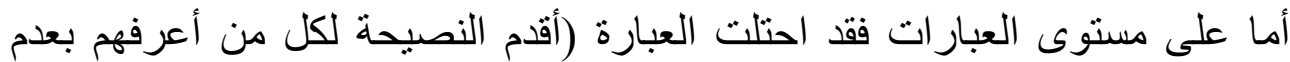

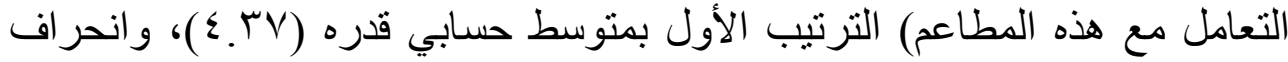

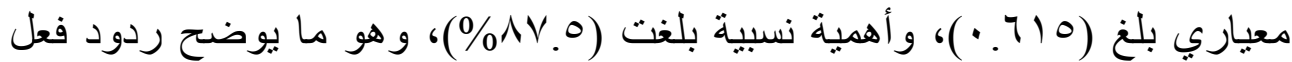




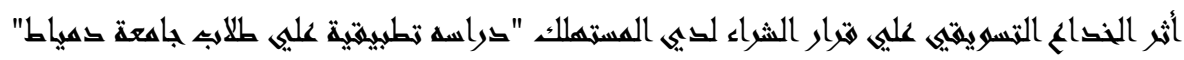

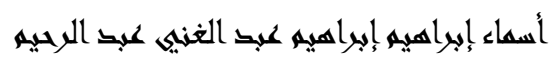

العملاء في حالة عدم رضاهم عن التجربة ورغبتهم في تحذير كل معارفهم من

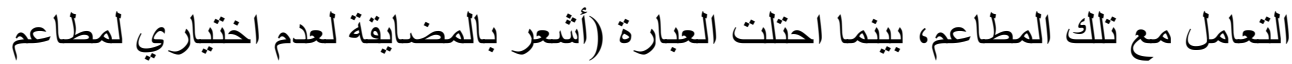

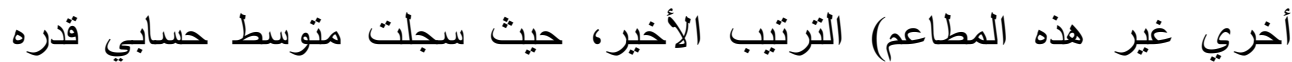

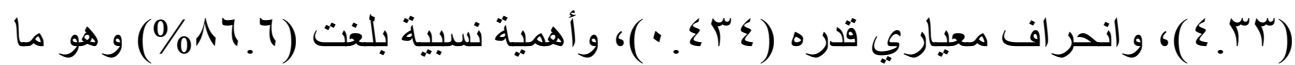

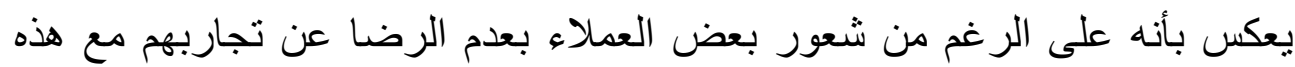

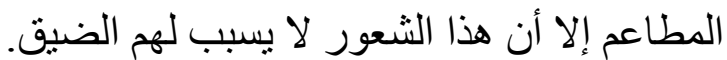
هذا ويوضح الجدول رقم (10) التالي مقارنة بين المتوسطات الحسابية

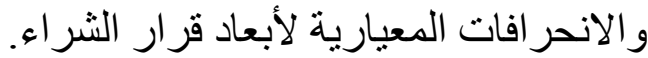

$$
\text { جدول رقم (10) }
$$

مقارنة بين المتوسطات المرجحة والاتحرافات المعيارية لأبعاد قرار الثراء

\begin{tabular}{|c|c|c|c|c|c|}
\hline النسبي & $\begin{array}{r}\text { الأهمية النسبية } \\
\text { \% }\end{array}$ & المعياري & المرجح & المتغير & b \\
\hline 2 & $\%$ \%ฯ. . & $\because \leqslant \wedge 4$ & $\varepsilon . \mu r$ & مرحلة ادراك الحاجة & 1 \\
\hline 3 & $\% \%^{\wedge \bullet} . \wedge$ & $\because 0 \leqslant 9$ & $\varepsilon . q^{2}$ & مرحلة المقارنة بين البدائل & r \\
\hline 5 & $\% \%^{\wedge 0 . \xi}$ & $.9 \cdot \varepsilon$ & $\varepsilon . Y V$ & مرحلة تقييم البدائل & $r$ \\
\hline 4 & $\% \%^{\wedge \bullet} . \vee$ & $\because 0 \wedge \wedge$ & $\varepsilon .{ }^{\varepsilon \wedge}$ & مرحلة اتخاذ قرار الشراء & $\varepsilon$ \\
\hline 1 & $\%$ & $\cdot . \leqslant \xi \leqslant$ & צ.rr & مرحلة مـا بعد الثراء & 0 \\
\hline
\end{tabular}

المصدر: من إعداد الباحث وفقًا لتتائج التحليل الإحصائي. يتضح من الجدول السابق أن ترتيب أبعاد قرار الثراء حسب الإبـ الأهمية النسبية لاستجابات مفردات العينة من العاملين عليها تناز لياً كالآتي:

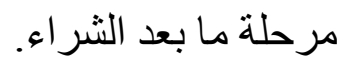

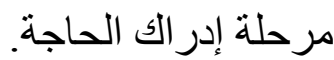

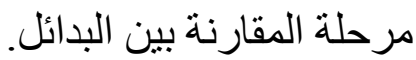

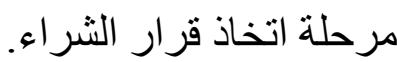

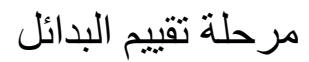
*جو هرية الفروق بين العملاء فيما يتعلق باستجاباتهم لمتغير ات البحث: 


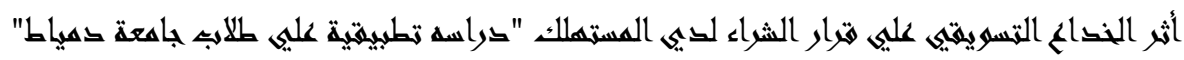

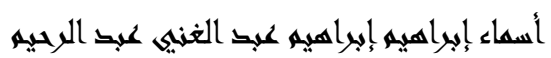

أ. جوهرية الفروق بين العملاء (من طلاب الجامعات) فيما يتعلق باستجاباتهم لأبعاد الخداع التسويقي (المتغير المستقل):

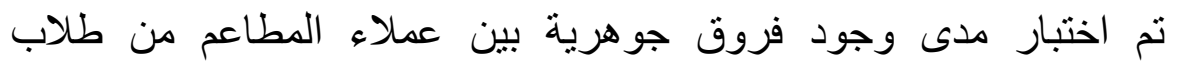
الجامعات فيما يتعلق باستجاباتهم لأبعاد الخداع التسويقي (الخداع في المنتج، الخداع

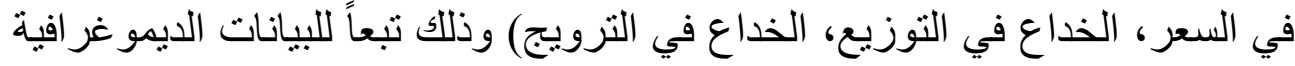

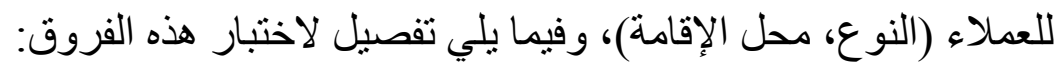

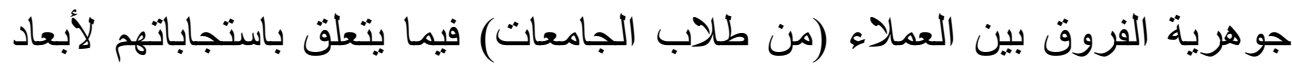

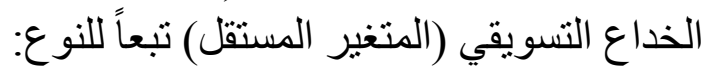

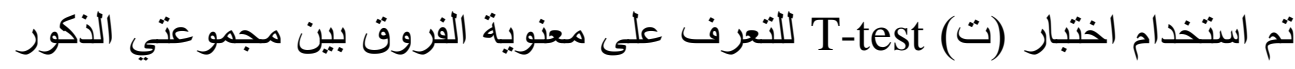

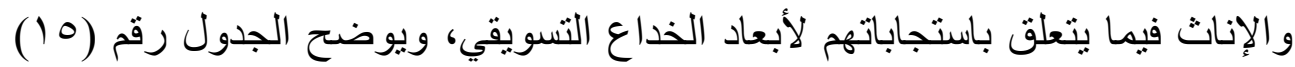
نتائج هذا الاختبار.

\section{جدول رقم (1 17 )}

اختبار (ت) جوهرية الفروق بين استجابات الذكور والإناث لأبعاد الخداع التسويقي

\begin{tabular}{|c|c|c|c|c|c|c|}
\hline \multicolumn{2}{|c|}{ اختبار (ت) T-test } & \multirow{2}{*}{ الانحراف } & \multirow{2}{*}{ الحستوسطي } & \multirow{2}{*}{ عداهدات } & \multirow{2}{*}{ النوع } & \multirow{2}{*}{ المتغير } \\
\hline مستوى المعنوية & قيمة * & & & & & \\
\hline \multirow{2}{*}{$\because r r$} & \multirow{2}{*}{ r. rVo } & $\cdot . \leqslant \wedge$ & \&.\&Y & 197 & أنثى & \multirow{2}{*}{ الثنتج الخداع في } \\
\hline & &. .570 & \&.Tा & YIT & ذكر & \\
\hline \multirow{2}{*}{$\because \varepsilon \cdot 1$} & \multirow{2}{*}{$\cdot \wedge \leqslant 1-$} & $\cdot . \leqslant r$ & \&.417 & 197 & أنثى & \multirow{2}{*}{ السعراع في } \\
\hline & & - & $\varepsilon . r \leqslant 9$ & rir & ذكر & \\
\hline \multirow{2}{*}{ - } & \multirow{2}{*}{$1.1 \cdot \Lambda_{-}$} & $\cdot . T \cdot Y$ & E.YTY & 197 & أنثى & \multirow{2}{*}{ التوزيع في } \\
\hline & &.$O Y Y$ & \&.YYT & YIT & ذكر & \\
\hline \multirow{2}{*}{ ه } & \multirow{2}{*}{$1 . \leqslant 9 \Lambda_{-}$} & $.0 Y \Lambda$ & \&.Y & 197 & أنثى & \multirow{2}{*}{ الترويج الخداع في } \\
\hline & &..$\leqslant 7 V$ & \& & riT & ذكر & \\
\hline
\end{tabular}

المصدر: من إعداد الباحث وفقاً لنتائج التحليل الإحصائي.

*' تثير الإثـارة (-) في قيمة (T) إلى أن الفروق لصالح المجمو عة الثانية (الذكور)، امـا إذا كانت الفروق لصالح

المجمو عة الأولى (الإناث) ففي هذه الحالة ستكون الإثـارة (+).

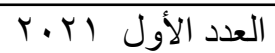




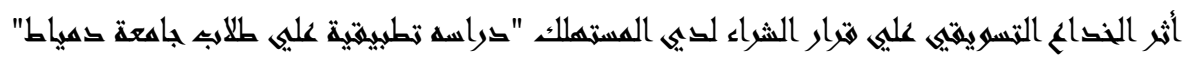

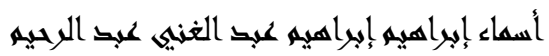

$$
\text { يتضح من الجدول رقم (7 ا ( ) ما يلي: }
$$

وجود فروق ذات دلالة معنوية بين استجابات الاكور والإناث فيما يتعلق

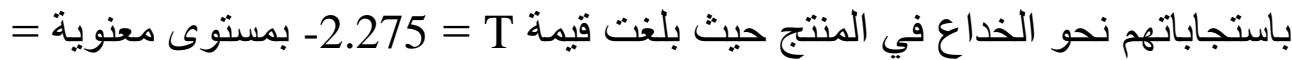

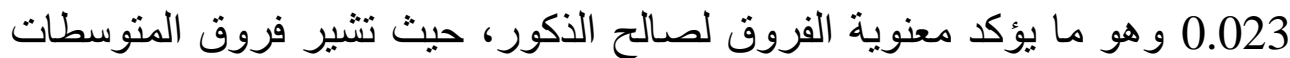
إلى أن مفردات العينة من الذكور هم أكثر إدر اكاً للخداع في المنتج من الإناث.

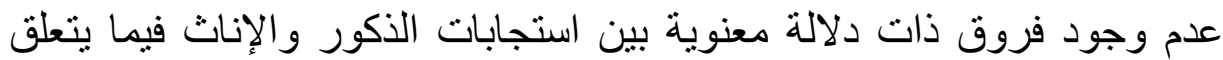
باستجاباتهم نحو الخداع في السعر حيث بلغت قيمة 0.401 و هو ما يؤكد عدم معنوية الفروق.

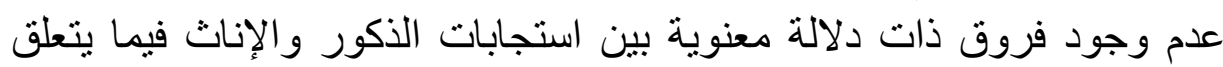

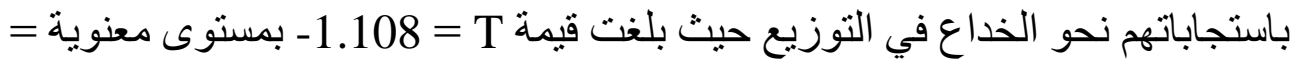
0.268 و هو ما يؤكد عدم معنوية الفروق. عدم وجود فروق ذات دلالة معنوية بين استجابات الذكور والإناث فيما يتعلق باستجاباتهم نحو الخداع في الترويج حيث بلغت قيمة

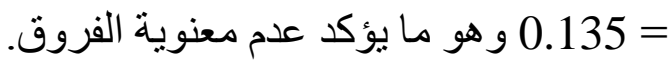
ا ـ جو هرية الفروق بين العملاء (من طلاب الجامعات) فيما يتعلق باستجاباتهم لأبعاد الخداع التسويقي (المتغير المستقل) تبعاً لمحل الإقامة: تم استخدام اختبار (ت) T-test للتعرف على معنوية الفروق بين العملاء (من طلاب التعابة

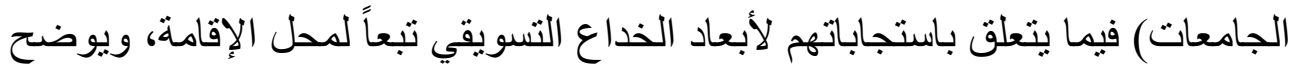

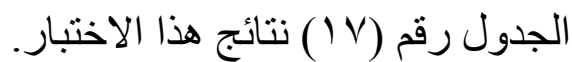

\section{جدول رقم (IV)}

اختبار (ت) جوهرية الفروق بين العملاء لأبعاد الخداع التسويقي تبعاً لمحل الإقامة

\begin{tabular}{|c|c|c|c|c|c|c|}
\hline \multicolumn{2}{|c|}{ اختبار (ت) T-test } & \multirow{2}{*}{ الانعراف } & \multirow{2}{*}{ المستوسطي } & \multirow{2}{*}{ عدد } & \multirow{2}{*}{ محل الإقامة } & \multirow{2}{*}{ المتغير } \\
\hline مستوى المعنوية & قيمة T T & & & & & \\
\hline \multirow{2}{*}{.104} & \multirow{2}{*}{$1 . \varepsilon r r$} & $\because \varepsilon \wedge \varepsilon$ & \&.rqV & YIA & المدينة & الخداع في \\
\hline & & $\because \leqslant 7 \wedge$ & $\varepsilon . r p q$ & 191 & الريف & المنتج \\
\hline $.91 \mathrm{~V}$ & $.1 \cdot \varepsilon=$ & $\because \leqslant 1 \%$ & \&.Mr & Y\A & المدينة & الخداع في \\
\hline
\end{tabular}




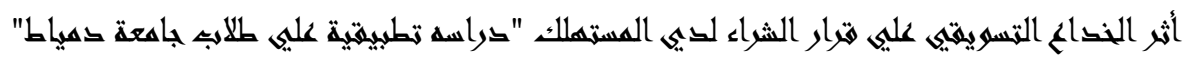

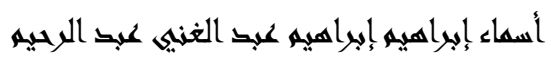

\begin{tabular}{|c|c|c|c|c|c|c|}
\hline & & $\cdot r \wedge \wedge$ & \&.\$Y & 191 & الريف & السعر \\
\hline \multirow{2}{*}{ ד } & \multirow{2}{*}{$\because \wedge 0}$. & .017 & \&.Y17 & $Y \backslash \Lambda$ & المدينة & \multirow{2}{*}{ التذاع في } \\
\hline & &. .711 & $\varepsilon .779$ & 191 & الريف & \\
\hline \multirow{2}{*}{$\because \wedge r$} & \multirow{2}{*}{$\because 9 \wedge 0$} & $\because \leqslant 90$ & $\varepsilon . \mu, \varepsilon$ & Y\A & المدينة & \multirow{2}{*}{ الترويج في في } \\
\hline & & $\because 0, r$ & $\varepsilon . \mu$ & 191 & الريف & \\
\hline
\end{tabular}

المصدر: من إعداد الباحث وفقاً لنتائج التحليل الإحصائي.

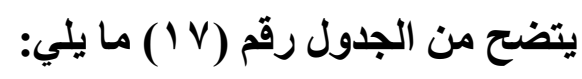

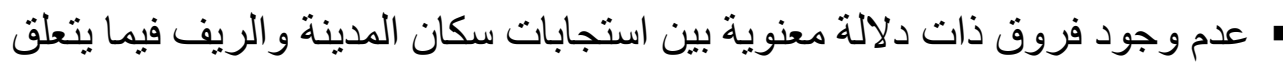
بإدر اكهم للخداع في المنتج حيث بلغت قيمة T 1.432 = 1.43 وهو ما يؤكد عدم معنوية الفروق. " عدم وجود فروق ذات دلالة معنوية بين استجابات سكان المدينة و الريف فيما يتعلق بإدر اكهم للخداع في السعر حيث بلغت قيمة T = = 0.104- بمستوى معنوية = 0.917 وهو ما يؤكد عدم معنوية الفروق.

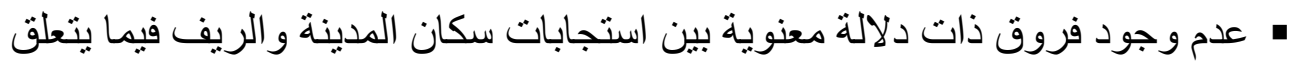

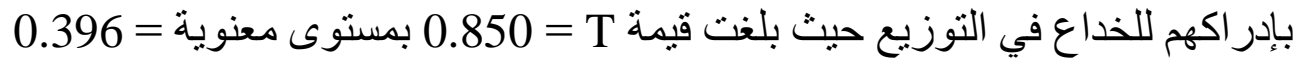
وهو ما يؤكد عدم معنوية الفروق. عدم وجود فروق ذات دلالة معنوية بين استجابات سكان المدينة و الريف فيما يتعلق بإدر اكهم للخداع في الترويج حيث بلغت قيمة T = 0.985 بمستوى معنوية = 0.082 وهو ما يؤكد عدم معنوية الفروق. ب. جوهرية الفروق بين العملاء (من طلاب الجامعات) فيما يتعلق باستجاباتهم قرار الثراء (المتغير التابع): تم اختبار مدى وجود فروق جوهرية بين عملاء المطاعم من طلاب الجامعات فيما

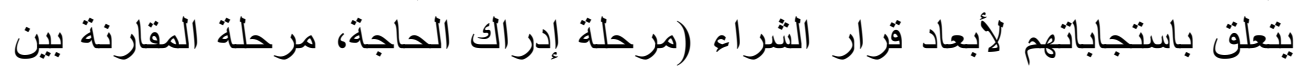

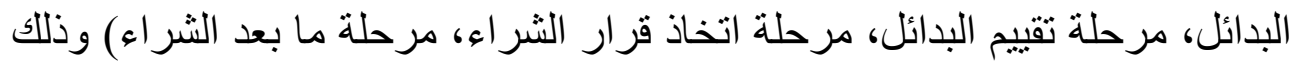

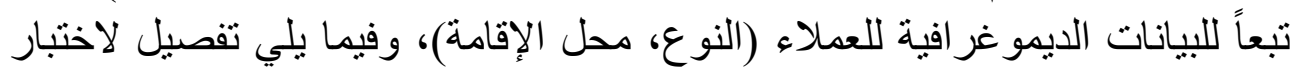

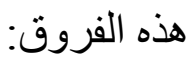




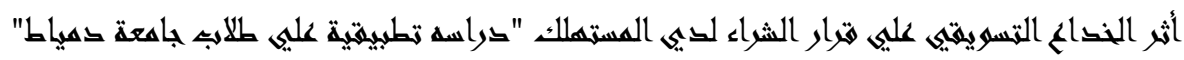

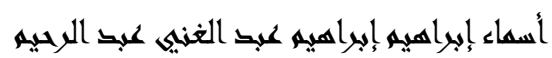

ا ـوهرية الفروق بين العملاء (من طلاب الجامعات) فيما يتعلق باستجاباتهم لأبعاد

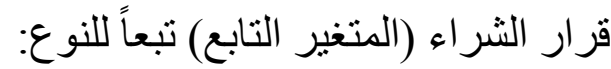

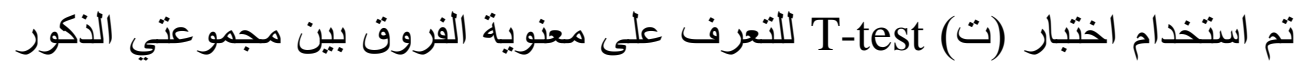

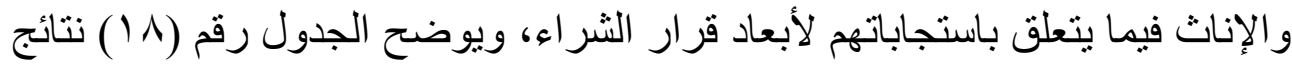
هذا الاختبار.

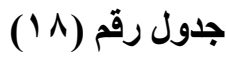

اختبار (ت) جوهرية الفروق بين استجابات الأكور والإناث لأبعاد قرار الثراء

\begin{tabular}{|c|c|c|c|c|c|c|}
\hline \multicolumn{2}{|c|}{ T-test (ختبار (ت) } & \multirow{2}{*}{ المعياري } & \multirow{2}{*}{ الحستوسي } & \multirow{2}{*}{ عداد } & \multirow[b]{2}{*}{ النوع } & \multirow[b]{2}{*}{ المتغير } \\
\hline المعنوية & قيمة T T & & & & & \\
\hline \multirow{2}{*}{$\cdot V \leqslant 0$} & \multirow{2}{*}{ •rY } & .011 & \&.rIY & 199 & أنثى & \multirow{2}{*}{ ادراك الحاجة } \\
\hline & &. .45 & $\varepsilon . r Y \wedge$ & rir & ذكر & \\
\hline \multirow{2}{*}{$\because \wedge \wedge$} & \multirow{2}{*}{. .710} & $\because 040$ & $\varepsilon . Y 90$ & 197 & أنثى & \multirow{2}{*}{ بين البدائل المقارنة } \\
\hline & & $.07 r$ & $\varepsilon . Y 91$ & rIT & ذكر & \\
\hline \multirow{2}{*}{$\cdot .7 \leq \varepsilon$} & \multirow{2}{*}{$\cdot .7 \leqslant \Gamma$} & .094 & \&.Yร. & 199 & أنثى & \multirow[t]{2}{*}{ تقييم } \\
\hline & &. .717 & $\varepsilon . Y \wedge V$ & rIT & ذكر & \\
\hline \multirow{2}{*}{. Y97 } & \multirow{2}{*}{$1 . \cdot \leq 0_{-}$} &. .710 & \&.Y०Y & 197 & أنثى & \multirow{2}{*}{ قرار الثراءة اءخاذ } \\
\hline & & $\because 074$ & \&.MIV & YIT & ذكر & \\
\hline \multirow{2}{*}{$\because$ \& } & \multirow{2}{*}{$.90 \%$ _ } & $\because .89$ & \&.rY & 197 & أنثى & \multirow{2}{*}{ مرحلة ما بعد } \\
\hline & & . & \&.MYT & rIT & ذكر & \\
\hline
\end{tabular}

المصدر: من إعداد الباحث وفقاً لنتائج التحليل الإحصائي. يتضح من الجدول رقم (1 ا ( ) ما يلي: عدم وجود فروق ذات دلالة معنوية بين استجابات الذكور و الإناث فيما يتعلق بمرحلة

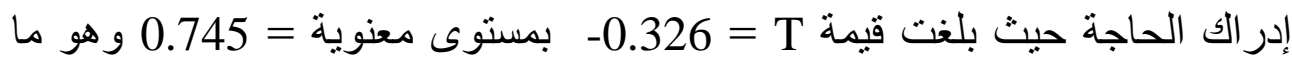
يؤكد عدم معنوية الفروق. عدم وجود فروق ذات دلالة معنوية بين استجابات الذكور و الإناث فيما يتعلق بمرحلة

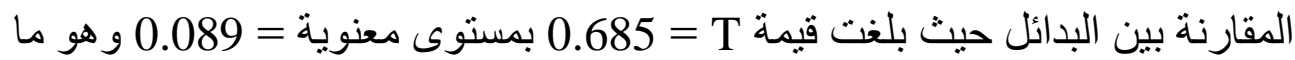
يؤكد عدم معنوية الفروق. 


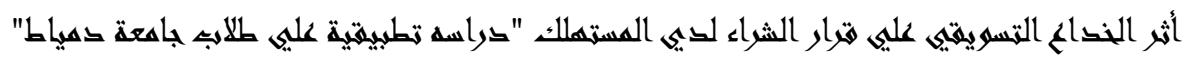

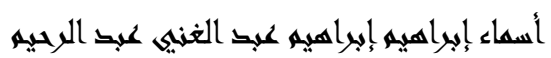

عدم وجود فروق ذات دلالة معنوية بين استجابات الذكور و الإناث فيما يتعلق بمرحلة تقييم البدائل حيث بلغت قيمة T = 0.643 بمستوى معنوية = 0.644 وهو دانه ما يؤكد عدم معنوية الفروق.

عدم وجود فروق ذات دلالة معنوية بين استجابات الذكور و الإناث فيما يتعلق بمرحلة

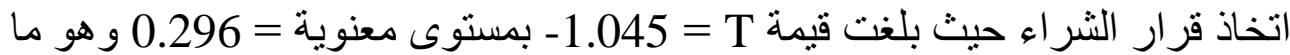
يؤكد عدم معنوية الفروق.

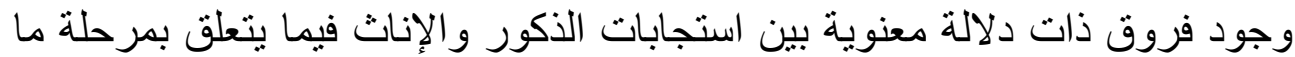

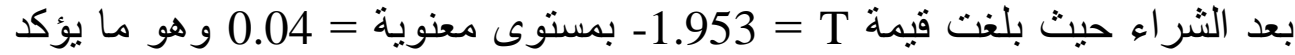
معنوية الفروق لصالح الذكور، حيث تثير فروق المتوسطات إلى أن مفردات العينة من الذكور يشعرون بعدم الرضا بعد الثر اء بشكل أكبر من الإناث.

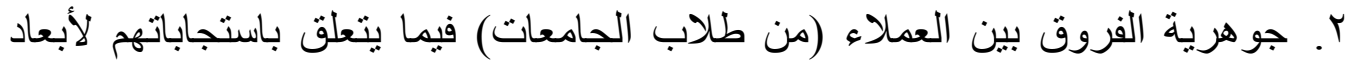

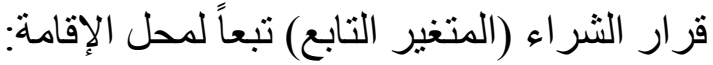
تم استخدام اختبار (ت) T-test للتعرف على معنوية الفروق بين العملاء (من طلاب التعاء

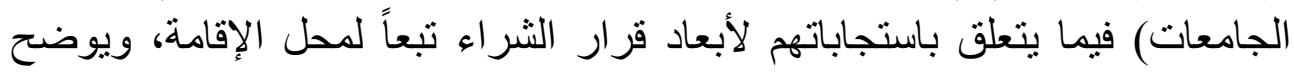
الجدول رقم (9 ( ) نتائج هذا الاختبار.

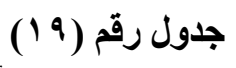

اختبار (ت) جوهرية الفروق بين استجابات العملاء لأبعاد قرار الشراء تبعاً لمحل الإقامة

\begin{tabular}{|c|c|c|c|c|c|c|}
\hline \multicolumn{2}{|c|}{ T-test اختبار (ت) } & \multirow{2}{*}{ الانعراف } & \multirow{2}{*}{ المثتوسط } & \multirow{2}{*}{ عدد المشاهدات } & \multirow{2}{*}{ النوع } & \multirow{2}{*}{ المتغير } \\
\hline مستوى المعنوية & قيمة & & & & & \\
\hline \multirow{2}{*}{.191} & \multirow{2}{*}{$1 . r q}$. & $\because \leqslant O V$ & $\varepsilon .40$ & YIN & المدينة & \multirow{2}{*}{ الدراكة } \\
\hline & & $.01 \mathrm{VV}$ & $\varepsilon . r \wedge \wedge$ & 191 & الريف & \\
\hline \multirow[b]{2}{*}{$\because \diamond \wedge \varepsilon$} & \multirow[b]{2}{*}{$1.0 \leqslant 1$} & $\because$ Orr & $\varepsilon . r \cdot V$ & YIA & المدينة & \multirow{2}{*}{ مرحلة } \\
\hline & & $\because \diamond \vee \wedge$ & $\varepsilon . Y V V$ & 191 & الريف & \\
\hline \multirow{2}{*}{$\because r_{1}$} & \multirow{2}{*}{$1.91 \varepsilon$} & $\because 09 \leq$ & $\varepsilon . Y \vee 0$ & YIA & المدينة & \multirow{2}{*}{ ترحلة } \\
\hline & &. .711 & $\varepsilon . Y V \varepsilon$ & 191 & الريف & \\
\hline
\end{tabular}




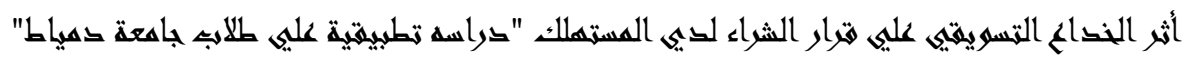

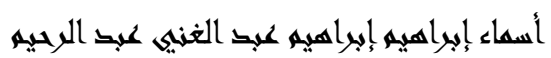

\begin{tabular}{|c|c|c|c|c|c|c|}
\hline \multirow[b]{2}{*}{$\because r \cdot r$} & \multirow[b]{2}{*}{. Orr } & $\because 0 \wedge 0$ & $\varepsilon . r \cdot Y$ & YIA & المدينة & \multirow{2}{*}{ الثخاذ قرار } \\
\hline & & $\because 09 r$ & $\varepsilon . Y V Y$ & 191 & الريف & \\
\hline \multirow{2}{*}{$\because v \otimes V$} & \multirow{2}{*}{$\cdot r \cdot q_{-}$} & $\because \leq \leqslant 1$ & \&.M & 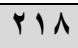 & المدينة & \multirow{2}{*}{ مرحد الثراء ماء } \\
\hline & &..$E Y V$ & $\varepsilon . r Y q$ & 191 & الريف & \\
\hline
\end{tabular}

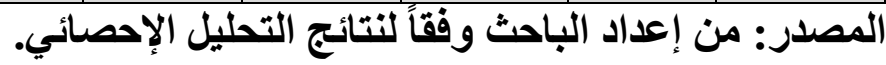

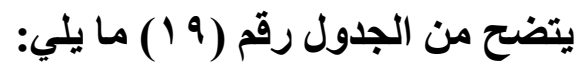
• عدم وجود فروق ذات دلالة معنوية بين استجابات كلٍ من سكان المدينة والريف المانف

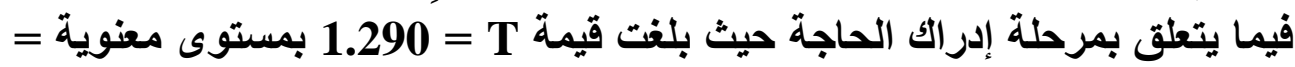
0.198 وهو ما يؤكد عدم معنوية الفروق. • عدم وجود فروق ذات دلالة معنوية بين استجابات كلٍ من سكان المدينة ولئة والريف

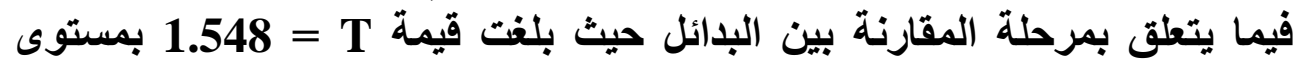
معنوية = 0.584 وهو ما يؤكد عدم معنوية الفروق.

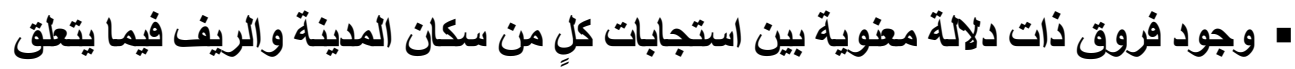

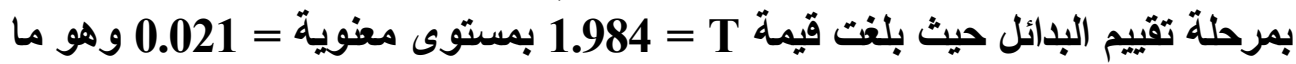

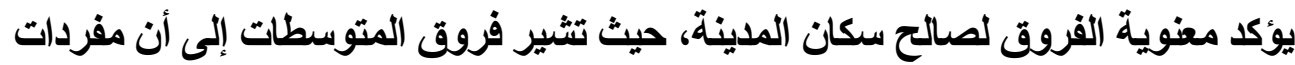

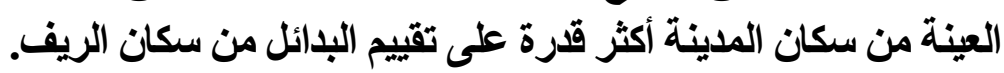

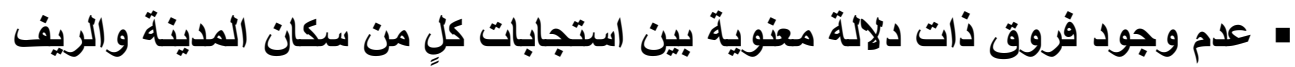

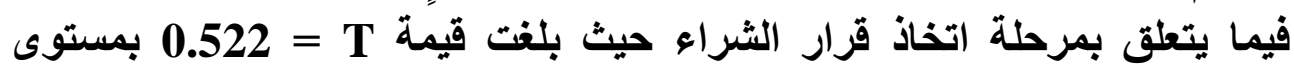
معنوية = 0.602 وهو ما يؤكد عدم معنوية الفروق.

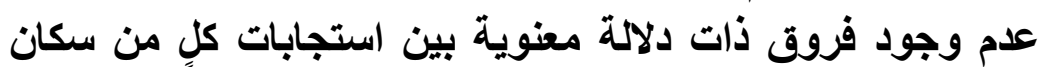

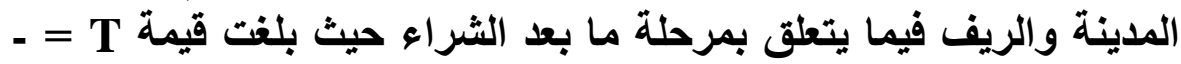
0.309 بمستوى معنوية = 0.757 وهو ما يؤكد عدم معنوية الفروق.

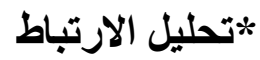
تم إجراء تحليل الارتباط للتعرف على مدى وجود علاقة ارتباط بين متغيرات

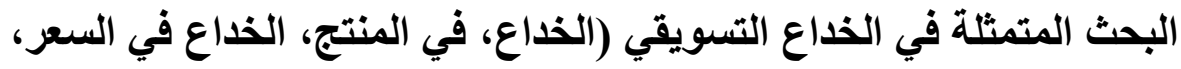




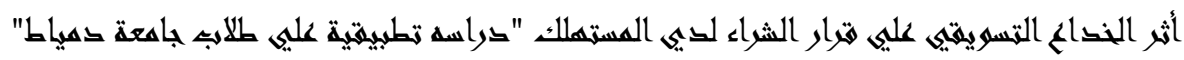

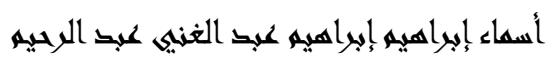

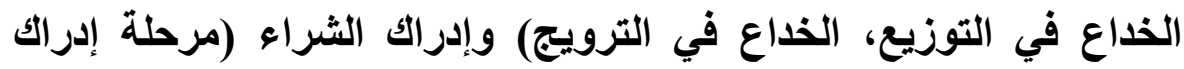

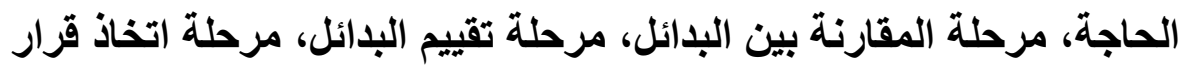

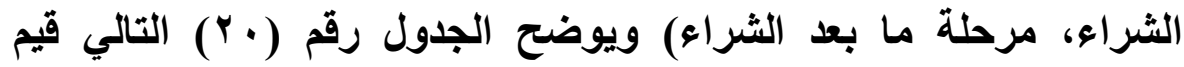
معاملات الارتباط بين متغيرات البحث. مئه

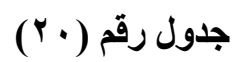

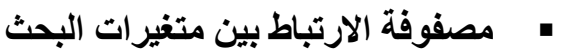

\begin{tabular}{|c|c|c|c|c|c|c|c|c|c|}
\hline ما مالشد & قرار الثراء اتخاذ & تقييم البدائل & المقارنة بين & الحرحلة & الخداع في & الخداع في & الخداع في & الخداع في & المتغيرات \\
\hline & & & & & & & & 1 & الخداع في \\
\hline & & & & & & & 1 & $\because \curlyvee \wedge \neg *$ & الخداع في \\
\hline & & & & & & 1 & $\because 11$. & .171 & الخداع في التوزيع \\
\hline & & & & & 1 & $\because r 90 *$ & $\because r \wedge \mu$ & $\because V V$ & الخداع في الترويج \\
\hline & & & & 1 & $\because \neg \diamond \wedge * *$ & • & $\because V \backslash \leq * *$ & $.70 . * *$ & الدرحلة \\
\hline & & & 1 & $\because \wedge$ Y ०** & $\because 07 . * *$ & $.0 \leqslant 0 * *$ & $\because 7 r q * *$ & $.0 r r * *$ & بين المقارنة \\
\hline & & 1 & $\because \wedge \cdot 7 * *$ & $\because 7 V \cdot * *$ & $\because 70 \wedge * *$ & $\because 719 * *$ & $\because 0 \vee 9 * *$ & $.77 . * *$ & تقيلة \\
\hline & 1 & - $\wedge \mathrm{H} \wedge * *$ & $\because V \leq \Delta * *$ & $\because 77 \leqslant * *$ & ・フフル** &. $.717 * *$ & $.7 r r * *$ & $\because V Y \backslash * *$ & اتخاذ قرحلة \\
\hline 1 & $\because \vee \wedge \mid * *$ & $\because \wedge \backslash \wedge * *$ & $\cdot \wedge \cdot \wedge * *$ &.$\neg \wedge \vee * *$ &. $.7 .0 * *$ & $.00 \vee * *$ & $. .7 \leqslant 7 * *$ & $\bullet \vee 1 . * *$ & مرحد الشرة ماء \\
\hline
\end{tabular}

المصدر: من إعداد الباحث وفقاً لنتائج التحليل الإحصائي.

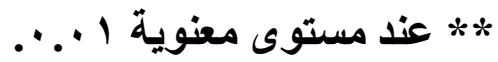

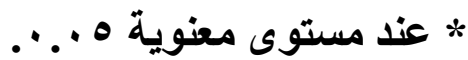




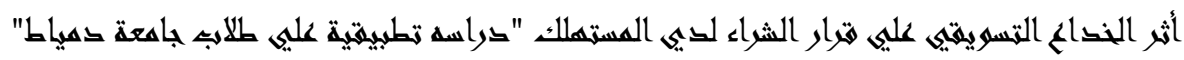

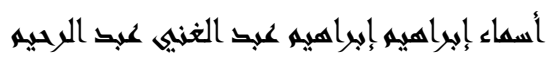

يتضح من الجدول السابق أن جميع معاملات الارتباط بين المتغيرات الفرعية

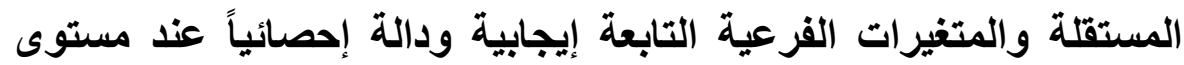

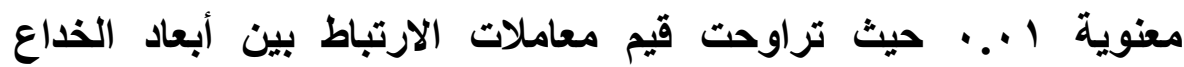

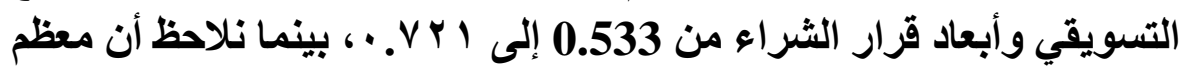

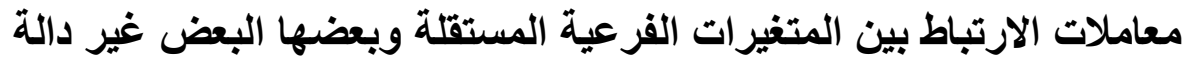

إحصائياً. - حدود البحث :

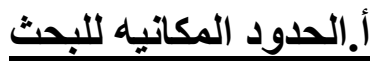

تم توزيع إستمارات الإستقصاء الخاصة بالطلاب في جامعة دمياط وفي كلياتها

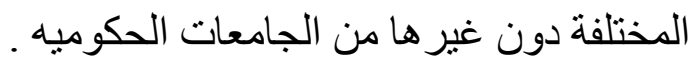

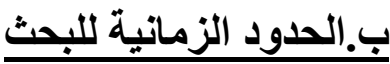

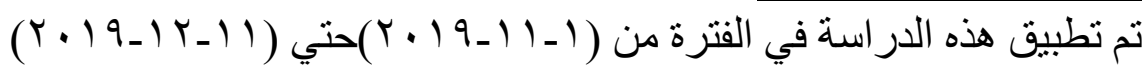

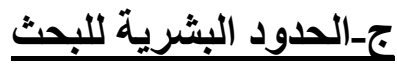
تم تطبيق هذه الدراسة علي طلاب مرحلة البكالوريوس و الليسانس دون غير هم من من

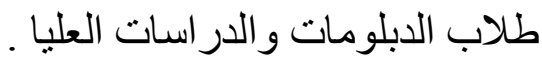
النتائج والتوصيات : التودات

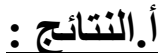
تبين من خلال تحليل إستجابات طلاب الجامعه مايلي :

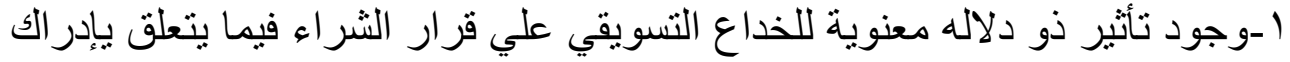
الحاجه حيث تبين من خلال نتائج الفروض الفرعيه صحة هذا الفرض جزئئيا وذللك علي النحو التالي : ماجه -وجود تأثثر ذو دلاله معنويه للخداع في المنتج علي إدر الك الحاجة .

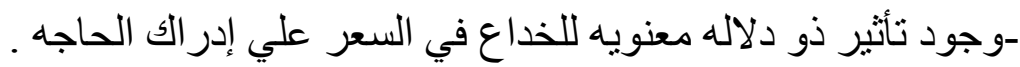

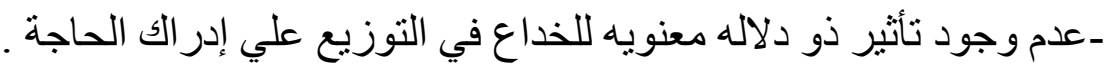
-و جود تأثيرذو دلاله معنويه للخداع في الترويج علي دلإله إدر الك الحاجه . 


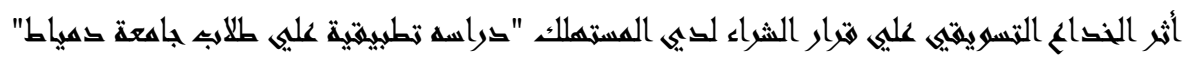

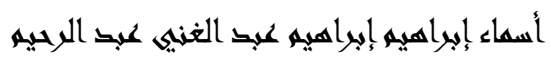

r-وجود تأثير ذو دلاله معنوية للخداع التسويقي علي قرار الثراء فيما يتعلق

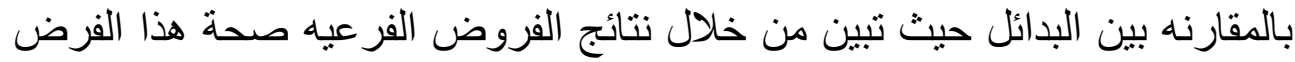

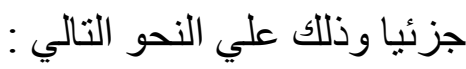

-وجود نأثير ذو دلاله معنويه للخداع في المنتج علي المقارنه بين البدائل .

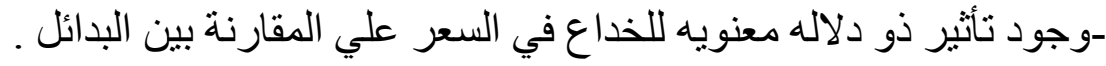

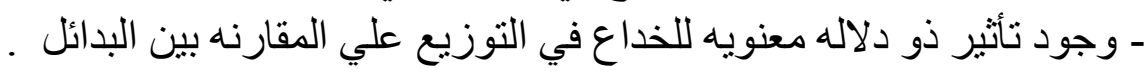

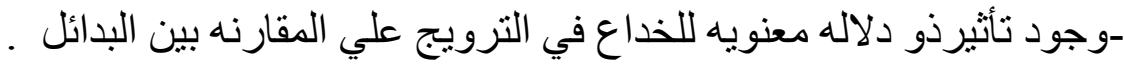

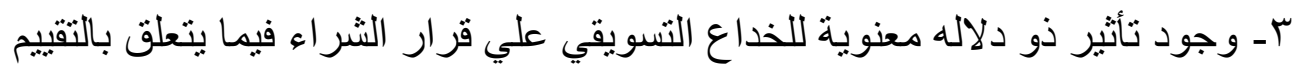
بين البدائل حيث تبين من خلال نتائج الفروض الفروعيه دئ صحة هذا الفرض جزئيا وذللك علي النحو التالي :

ـ عدم وجود تأثير ذو دلاله معنويه للخداع في المنتج علي المقارنه بين البدائل .

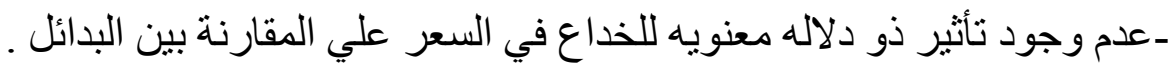

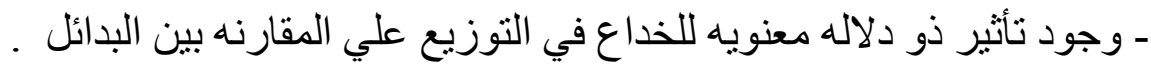

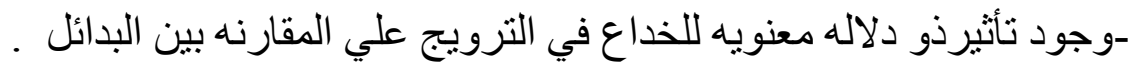

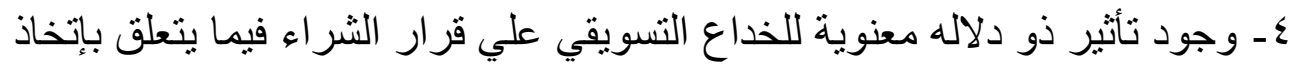

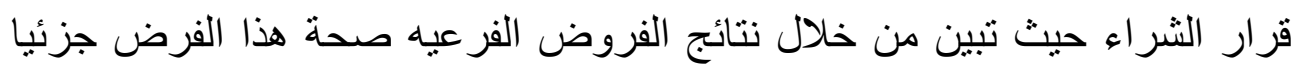
وذللك علي النحو التالي :

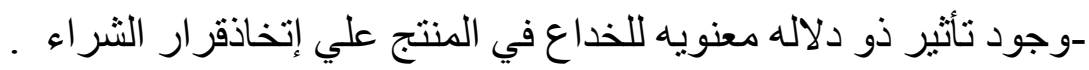

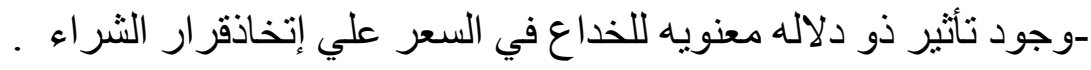

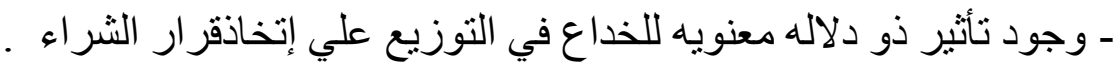

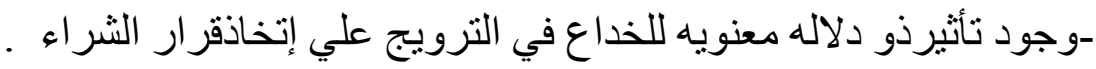

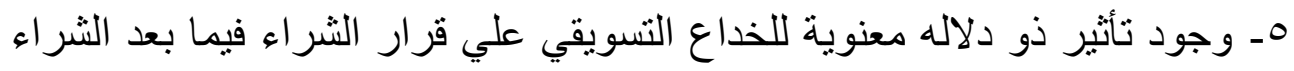
حيث تبين من خلال نتائج الفروض الفر عيه صحة هذا الفيه الفرض جزئيا وذللك علي النحو التالي : -وجود تأثثير ذو دلاله معنويه للخداع في المنتج علي ما بعد الثراء. 


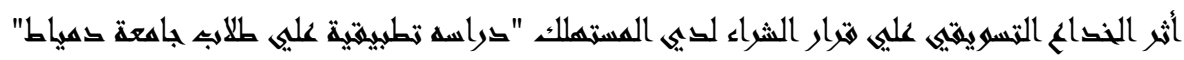

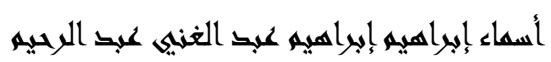

-وجود تأثثير ذو دلاله معنويه للخداع في السعر علي ما بعد الثراء.

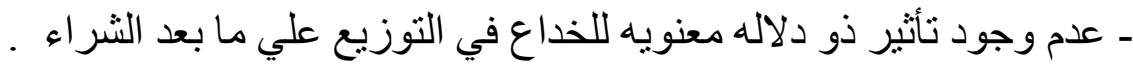

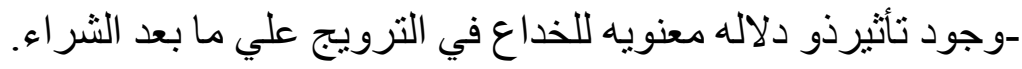

ب-التوصيات : بودنون

ا ـضرورة توعية أصحاب مطاعم الوجبات السريعه بكيفيه الحفاظ علي المنتجات

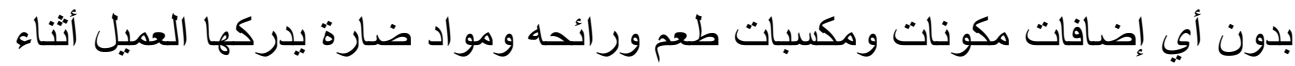

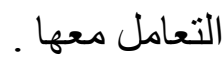
r- لابد من إيجاد تفسير واضح وصريح للزيادة التي تحدث في الأسعار داخل

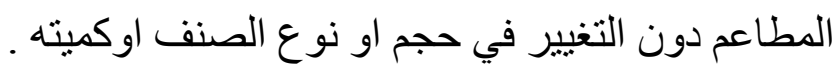

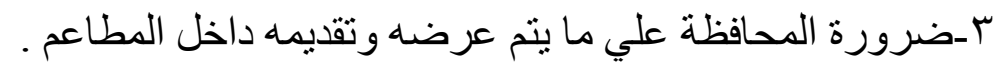

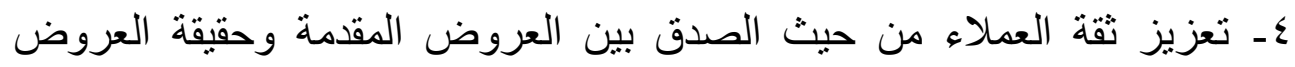
الو همية المقدمة. 0ـ العمل علي اشباع احتياجات ورغبات العملاء داخل المطاعم . 7 ـ العمل علي تجديد ثقة العميل لنفس المطعم و الذي كان له فيها تجارب الجي سلبية سابقة .

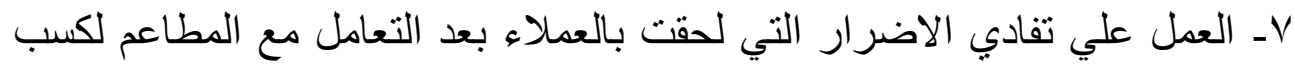
ثقتهم مرة اخري. 1ـ ضرورة كسب ثقة العملاء بتوفير جو مناسب لكسب رضاهم بعد التجارب السابقة مع هذه المطاعم.

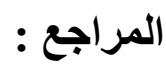
اولا:المراجع العربية: المئية الهنداوي،ونس عبد الكريم ،حسونه،عبد الباسط إبراهيم ،أخرون،(· • • ؟)،"تقييم العلاقة بين تبني

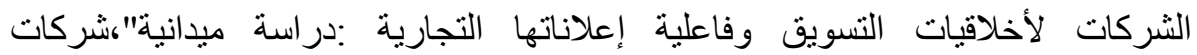

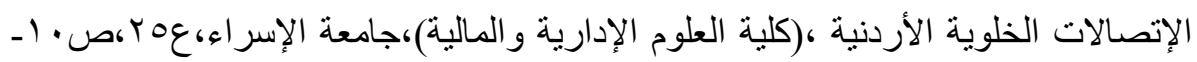
I

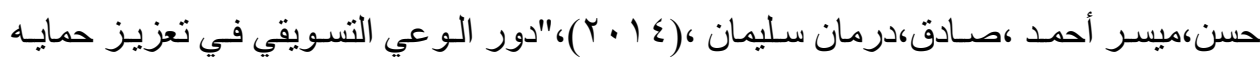

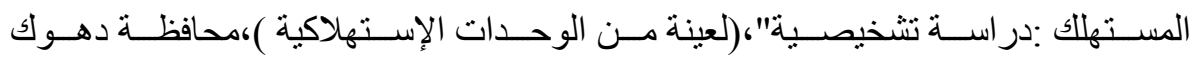




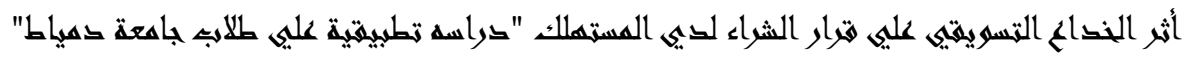

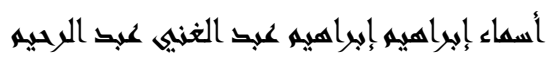

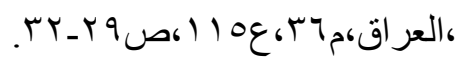

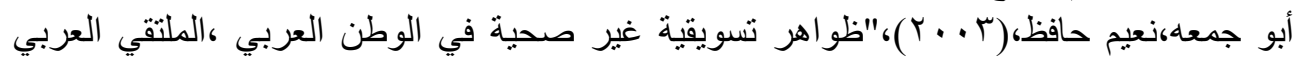

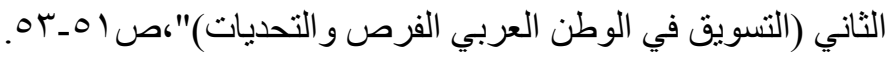

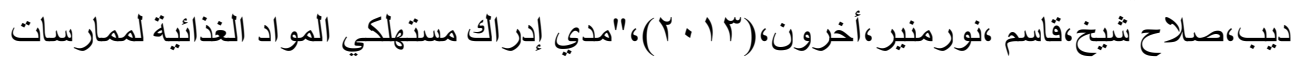
الغش و الخداع التسويقي :دراسة ميدانية في مدينة اللاذقية "،مجلة جامعة تشرين للبحوث

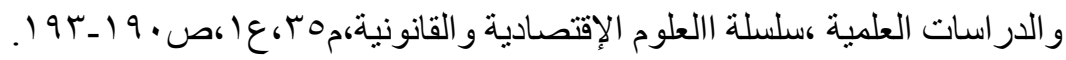

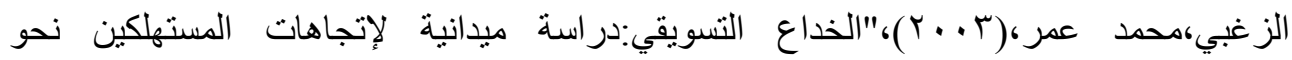
الممارسات اللأخلاقية في التسويق في مدينة أربد"،رسالة ماجستير،جامعة اليرموك،كلية

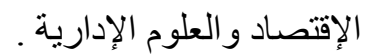

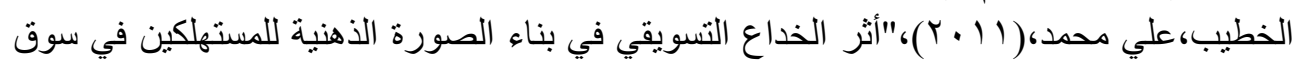

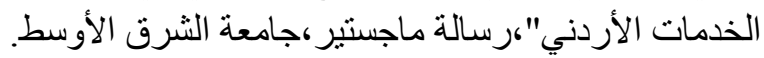
أبوجمعه،نعيم حافظ ،(Y . . . (Y)،"الخداع التسوبقي في الوطن العربي"،ملتقي التسويق في الوطن

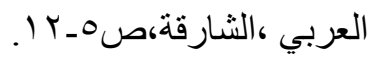

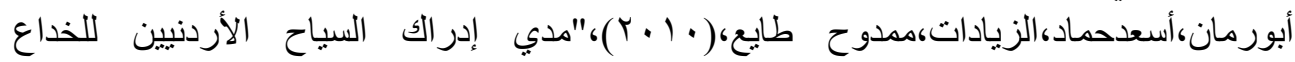

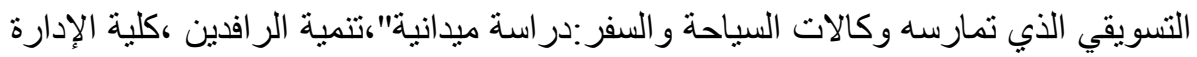

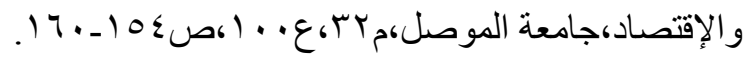

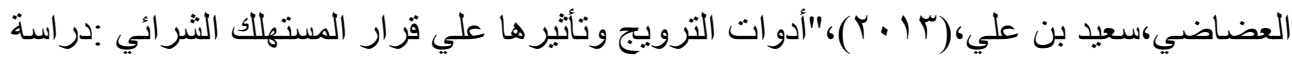

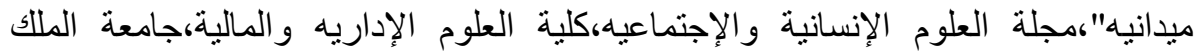

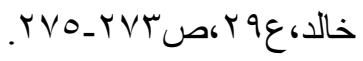

أبوزنط،مفيد،(r ( • Y)،الدور الرقابي لجمعية حماية المستهلك الفلسطيني علي السلع الإستهلاكية في

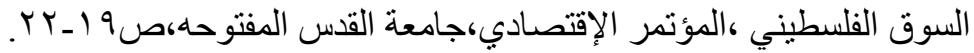

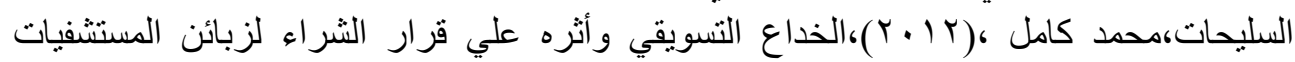
الخاصه،رسالة ماجستير ،جامعة عمان العربية،كلية الأعمال.

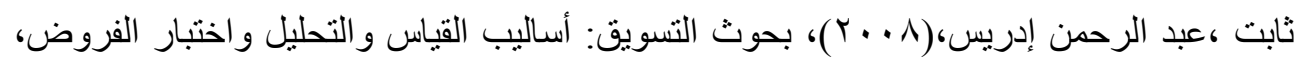
الدار الجامعية، الأسكندرية، الرجن، 


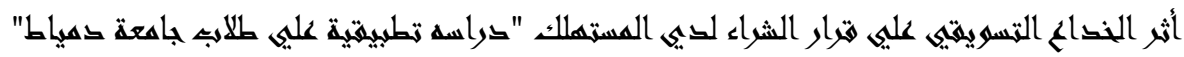

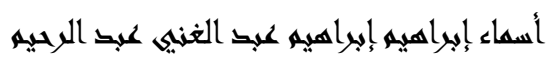

Kotler,p.,and keller,k.1.,(2016)."Marketing management". Durkin,s.,(2015),"Deceptive marketing practices:How some consumers benefit when others are deceived ",Economics committee News letter,14(1),3-15.

Aladwan,k.,andHersh,A.,(2014)"Touristsperceive Marketingdeception through the promotional mix",Business Management Dynamics,3(12),21-35

Riquelme,I.p.,Roman,s., and Iacobucci,D.,(2016),"consumers perceptions of online and ofline retailer deception amoderated mediation analysis, journal of interactive Marketing ,35,16-26.

Wijaya,G.,D.,Silalahi,R., and Astuti,R.,(2015), Marketing Strategy Based on Marketing Mix Influence on Purchasing Decisions of Malang Apples Consumers at Giant Olympic Garden Mall (MOG), Malang City, East Java Province, Indonesia,68-71.

Bessouh,N.,and Belkhir,D.,(2018), The Effect of Mood on Impulse Buying Behavior - Case of Algerian Buyers, Austin Journal of Business Administration and Management,2(1),2-4.

Hastuti Moh,N.,Rommy,A.,etal.,(2018), Effect Of Brand Image And Price Perception On Purchase Decision, IOSR Journal of Business and Management (IOSR-JBM),20(8),76-79.

Gaber,H.,Salem,K., and etal.,(2018), THE EFFECT OF MARKETING DECEPTION ON CONSUMER BUYING DECISION ON FACEBOOK. AN EMPIRICAL STUDY ON UNIVERSITY STUDENTS IN LIBYA, European Journal of Business and Innovation Research,6(3), 12-18.

Khalifa,f.,b,Agha,A.,(2017), The effect of promotion on the purchasing decision of the consumer in the Kurdistan region,v2,(3). 